九州大学学術情報リポジトリ

Kyushu University Institutional Repository

\title{
Geology of the Kali Gandaki Supergroup of the Lesser Himalayas in Nepal
}

Sakai, Harutaka

Faculty of Science, Kyushu University

https://doi.org/10.5109/1546320

出版情報：九州大學理學部紀要：Series D, Geology. 25 (3)，pp.337-397，1985-02-25. Faculty of Science, Kyushu University バージョン：

権利関係 : 
Mem. Fac. Sci., Kyushu Univ., Ser. D, Geol., Vol. XXV, No. 3, pp. 337-397, text figs. 1-19, table 1, plates 42-49, February 25, 1985

\title{
Geology of the Kali Gandaki Supergroup of the Lesser Himalayas in Nepal
}

\author{
Harutaka SAKAI
}

\begin{abstract}
The Kali Gandaki Supergroup is extensively distributed in the Mahabharat Range and the Midland of the Lesser Himalayas in western Central Nepal. It is a thick sequence attaining more than $10 \mathrm{~km}$ in thickness and ranging in age from Late Precambrian to early Palaeozoic, and is unconformably overlain by the Tansen Group of Gondwana rocks. There is no stratigraphic break throughout the whole sequence.

The Kali Gandaki Supergroup is divided into three groups. The Lower Group consists of the thick, monotonous, predominantly gritty phyllite and phyllite Andhi Formation and the overlying, strongly rippled and cross-bedded Naudanda Quartzite. Metabasites are sporadically interbedded in the Naudanda Quartzite.

The Middle Group is composed of five conformable formations. The lowest Heklang Formation comprises monotonous, light-green phyllite with subordinate limestone and marl beds. The Virkot Formation represents cyclic sedimentation of sand dune and ephemeral lake and fluvial deposits that are characterized by reddish-purple shale and quartzite with sun cracks and some stromatolite beds. The Lower and Middle Members of the Chappani Formation comprise black, light-green and pink, calcareous laminated slate with many thin interbeds of column-shaped Kussiella and Collenia-type stromatolites. They are the deposits in a lagoonal environment. The Upper Member is made up of quartzite and reddish-purple and light-green shale with some beds of shale-pebble conglomerate. Sun cracks are common in shale beds. The Khoraidi Formation is unique in having a large number of stromatolite biostromes which totally attain $300 \mathrm{~m}$ in thickness. The stromatolites are domed to subspherical, and are dolomitic. Oolite, sandstone and shale rhythmite, and quartzose sandstone with abundant gypsum pseudomorphs are interbedded. This formation is referred to as the deposits in the intertidal zone under arid climate conditions. The Saidi Khola Formation consists of coarsely to thinly interlayered sandstone and shale with many burrows by bioturbation, and is interpreted to have been deposited on shallow subtidal to intertidal flats.

The Upper Group consists of two formations; the Ramdighat of predominantly calcareous, varicoloured slate and the Kerabari largely of thick, monotonous, platy bedded dolomite and limestone. The Ramdighat indicates the deposition in the lagoonal environment and the Kerabari was deposited in the shallow shelf to intertidal environments.

The Lesser Himalayas in the study area is structurally divided into two belts, a complexly folded outer belt and block-faulted inner belt by the active right-lateral Bari Gad Fault. The outer belt forms the Mahabharat Range to the north of the Main Boundary Thrust and the inner belt is expressed by the depressed topography of the Midland.
\end{abstract}

The outer belt is subdivided into three structural units disposed from south

Manuscript received September 20, 1984 
to north; the Tansen Synclinorium, Angha Khola Recumbent Fold Belt and Khoraidi Fold Belt. The Tansen Synclinorium is largely occupied by the Tansen Group of Gondwanas and Tertiary rocks, and is overlain by the Palpa Klippe with intensely deformed melanges along the sole thrust. The Kali Gandaki Supergroup of the Angha Khola Belt wholly exhibits a reversed stratigraphy. On the basis of consistent Z-shaped asymmetric folds of various sizes and the bedding-cleavage relationship, it was confirmed to form an inverted limb of a huge recumbent fold. In the Khoraidi Belt the supergroup shows northerly verging isoclinal folds.

The southern part of the inner belt is segmented by longitudinal highangle faults with the component of great vertical displacements more than $1000 \mathrm{~m}$. Each block is usually occupied by a single or two formations and forms a broad open fold. The Lower Group thrusts upon the upper groups along the Phalebas Thrust in the southern front of the northern part.

The juxtaposition of the strongly folded and thrust outer belt and the block-faulted inner belt in the Lesser Himalayas can be explained by differences of stress fields, compressional in the frontal part and tensional on the rear side of a large scale thrust-sheet associated with the Main Boundary Thrust. These structures are considered to have been formed after main activity of the Main Central Thrust.

\section{Contents}

Page

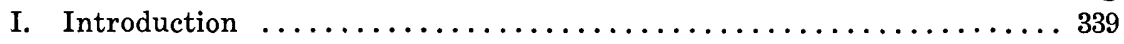

II. Geologic Setting and General Geology $\ldots \ldots \ldots \ldots \ldots \ldots \ldots \ldots \ldots . \ldots \ldots 40$

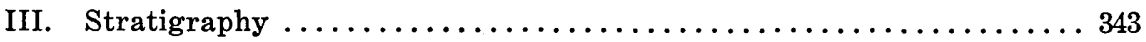

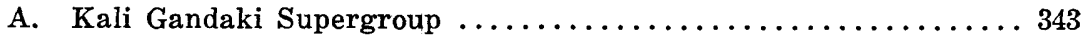

B. Lower Kali Gandaki Group ......................... 344

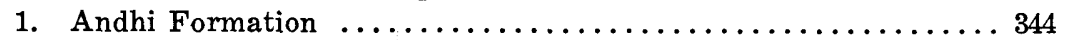

2. Naudanda Quartzite ............................... 345

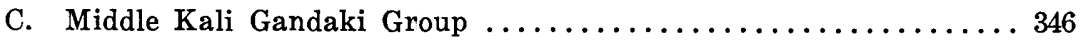

1. Heklang Formation $\ldots \ldots \ldots \ldots \ldots \ldots \ldots \ldots \ldots \ldots \ldots, \ldots \ldots \ldots$

2. Virkot Formation $\ldots \ldots \ldots \ldots \ldots \ldots \ldots \ldots \ldots \ldots \ldots \ldots \ldots \ldots \ldots \ldots, \ldots \ldots \ldots$

3. Chappani Formation ............................ 352

4. Khoraidi Formation $\ldots \ldots \ldots \ldots \ldots \ldots \ldots \ldots \ldots \ldots, \ldots \ldots \ldots, \ldots \ldots \ldots$

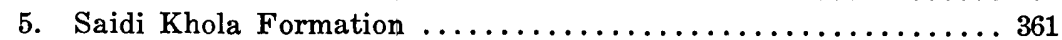

D. Upper Kali Gandaki Group ...................... 364

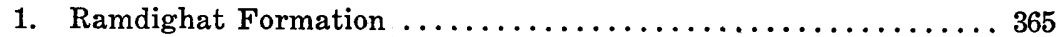

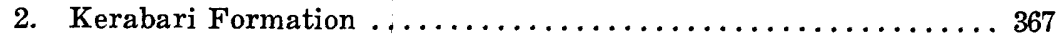

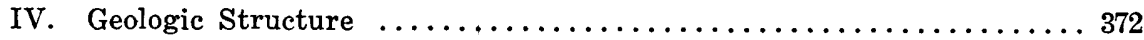

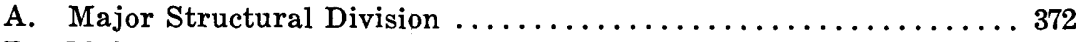

B. Major Boundary Faults ............................... 374

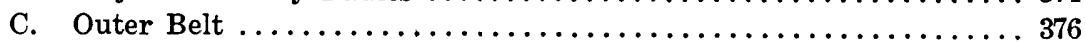

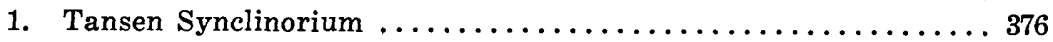

2. Angha Khola Recumbent-Fold Belt .................. 378

3. Palpa Klippe ............................... 382

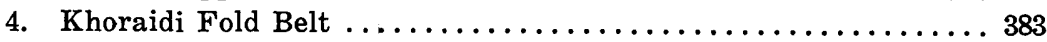

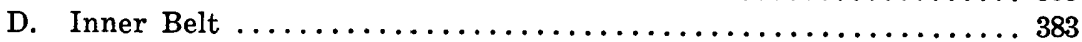

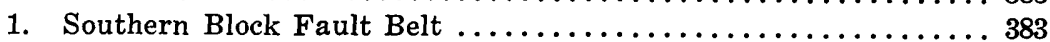

2. Northern area near the Phalebas Thrust ................ 384

V. Discussion ....................................... 384

A. Geologic Age and Correlation $\ldots \ldots \ldots \ldots \ldots \ldots \ldots \ldots \ldots \ldots \ldots$ 
B. Sedimentary Environments and Depositional History . . . . . . . 389

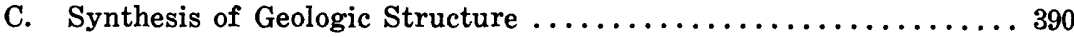

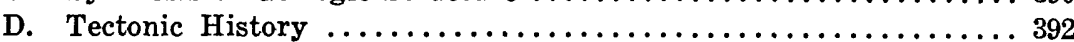

Acknowledgements ................................ 394

References .................................... 394

\section{Introduction}

The Lesser Himalayas stretching over $1500 \mathrm{~km}$ from Himachal Pradesh to Bhutan and lying between the Great Himalayas and the Gangetic Plain is made up of a highly deformed, thick pile of clastic and carbonate rocks. The stratigraphy and sedimentary facies of these rocks afford the key to solve the depositional and tectonic history of the Indian Subcontinent before collision of it with the Eurasia. Structural analyses of these rocks also give informations on the orogenic development of the Himalayas in the progression of the collision.

The geology of the Lesser Himalayas has been extensively clarified by many workers particularly in the Kumaon and Simla-Garhwal regions. However, with the advance of the studies in other regions including Nepal, futile controversy or unsolvable disagreement on the stratigraphy and correlation between and among the rocks of distant places has arised, as aptly expressed by VALDIYA (1980-a) as "a tangled confusion" and by STöckLIN (1980) as "a hopeless confusion". This came largely from careless application of stratigraphic terminology to rocks of distant places based on easy correlation simply relying upon apparent lithologic similarities, and from proposal of new unit-names without designation of type sections and clear definitions of those units.

As most of the Lesser Himalayan rocks is unfortunately scanty of fossils, practicable at present for linking the rocks of distant places is only the lithostratigraphic comparison (not stratigraphic correlation). To avoid the aggravation of such sort of confusion as mentioned above, it is fundamentally necessary to make systematic and detailed large-scale mapping and to establish the litho-

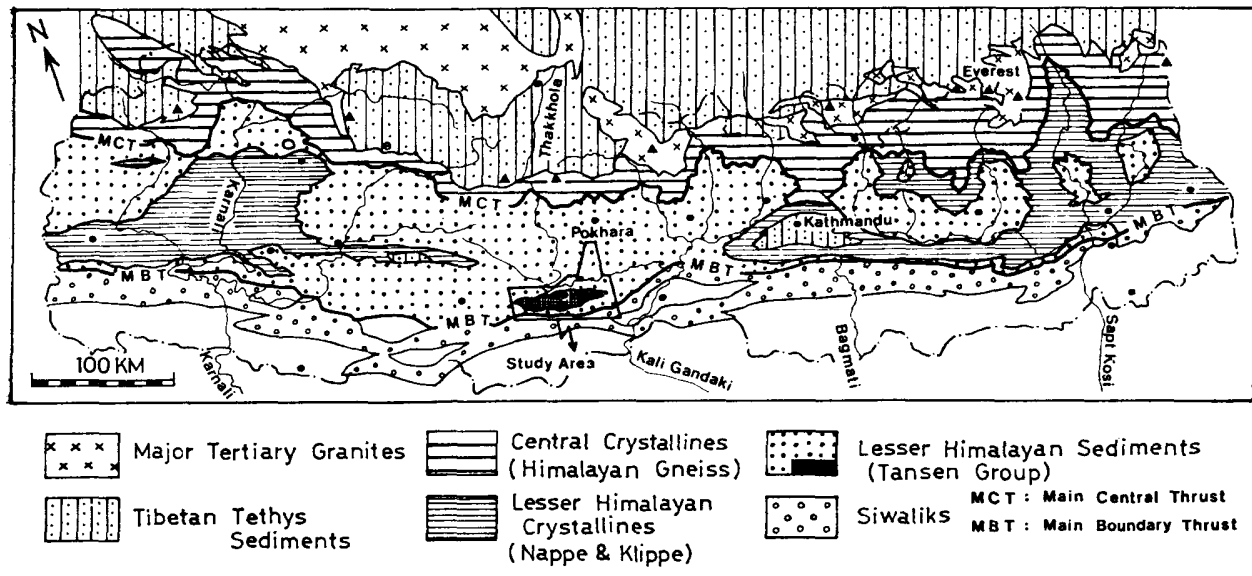

Fig. 1. Geological zonation of Nepal Himalayas and location of study area. Modified from STöckLIN (1980). 
stratigraphic sequence with appropriate descriptions of the defined rock-units.

I had an opportunity to work in the Tribhuvan University in Nepal for three years (1980-1983) as a member of Japan Overseas Cooperation Volunteers (JOCV). While I was free from the teaching work, I was engaged in the study of the geology of the Tansen area and the northerly adjacent Kali Gandaki river area. The field survey was made mostly along the streams on the scale of $1: 5000$, and the obtained data were compiled on the topographic map of $1: 63,360$. The investigated area covers 1500 square kilometers. The geology of the 'l'ansen area which consists largely of the Gondwanas and post-Gondwanas was already reported (SAKAI, 1983, 1984). This paper is the second major part of the results in this series of research work made in the later half of the period of my stay in Nepal, and deals with the stratigraphy, depositional facies and geologic structures of the Kali Gandaki Supergroup comprised mostly of pre-Gondwana series. in the Kali Gandaki river area.

\section{Geologic Setting and General Geology}

The Lesser Himalayas in Nepal is separated by the Main Boundary Thrust (MBT) from the sub-Himalayan Siwalik belt consisting of Neogene postorogenic rocks (Figs. 1 and 4), and is physiographically divided into the Mahabharat Range, which occupies the area between the MBT and the Kali Gandaki river, and the Midland zone. The study area includes the Mahabharat Range and the southern sector of the Midland zone (Fig. 2). The Lesser Himalayas is made up of a thick sequence more than $10 \mathrm{~km}$ of non- to weakly metamorphosed sedimentary rocks which range in age from Precambrian to Tertiary. In the western and eastern Nepal, these rocks are extensively covered with nappes of the Lesser Himalayan Crystallines (Fig. 1), and are exposed as fensters. The crystalline klippe of the western Nepal is connected with the Almora Klippe in the Kumaon Himalaya, India (VALDrYA, 1980-a). Structurally complex, unfossiliferous and poor outcrop conditions of the Lesser Himalayas impede progress of geologic studies of this zone.

The Lesser Himalayan rocks are bounded by the Central Crystallines with the Main Central Thrust (MCT) on the north, which marks a distinct knick point as shown in Fig. 18. The Central Crystallines consists of a 5 to $10 \mathrm{~km}$ thick slab of gneiss and associated metasedimentary rocks, and gently dip north. The overlying Tibetan Tethys sedimentary rocks comprise a more than $10 \mathrm{~km}$ thick, richly fossiliferous sequence ranging in age from Cambrian to Tertiary (GANSSER, 1964; BORDET et al., 1971). They are extensively distributed in Tibet far beyond the Nepal-China border, and are interrupted by the Indus-Tsangpo ophiolite zone on the north. Both the Tibetan Tethys sedimentary rocks and the Central Crystallines are intruded by Tertiary granites.

The Lesser Himalayas in India has been divided into two belts; a narrow outer (southern) belt and broad inner (northern) belt. These divisions can be applied to the Lesser Himalayas in Nepal in the area where the klippe of the Lesser Himalayan Crystallines covers the Lesser Himalayan sedimentary rocks (Fig. 1). Namely, the area on the south of the Lesser Himalayan Crystallines 
can be called the outer belt and that on the north the inner belt. However, it is uneasy to distinguish the two belts in the area having no crystalline covers, as in the study area, that is the Tansen-Syangja area. The divisions in question, however, roughly correspond to the aforementioned physiographic division; the outer belt to the Mahabharat Range, the inner belt to the Midland zone. These two belts are separated from each other by the WNW-ESE trending Bari Gad Fault in the study area. Therefore I designate the area between the MBT and the Bari Gad Fault as the outer belt and the area on the north side as the inner belt. The outer belt is characterized by a complex schuppen structure due to intense folding and thrust faulting, while the inner belt shows a much simpler structure with broad, open folds and block faults, and forms a depressed topography of the Midland.

The area investigated includes both the outer and inner belts (Figs. 1 and 2). Many contributions to the geology of western Central Nepal including the study area have been published (HAGEN, 1969; FUCHS and Frank, 1970; Frank and FUCHS, 1970; SINGH, 1973; SAKo et al., 1973; OHta et al., 1973; REMY, 1975; Sharma, 1977, 1980; FuChs, 1980; MASCle, 1980; Arita et al., 1982; ARITA and YOSHIDA, 1982, etc.). These pioneering surveys mostly covered vast

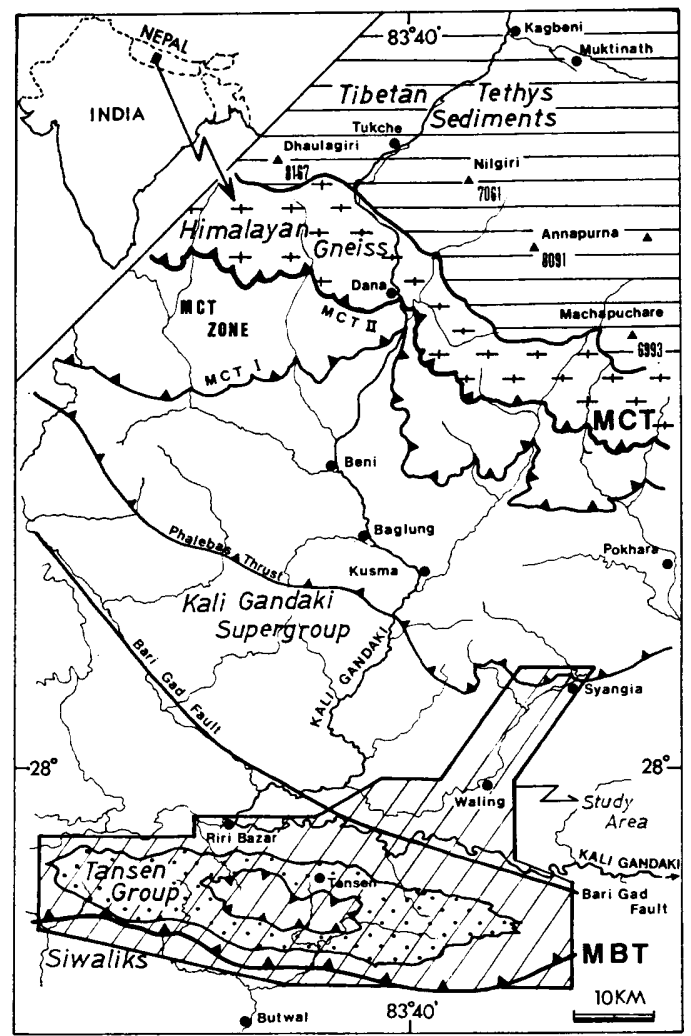

Fig. 2. Geological outline map of western Central Nepal to show location of study area (shaded). 
areas and are mainly concerned with the distribution of major lithologic units and regional-scale tectonic divisions and geologic structures. These works have greatly increased knowledge of the complex stratigraphy and structure of the Lesser Himalayas in Nepal.

The Lesser Himalayan rocks of the study area can be grouped into two major stratigraphic units; the Tansen Group and the Kali Gandaki Supergroup. The Tansen Group consists of the Gondwana and post-Gondwana rocks, which are made up mainly of clastic sediments ranging in age from late Carboniferous to early Miocene. The group is separated from the underlying Kali Gandaki Supergroup by a distinct disconformity (SAKAI, 1983). It is mostly distributed within the Tansen Synclinorium in the outer belt, but small exposures of the group are also found in the inner belt (Fig. 4). The stratigraphy and geologic structure of the Tansen Group were already described in my previous paper (SAKAI, 1983).

The underlying Kali Gandaki Supergroup is a major constituent of the Lesser Himalayas in the western Central Nepal. It is made up of a $10-\mathrm{km}$ thick sequence of quartzite, dolomite, limestone, varicoloured calcareous slate and phyllite which were mainly deposited under arid climates in shoreline environments. Stromatolites and carbonaceous organic remains commonly occur, but no other fossils significant for age determination have been found. The supergroup is lithostratigraphically comparable with the sequence from the Rautgara Formation to the Mandhali Formation in Kumaon (VALdrYA, 1980-a,-b), the Vindhyans in the Indian Shield (GANSSER, 1964), and the Nawakot Complex of the Kathmandu area in the Central Nepal (STöcKLIN, 1980), which have hitherto been regarded as the Precambrian.

The Kali Gandaki Supergroup is divided into three groups. The Lower Group is largely distributed in the area between the Main Central Thrust and Phalebas Thrust in the inner belt, and thrusts upon the Middle and Upper Groups along the Phalebas Thrust (Figs. 2 and 14). The lowest Andhi Formation, which is a correlative of the Kuncha Formation, the lowest part of the Nawakot Complex, is however, narrowly distributed on the southern border of the inner belt along the Bari Gad Fault (Fig. 4).

The Middle and Upper Groups are distributed in the area between the Phalebas Thrust and Main Boundary Thrust (Figs. 2 and 14). These groups form a set of huge Recumbent Fold and the Tansen Synclinorium of the north of the MBT (Figs. 3 and 14). The sequence showing a reversed stratigraphy is widely distributed in the northern area along the Angha Khola valley (Fig. 4). The normal sequence of the groups is observed only in the southern limb of the Tansen Synclinorium, and the exposures along the upper reaches of the Nisti Khola in the eastern end of the study area (Fig. 4) are designated as the type section of the groups. The Middle Group overthrusts onto the Tansen Group in the central part of the Synclinorium and forms the Palpa Klippe (SAKAI, 1983, figs. 2, 4; Fig. 14 in this paper). On the contrary, to the north of the Bari Gad Fault, the Middle and Upper Groups exhibit a gentler structure, and are topographically depressed by longitudinal, high-angle faults with great vertical displacements. The Bari Gad Fault running along and near the Kali 


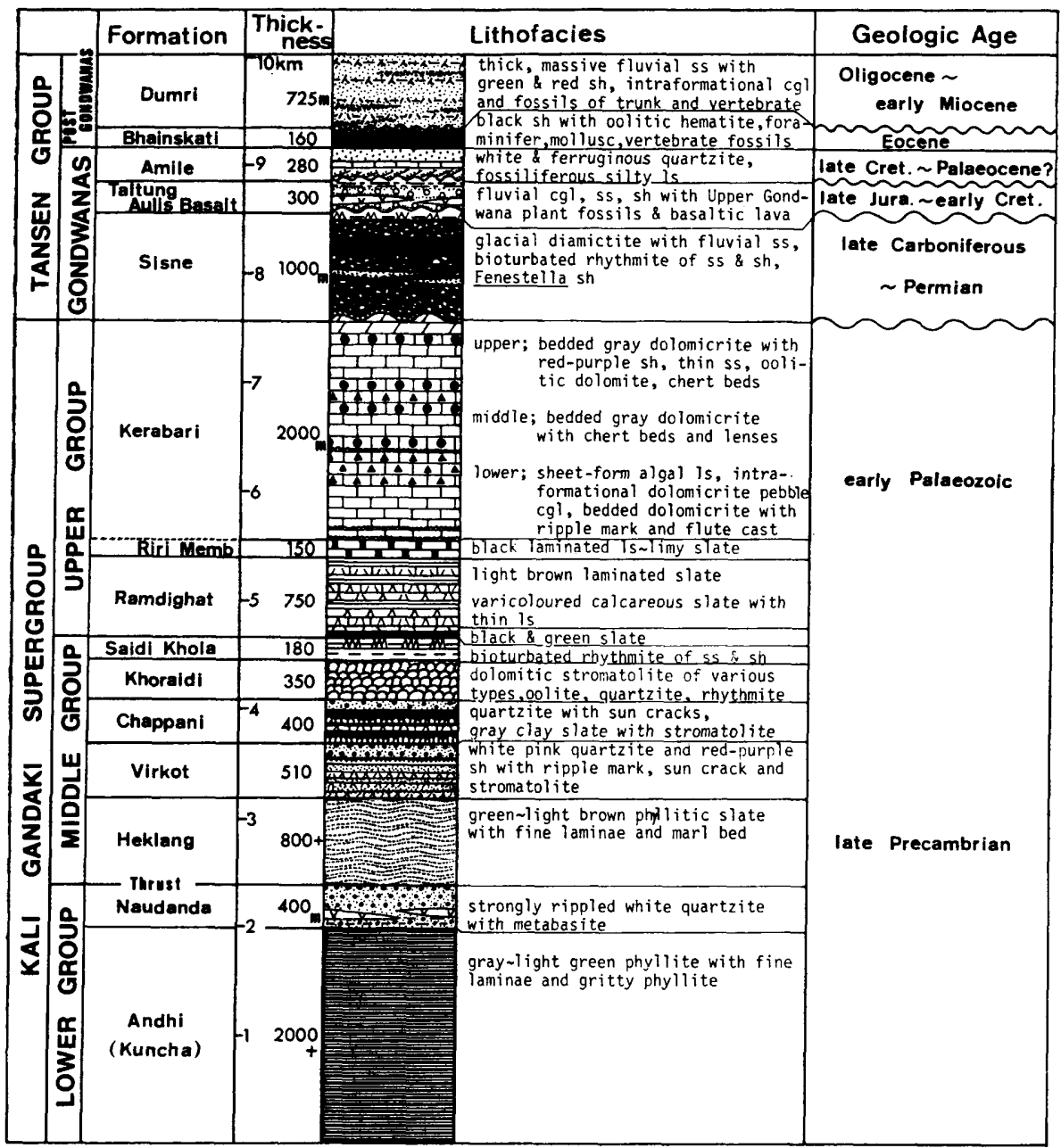

Fig. 3. Generalized lithostratigraphic section of Kali Gandaki Supergroup and Tansen Group in outer belt of Lesser Himalayas in western Central Nepal.

Gandaki river is an active fault with a component of right-lateral movement (Fig. 4; NAKATA et al., 1984).

\section{Stratigraphy}

\section{A. Kali Gandaki Supergroup}

The pre-Gondwana rocks of the study area are herein named the Kali Gandaki Supergroup. The supergroup is divided into three groups; the Lower, Middle and Upper Groups (Fig. 3). The Lower Group is a monotonous, thick sequence of predominantly argillite and argillaceous gritstone with lesser amounts of quartzite and meta-basic rocks. The Middle is an extremely varied sequence composed of quartzite, dolomite, limestone and phyllitic slate. The Upper is made up of thick dolomite, limestone and varicoloured calcareous slate. 
The Lower Group is separated from the overlying groups by a thrust and faults in the study area (Figs. 4 and 5), No remarkable depositional interruption is found in the Lower Group and throughout the Middle and Upper Groups. The lower limit is unknown, and the upper limit is placed at the exposed top of the Kerabari Formation.

In my previous paper (SAKAI, 1983, 1984), I gave brief preliminary notes on the stratigraphy and lithology of the Kali Gandaki Group, and divided the group into the Angha Khola Formation below and the Kerabari Formation above. However, as the group is a thick series over $10 \mathrm{~km}$ and ranges in age probably from Precambrian to early Palaeozoic, the rank of the formerly given lithostratigraphic units including members is raised up in this paper as shown in Fig. 3. In addition the name Angha Khola Formation is changed to the Middle and Upper Kali Gandaki Groups, because the formation in the Angha Khola is overturned and structurally complex, thus is not suitable as the type section.

\section{B. The Lower Kali Gandaki Group}

The lowest sequence of the Lesser Himalayan rocks is known as the Simla Slates (AUdEN, 1934) in Himachal, the Chakrata Formation (VALdIYA, 1980-a) in Kumaon and "serie de Kuncha" (BORDET, 1961) or the Kuncha Formation (STöCKLIN and BhatTaraI, 1977; Stöcklin, 1980) in Central Nepal. These formations consist of a monotonous, thick succession of alternation of phyllite, phyllitic gritstone and a lesser amount of quartzite. The Kuncha Formation and its westward continuation are distributed in the inner belt of Western and Central Nepal ("Chail" of FUCHS and Frank, 1970; ARITA et al., 1982), and the rocks in the Kali Gandaki river area were formerly named the "Simla Slate" by Fuchs and FranK (1970). In the Kali Gandaki area, they are more than $2 \mathrm{~km}$ thick, and are composed of slate and phyllite. These rocks are regarded as the lowest sequence of the Lesser Himalayan rocks in its lithological similarities to the Kuncha Formation, its great thickness incomparable to other formations and in having no carbonate rocks which have enough thickness to be compared with the carbonate formations in the overlying two groups. According to my reconnaissance surveys in the Kusma-Pokhara area and a geological map by ARITA et al., (1982, Fig. 8), these beds are underlain by monotonous alternating beds of quartzose sandstone and green phyllite which extend eastward to Kuncha. Therefore I regard these quartzite beds as a formation of the Lower Group although their stratigraphic relation to the Middle and Upper Groups is uncertain in the study area.

\section{Andhi Formation (2000 m+)}

The predominantly argillaceous Andhi Formation is distributed along the Kali Gandaki and Andhi Khola with a width of 3 to $6 \mathrm{~km}$. The best exposure can be observed in the area between Galyang and Grungdi along the lower stream of the Andhi Khola (khola means river in Nepali). It is separated by sharp, high-angle faults from the Middle and Upper Groups on both southern and northern sides respectively. Therefore, the stratigraphic top and bottom 


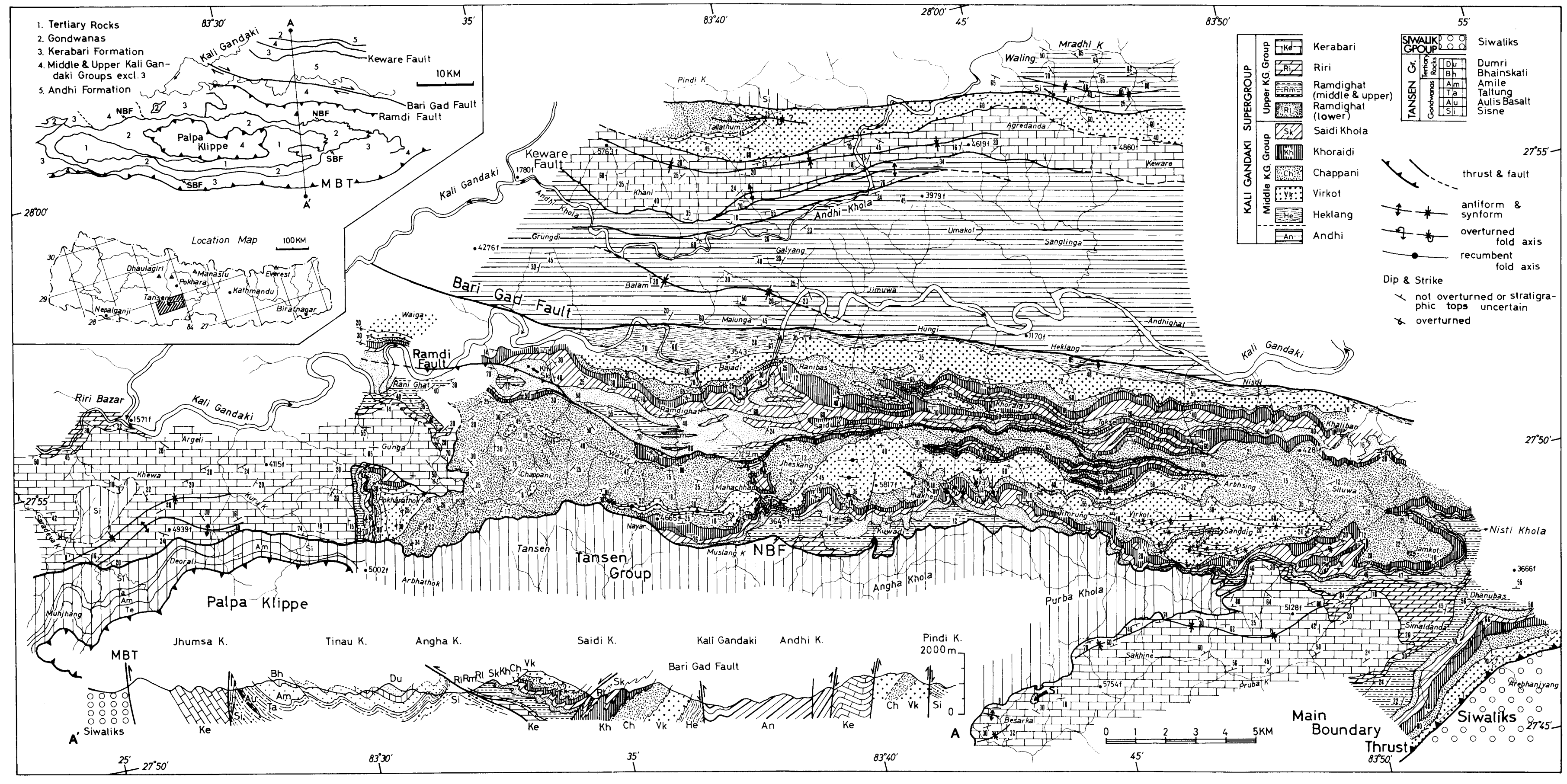

Fig. 4. Geological map of Kali Gandaki Supergroup around middle Kali Gandaki valley, north of Tansen. 
cannot be ascertained in the study area. This formation is a monotonous, thick sequence of phyllitic slate with occasional interbeds of thin, calcareous siltstone up to $10 \mathrm{~cm}$ thick. The slate is greenish-gray to brownish-gray and have a silver luster. A notable feature is frequent interlayering of black laminae or thin bands as in the form similar to the black laminae shown in Pl. 48-Fig. 4. Except these, no other sedimentary structures can be detected. This formation is so pervasively cleaved that recognition of bedding planes is difficult when no black laminae and sandy beds are present.

A dominantly argillite sequence similar to the Andhi Formation occurs in the Mradhi valley (northern end of the geological map, Fig. 4). It forms an open syncline and is separated from the Middle Group by high-angle faults on both northern and southern sides. It is tentatively regarded as the Andhi Formation. However, as it is also lithologically similar to the Heklang Formation, there is a possibility that the argillite in the Mradhi valley belongs to the Heklang. This problem will be solved by further investigation in areas to the east and west.

\section{Naudanda Quartzite}

Type locality: Along the Seti Khola at Naudanda

Thickness: 300 to $400 \mathrm{~m}$

Thick quartzite slabs form cliffs to the north of Naudanda along the Seti Khola and an inaccessible buttress to the WNW of Syangja (Fig. 5). This formation comprises a fine- to coarse-grained, white quartz arenite (orthoquartzite) with several interbeds of phyllite, conglomerate, and metabasite. The quartzites are strongly rippled and cross-bedded. They must have been deposited under a shallow marine environment, because the ripple marks are commonly of an oscillation type. They are more or less metamorphosed to metaquartzite containing muscovite. A study of thin sections under microscope of specimens

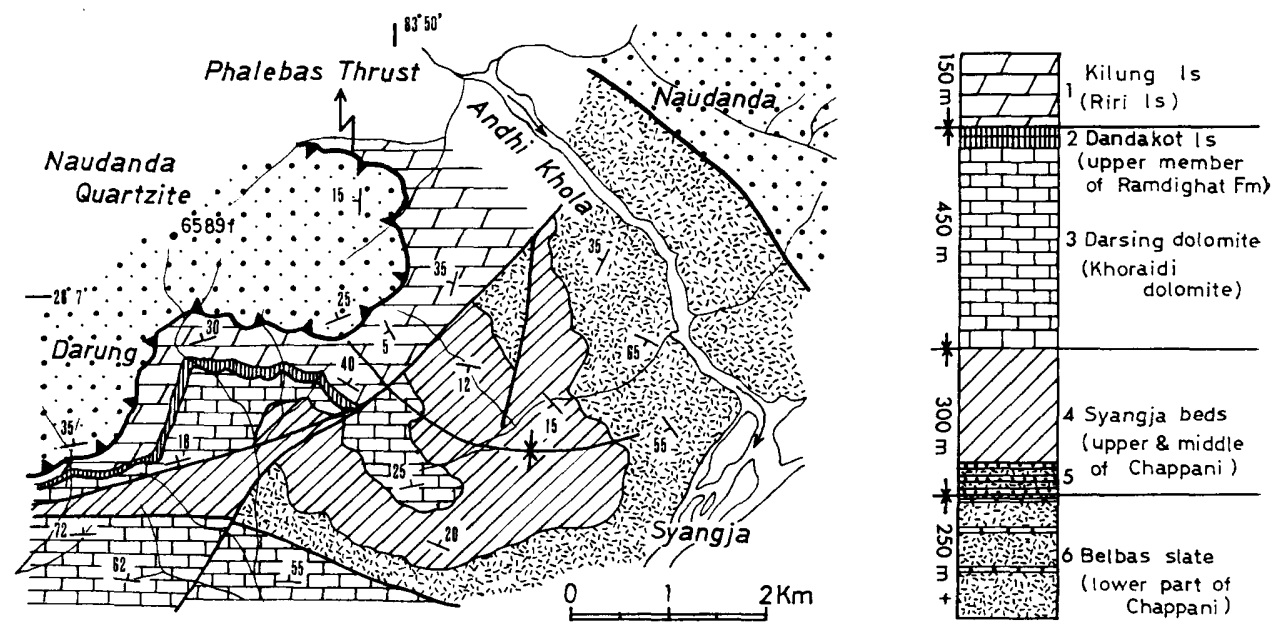

Fig. 5. Geological map of Kali Gandaki Supergroup around Syangja in inner belt of Lesser Himalayas. 
collected from a horizon at $30 \mathrm{~m}$ above the Phalebas thrust showed that the quartzites are completely recrystallized. The phyllites are bluish-gray to greenish-gray, and show a silky luster and a soapy weathering-surface due to the occurrence of chlorite and sericite. The Formation extends westward to the Kusma-Baglung area (Fig. 2), where many intercalations of metabasite are reported (UPRETI and MERH, 1979; UPRETI et al., 1980).

\section{The Middle Kali Gandaki Group}

The Middle Kali Gandaki Group is distributed in both the outer and inner belts. In the outer belt, this group crops out in three areas. The first is in the area between the Bari Gad Fault and the NBF of the Tansen Synclinorium. The group is structurally highly complex there. The second is in a narrow belt between the MBT and the SBF, where the group forms a homoclinal structure of a southern limb of the Tansen Synclinorium. The third is the Palpa Klippe that tectonically overlies the Tansen Group in the central part of the Tansen Synclinorium (see SAKAI, 1983, p. 68, fig. 23). In the inner belt, this group narrowly crops out between two subparallel normal faults in the northern part of the study area (Fig. 4), and in the Syangja area (Fig. 5). The rocks referable to as the same group is also extensively distributed in the area between Syangja and Waling. The Middle Group is subdivided into five formations as shown in Fig. 3. The group exhibits remarkably varied sedimentary facies as compared with the monotonous sequences of the Upper and Lower Groups, and is characterized by arenaceous and calcareous rocks that are considered to have been deposited under arid shoreline environments.

\section{Heklang Formation}

Type locality: Along the stream at $600 \mathrm{~m}$ south of Heklang village (Fig. 4)

Thickness: $800 \mathrm{~m}+$

The Heklang Formation is distributed in a narrow belt along the southern side of the Bari Gad Fault with a maximum width of $1.5 \mathrm{~km}$ (Fig. 4). No complete section is exposed. There occurs a small unmappable exposure just north of the MBT at the eastern corner of study area (Fig. 14 C-C'). The formation is gradational into the Virkot Formation. This passage can be observed in the type section, in which the basal part of the Virkot composed of alternating darkgreen and reddish-purple slates, each a few meters thick. I designate the upper limit of the Heklang at a horizon just below the lowest reddish-purple slate bed.

The Heklang Formation is composed mainly of dark-green phyllitic slate or phyllite. It commonly weathers brown and gray tints. The phyllite is intercalated at several horizons with up to 10-meters thick layers that frequently contain fine calcareous, laminae and bands. These layers are subordinately associated with calcareous sandstone, marl and dolomite in places. These carbonate rocks often weathers a coffee brown colour. 


\section{Virkot Formation}

Type locality: Upper reaches of the stream to the NW of Virkot village (Fig. 4)

Synonymy: The Bajadi Phyllite and Virkot Quartzite (SAKAI, 1983, 1984) are herein newly defined as Virkot Formation, as the much better section was obtained around Virkot village.

Thickness: $510 \mathrm{~m}$ along the type section (Fig. 6)

This Formation is repeatedly distributed by folding in the area between the Tansen Synclinorium and the Bari Gad Fault. It is also discontinuously exposed along the northern side of the MBT, where the formation shows a normal stratigraphic succession. There is another narrow belt of this formation in the
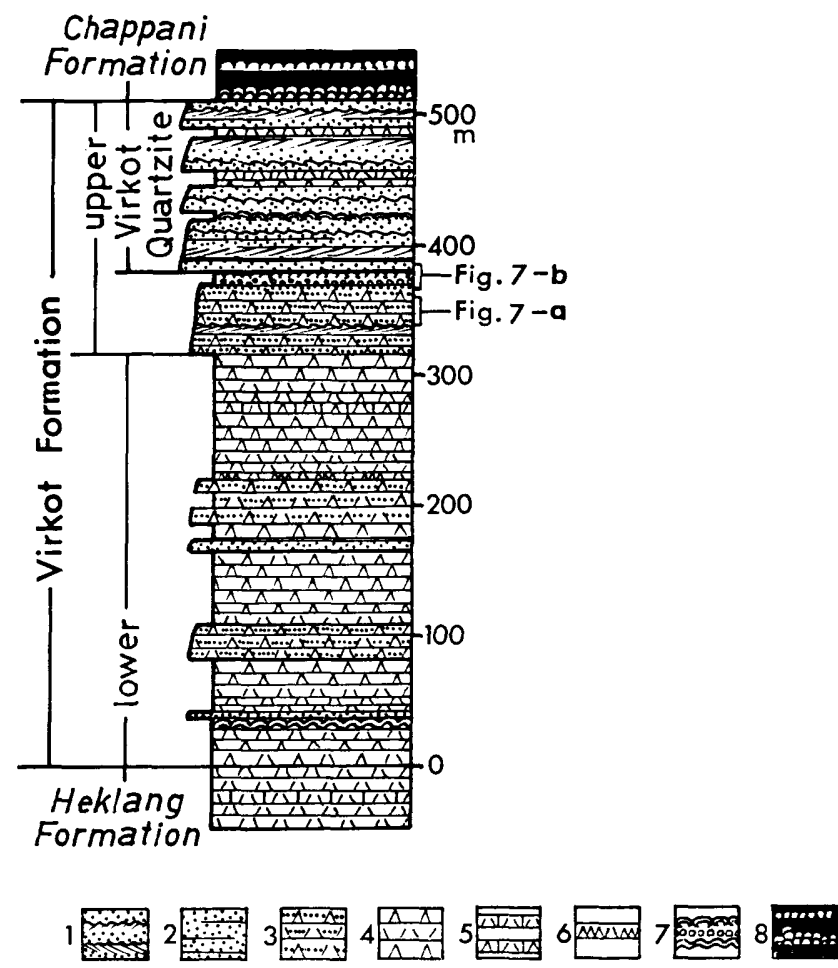

Fig. 6. Lithostratigraphic sequence of Virkot Formation and its stratigraphic relation to Heklang and Chappani Formations at type locality. 1, cross-bedded and rippled quartzose sandstone; 2 , massive and platy-bedded quartzose sandstones; 3 , alternating beds of quartzose sandstone and red-purple and green shale with sun-cracks and intraformational reworked pebbles; 4, red-purple and green shale; 5, calcareous red-purple and green shale; 6 , bioturbated misty shale; 7 , stromatolite with oolite; 8, columnar stromatolite of the Chappani Formation. 
northern part of the Kali Gandaki from Chitung to Keware, where it is bounded by normal faults on both northern and southern sides (Fig. 4).

This formation is composed of white to pink quartzite and reddish-purple phyllitic slate. Interlayering of these white and reddish-purple rocks gives a characteristic colour banding, which affords an important criterion to discriminate this formation from other argillaceous formations in the area of the complicated structures. White and reddish-purple colour banding is also found in the Middle Member of the Ramdighat Formation. However, these two formations can be distinguished from each other in that the white bands of the Virkot are represented by quartzite beds, whereas that of the Ramdighat by limestone, dolomite and calcareous slate.

The base of this formation is placed at the first bed of red shale as mentioned before. The lower part of the formation is predominantly reddish-purple phyllitic slate, and the upper part comprises predominantly quartzose sandstone that is named the Virkot Quartzite Member (SAKAI, 1984; Fig. 6). This formation exhibits an upward-coarsening and -thickenning sequence as a whole.

\section{a. Lower Member}

The Lower Member, $300 \mathrm{~m}$ thick, is characterized by monotonous reddishpurple shale that has been more or less converted into phyllite with closely spaced crenulation cleavages. Fine, calcareous laminae are rarely recognized on the fresh and wet outcrops.

The shale beds at several stratigraphic levels are intensely bioturbated and exhibit a finely mottled lithology and variegated colour. Irregular-shaped, green shale layers, which are mostly thin, but sometimes up to $10 \mathrm{~m}$ thick, are commonly contained. The banded shale and quartzite beds, which repeat in 1 to $10 \mathrm{~m}$ thickness, are intercalated at two stratigraphic levels in the type area (Fig. 6). Sun cracks and reworked shale- and dolomite-pebbles layers are occasionally observed in the red shale and in the quartzite beds, respectively. The lithofacies of these banded rocks resembles that of the lower part of the Virkot Quartzite. A 2-meters thick algal dolomite occurs in the lower part of this member (Fig. 6). This bed shows weakly and regularly undulated algal laminae. It directly rests on light-green shale and is overlain by rhythmically alternating beds of quartzose sandstone and reddish-purple shale. This is the lowest stromatolite horizon in the Kali Gandaki Supergroup of the Tansen area.

\section{b. Upper Member (Virkot Quartzite)}

This member is a 200-m thick, distinctive unit predominantly composed of white to pink quartzite and occasionally forms inaccessible cliff. The member is subdivided into two parts.

The lower part is an alternating sequence of quartzite and interbedded pink, white and light-green quartzite and red or green shale. Each unit is a few to $5 \mathrm{~m}$ thick. The regular colour-banding affords an important criterion to distinguish this unit from other units of similar lithologies in the complicated area. A typical sequence at the river bank between Virkot and Heklang is shown in Fig. 7-a. Along this section both units repeat twice within 
the thickness of $7 \mathrm{~m}$. The quartzite unit shows a $10-$ to $20-\mathrm{cm}$ thick wavy and plannar bedding occasionally with thin red or green partings. These partings usually have a soapy luster due to fine sericite. The grain-size of the quartzite averages 0.2 to $0.3 \mathrm{~mm}$, but their grain-size frequency commonly exhibits bimodal distribution; one is well-rounded quartz grains with diameter of 0.5 to $0.8 \mathrm{~mm}$ and the other is subangular to rounded ones of 0.05 to $0.3 \mathrm{~mm}$ diameter. Well-rounded, medium to coarse micrite grains are occasionally contained. Fine-grained granophyre fragments and well-rounded tourmaline grains are rarely recognized. The sorting and the amount of a matrix are varied, and almost all of the quartzite belong to quartzose arenite. Cross-bedding and ripple marks are common, and herringbone cross-bedding is rarely observed (Fig. 7-a). The palaeocurrent direction obtained from these sedimentary structures is from SE to NW or NW to SE. All of these petrographic features of the quartzite unit are quite similar to those of the Upper Quartzite Member of the Chappani Formation.

The interbedded quartzite and shale unit rhythmically alternated with each other in a few to $5 \mathrm{~cm}$ thickness. The quartzite shows plannar and wedgeshaped bedforms with parallel- and cross-laminae of reddish-purple and lightgreen colours. Varicoloured shale flasers are commonly contained. Ripple-cross lamination and asymmetric ripple marks are rarely found. The petrographic features of the quartzite resemble those of the quartzite unit mentioned above. There are some interlayers of lenticular or irregular-shaped, low-matured quartzose wacke (Fig. 7-a). The shale occurs as various forms; thin parting, 1 to $5 \mathrm{~cm}$ thick, mud cracks and intraformational flat-pebble conglomerates. The petrographic characters are consistent in spite of the differences of bedforms. Polygonal mud cracks are commonly found and are the most distinctive sedimentary feature of the Virkot Formation (Pl. 42-Fig. 1 and 2). The desication cracks are 0.5 to $5 \mathrm{~cm}$ wide, and are usually filled with quartzose sandstone. These mud crack layers have frequently resulted in shale-pebble conglomerates formed by penecontemporaneous erosion and resedimentation, and are also incorporated into the overlying quartzite beds as angular-shaped shale-pebbles (Pl. 42-Fig. 1, and Fig. 7-a).

The top bed of the lower part of the Virkot Quartzite Member is well defined by a set of a $25-\mathrm{cm}$ thick oolitic limestone and a-15 $\mathrm{cm}$ thick stromatolite (Figs. 6 and $7 \mathrm{~b}$ ), which can be traced in an extensive area around Tansen. This bedset is useful in many aspects: firstly, it serves for definitely distinguishing the Virkot Formation from the Upper Member of the Chappani Formation which has lithologies similar to the Upper Member of the Virkot; secondly it indicates a distinctive stratigraphic level within the Upper Member of the Virkot Formation which repeats similar lithologies many times; thirdly the convex shape of the stromatolite determines the stratigraphic top in the complexly folded area where overturned limbs of recumbent folds repeat many times; fourthly the rapid change from this bedset to the overlying pale-pink, thick-bedded quartzite makes it easy to recognize this horizon.

The oolitic limestone is composed of ooids ranging from 0.5 to $1 \mathrm{~mm}$ in diameter, peloids smaller than $0.5 \mathrm{~mm}$ in length, and a minor amount of detrital 
quartz grains. The matrix is micrite. The ooids show a concentric structure surrounding detrital quartz nuclei. It is worthy to note that most of the ooids is radially cracked, and some are broken to triangular-shaped fragments. The stromatolitic limestone forms columnar- and dome-shapes 3 to $8 \mathrm{~cm}$ across and 10 to $15 \mathrm{~cm}$ high. The columns are laterally close-linked without any space, and consist of alternating dark and light laminae 0.5 to $1 \mathrm{~mm}$ thick. Very fine laminae as thick as $0.01 \mathrm{~mm}$ can be recognized within the dark laminae. There are no marked organic laminae as in the stromatolites of the Khoraidi Formation. Just above the stromatolite bed there is a $1 \mathrm{~m}$ thick laminated gray shale and quartzite bed, which contains closely packed, hemispherical to ellipsoidal sandstone spherules of 0.5 to $2 \mathrm{~cm}$ diameter. Some of these spherules cut the laminae of shale and exhibit a half-moon shape. Their origin may probably be attributed to rain prints. The same type of spherules are also detected at a horizon in the Upper Member of the Virkot Formation.

The lithologic combination of the upper part (Virkot Quartzite) of the Upper Member is similar to that of the lower part, but quartzite beds are over-

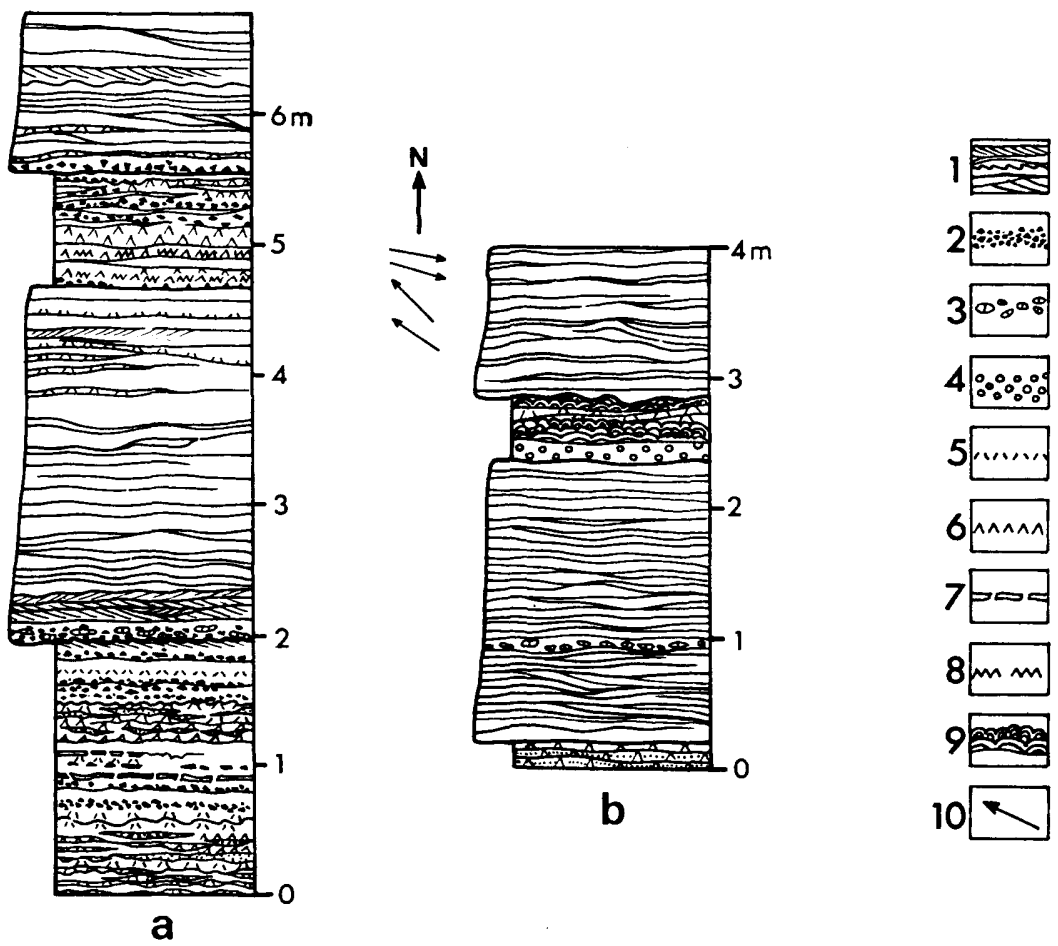

Fig. 7. Detailed columnar section showing characteristic sedimentary structures of lower half of Upper Member of Virkot Formation. 1, ripple, cross-bedded quartzite; 2 , reworked shale-pebbles; 3 , reworked dolomicrite-pebbles; 4, oolitic limestone with detrital quartz grains; 5 , green shale with a silver luster; 6 , red-purple shale with a luster; 7 , mud crack; 8, bioturbation; 9, stromatolitic limestone; 10, palaeocurrent direction. As for the stratigraphic position of sections, refer to Fig. 6. 
whelming and much thick-bedded up to a few tens meters. They are coloured pink and exhibit plannar and wedge-shaped bedforms with remarkable ripples and cross-lamination. The lithologic and petrographic characters of the quartzite are not so different from those of the lower part of the Upper Member and the Lower Member. The major palaeocurrent directions obtained from the ripple marks and cross-bedding indicate the same trend from SE to NW and NW to $\mathrm{SE}$ as in the lower part. In the Angha Khola and Virkot areas a dolomitic stromatolite bed occurs at $40 \mathrm{~m}$ above the base of the upper part. It directly rests on the blood-red coloured quartzite, and its maximum thickness reaches $80 \mathrm{~cm}$. The stromatolites are domed to bulbous-shaped and range from $10 \mathrm{~cm}$ to more than $50 \mathrm{~cm}$ in diameter. This bed is unique in that lenticular quartzose sandstone bands up to $2 \mathrm{~cm}$ thick are commonly interbedded with stromatolite laminae. These bands are composed of sub-rounded to well-rounded, fine sands and a dolomitic matrix. Fine shrinkage cracks are sometimes found in the stromatolite laminae.

\section{c. Sedimentary Facies}

The occurrence of desiccation cracks in the interbedded quartzite and reddish-purple shale unit of the Upper Member clearly indicates that this unit was deposited under arid conditions. The reddish-purple shale beds in which mud cracks are present are considered to have accumulated in ephemeral flood water lakes or plains, and the mud cracks have been formed by desiccation during the dry period. The curled mud flakes have been eroded by flash floods caused by sporadic rainfall, and redeposited as intraformational shale-pebbles in nearby areas. Sandy and muddy hemispheric particles mentioned above were probably made by the rain drops fallen on the dry sand or mud surface.

The quartzite unit of the lower part of the Upper Member is interpreted to have formed as a sand dune. Their wavy and plannar bedforms with crossbedding, herringbone cross-bedding and ripple marks indicate the mixed origin of eolian and water current including tide current near the shoreline. The petrographic features, especially bimodal grain-size frequency distribution, and interbedding of well-sorted fine-grained sands and fine- and coarse-grained mixed sands are attributed to the products of deflation-lag sedimentary process by wind action. The existence of well-rounded and spherical quartz grains suggests a long abrasion history including wind-blown processes. The stromatolites at three horizons within the quartzite beds support that the quartzite beds were deposited near the intertidal zone. The underlying oolitic limestone also reflects almost the same depositional environment and the cracked ooids imply their rapid shrinkage by desiccation after deposition.

On the other hand, the reddish-purple and green shale beds which are predominant in the Lower Member suggest their deposition mainly by suspension in a lagoonal environment. The accompanied quartzite interbeds probably represent sand bar or lagoonal beach deposits on the rear side of the lagoon. The intensely bioturbated and variegated misty mudstone intercalated between the quartzite unit below and the reddish-purple or green shale unit above (Fig. 7) is interpreted as a transitional intertidal facies from subaerial dune to lagoon. 
The Virkot Formation is as a whole regarded as a progradational sequence under arid conditions from a lagoon to a shoreline sand dune with ephemeral river systems on the flood plain on the rear side (Fig. 13). The vast continent with exposures of weathered granite and gneiss was underlain as a source area, because the quartzite of the Virkot is matured and contains wellrounded plutonic quartz grains and a minor amount of microcline, perthite, tourmaline, and granophyre grains.

\section{Chappani Formation}

Type locality: Upper stream of the Nisti Khola, $1.5 \mathrm{~km}$ south of Dhanubas (Fig. 4)

Thickness: $400 \mathrm{~m}$

The Chappani Formation is distributed in two to four belts, having been repeated by folding, in the area between the Bari Gad Fault and the Tansen Synclinorium. It is most widely exposed around Siluwa village in the upper valley of the Nisti Khola and around Chappani $2.5 \mathrm{~km}$ north of Tansen, where the bedding planes conform with the topographic surface of valleys. In the northern flank of the Kali Gandaki, the formation crops out around Tallatum village, where it is bounded by high-angle normal faults on both northern and southern sides. In these areas thickness remarkably varies in places due to the structural repetition of beds by folding and truncation of beds by thrust faults. A complete section in exposed along the upper reaches of the Nisti Khola, 1.5 $\mathrm{km}$ south of Dhanubas, where the continuous, normally dipping sequence from

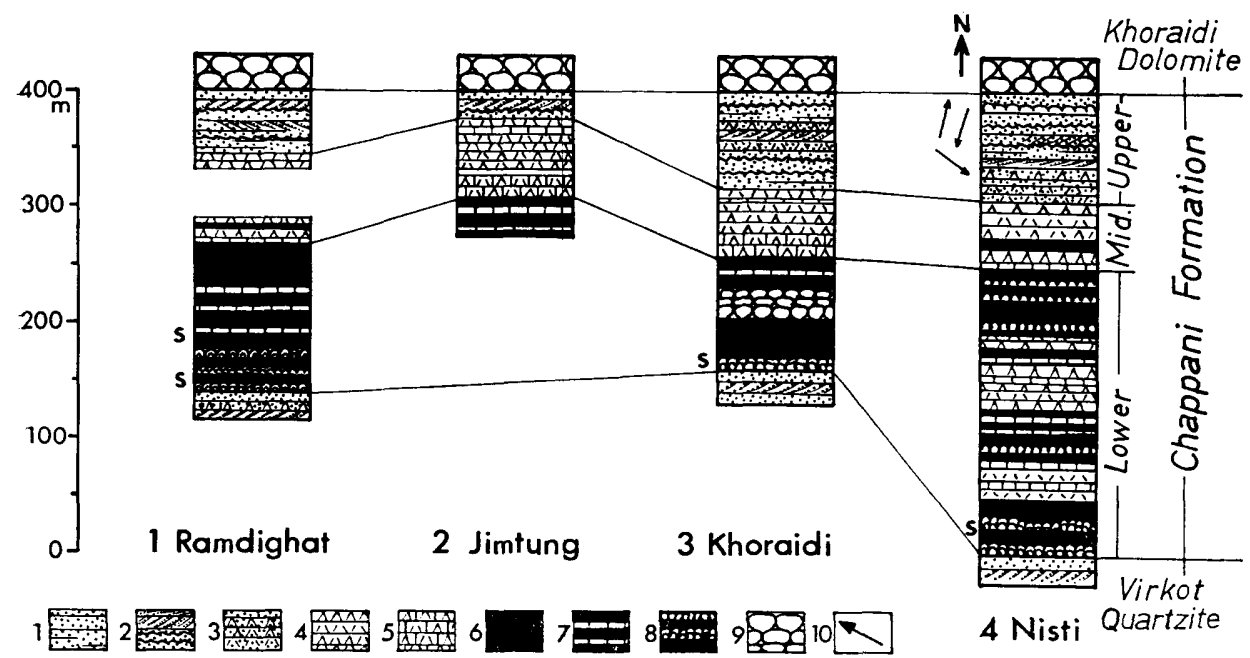

Fig. 8. Comparative lithostratigraphic section of Chappani Formation. 1, platy bedded to massive quartzose sandstone; 2 , cross-bedded and rippled quartzose sandstone; 3, alternating beds of quartzose sandstone and red-purple and green shale; 4, red-purple and green shale; 5 , calcareous red-purple and green shale with thin interbeds of limestone; 6 , calcareous black clayslate; 7 , creamy-white muddy limestone; 8, columnar stromatolite and algal limestone; 9 , large-sized stromatolite; 10 , palaeocurrent direction; $\mathrm{s}$ : silicified stromatolite. 
the Virkot to the Ramdighat Formation can be observed. Therefore I designate this section as the type section of the Middle Group. The name of this formation is, however, taken from Chappani village mentioned above, because the formation is the most widely exposed there.

The Chappani Formation conformably rests on the Virkot Quartzite (Fig. 8). The basal bed of the formation is characterized by a silicified stromatolite bed that shows protruded topographic feature on outcrops due to the differential weathering of the hard silicified stromatolite and the overlying fissile slate.

The formation is divided into three members; the Lower Member is composed mainly of gray slate and stromatolitic limestone, the Middle of thinly laminated light-purple and green clayslate, and the Upper of quartzite. The lithology of the Upper Member is similar to that of the Virkot Quartzite. Thus identification of this member is difficult in structurally complex areas. However, these two units can be discriminated in the following points; the Virkot Quartzite is dominantly coloured pink, whereas the Chappani quartzite white, light-green and pale-orange. The Chappani has no oolite bed. It is also difficult to distinguish the laminated clayslate of the Lower and Middle Chappani from the Heklang and Andhi phyllite and from the slate of the Riri Limestone Member on weathered outcrops. The Chappani clayslate is accompanied by calcareous, small-sized stromatolites at several stratigraphic levels. The most distinctive criterion is their stratigraphic relations to the over- and underlying units.

\section{a. Lower Member}

The basal silicified columnar stromatolite bed one to a few meters thick directly rests on the Virkot Quartzite with a sharp boundary (Fig. 8). It is followed by a thick sequence of gray slate which characterizes the Lower Member. The slate usually weathers creamy white due to leaching of calcareous components. The slate is intercalated with pale-greenish, fine parallel-laminated clayslate in several sections, and with white to light-gray, calcareous stromatolite beds in every section (Fig. 8). The distinction of these rocks are, however, often difficult, because these rocks assume the same colour and appearance when they are intensely weathered.

In addition, these rocks have been suffered from low-grade metamorphism, and the bedding planes are obscured by the crystallization of fibrous white mica along slaty cleavages which are arranged diagonal to bedding planes. The slate is composed of calcareous clay, and a small amount of detrital quartz and white mica smaller than $0.05 \mathrm{~mm}$. There are two types of quartz grains; one is angular and the other is well-rounded. Small pyrite crystals sporadically occur in gray to black slate, and can be observed even under naked eyes.

Micritic limestone and stromatolite beds occur at several stratigraphic levels. Those of the type section are shown in Fig. 9. Stromatolite beds are 0.1 to $1 \mathrm{~m}$ thick, and micritic limestone occurs as thin beds and lenses. The stromatolites of this member show a wide morphological variation, but the most characteristic is of the columnar and branched form (Fig. 9, Pl. 43-Fig. 4). It shows closely spaced, subcylindrical columns of 5 to $15 \mathrm{~cm}$ diameter in the longitudinal section. Each column is subelliptical to subcircular in the trans- 
verse section. The columns usually possess a uniform diameter at the basal part, but increase in diameter and decrease in curvature of algal laminae upward. Branching occurs a little after widening of the parent column. Intercolumnar spaces vary from 0.5 to $5 \mathrm{~cm}$ and are filled with micritic limestone. The alternating dark and light laminae are 0.1 to $1 \mathrm{~mm}$ thick, and the former consists of very fine micrite and the latter of sparry calcite which contains some detrital quartz grains and mica flakes of 0.01 to $0.05 \mathrm{~mm}$ size. These dark and light lamina-sets are commonly bounded by a thin organic layer. The morphological and textural features of stromatolite of this type indicate that they probably belong to Kussiella which has been reported from the Trisuli valley in Central Nepal by VALDIYA (1980-c). Another type of the stromatolites is laterally-linked, closely spaced columns which grew nearly vertically. They range in diameter from 10 to $20 \mathrm{~cm}$ and reach $1 \mathrm{~m}$ in the maximum height. The basal silicified stromatolite belongs to this type, and resembles Jurusaria which is known from the Trisuli valley (VALDIYA, 1980-c). Planar or slightly undulating stromatolite with faint algal laminae is commonly recognized. Micritic limestone is structureless but it may be of algal origin (Fig. 9).

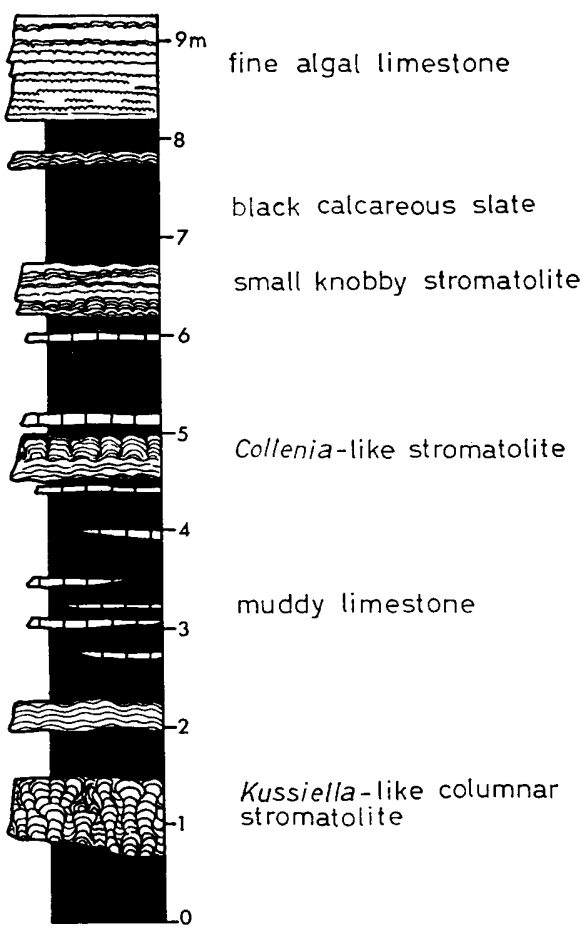

Fig. 9. Detailed columnar section of part of Lower Member of Chappani Formation, showing occurrence of stromatolite and algal limestone beds at northwest of Arebhanjyang (southeastern corner of Fig. 4). Note lack of coarse-grained detrital beds. 


\section{b. Middle Member}

The Middle Member is a 50- to $70-\mathrm{m}$ thick sequence characterized by rhythmically laminated red-purple and green, calcareous clayslate. Its lithofacies, microtexture and component are very similar to the laminated red-purple and green clayslate of the Lower Member, but the shade of a colour grades up-section from faint pale-green or pink to light-green or purple. 5 to $10 \mathrm{~cm}$ thick, creamcoloured micritic limestone beds are occasionally intercalated.

\section{c. Upper Member}

The Upper Member is characterized by white, greenish and pinkish, thick, massive quartzose sandstone, and begins with a $10-\mathrm{m}$ thick quartzose sandstone. In the type section (Fig. 8-4), the basal sandstone is intercalated with rhythmically alternating beds of 3 to $10 \mathrm{~cm}$ thick, fine sandstone and light-green shale in the lower part. The sandstone appears to be as thick as more than several meters, but the interlayering of thin shaly interlayers, ripplemarks and parting lineations indicate that they have resulted from the amalgamation of beds 5 to $30 \mathrm{~cm}$ thick. In the sandstone, ripplemarks, ripple-cross lamination and wedge-bedding are common, and many, purple and green reworked flat-pebble beds are interstratified. These sedimentary structures indicate the consistent palaeocurrent directions from $\mathrm{E}$ to $\mathrm{W}$ and $\mathrm{SW}$ to $\mathrm{NE}$. The thickness of the member varies from a few tens of meters to $100 \mathrm{~m}$ in places, but the lithofacies and petrographic features are consistent throughout the area studied. One of the important lithologic features is the occurrence of eolian sandstone beds and disseminated sand in dolomite beds. The former occurs as the following two types: The first type is pink orthoquartzite that exhibits 20 to $30 \mathrm{~cm}$ thick, trough and planar cross-beddings. It is composed of well-rounded and wellsorted, fine- to medium-grained quartz and a minor amount of red and vermilion jasper. The matrix consists of micro crystalline quartz and white mica. The quartzite of this type is interpreted to have formed as coastal sand dunes. The second is pink or light-pink to white quartzite which ranges in thickness from 1 to $10 \mathrm{~cm}$, and consists of an anomalous mixture of large and small grains. The large grains are composed of well-rounded, granule-sized to coarse quartz, whereas the small ones of angular to rounded, well-sorted, very fine sand and silt. Thus the size-frequency distribution shows a remarkable bimodal pattern. These quartzite bands occasionally form large-scale cross-bedding. These features are considered to represent the deflation-lag sediments deposited by strong wind action in an eolian environment. The sand grains disseminated in dolomicrite beds and bands, which are not uncommonly intercalated in the quartzite beds, are mostly quartz and are fairly well-rounded and well-sorted. They are scattered in the dolomicrite as if having been floated without forming laminae or bedding (Pl. 49, Fig. 4). These sand grains are interpreted to have settled as wind-blown sands on the lime mud. The dolomicrite in which the above-mentioned sand grains are contained are light-gray, rosy-pink and creamy white. 


\section{d. Sedimentary Facies}

The clayslate of the Lower and Middle Members represents the deposits of fine suspended material in a calm water environment. The micritic laminae in the clayslate indicate constant settling of limy mud. On the contrary finegrained, graded sandy laminae probably indiacte the influx of terrigenous material by turbid current caused by sporadic rainfall under arid conditions. The silver-gray, fine laminae which are composed of metamorphic white mica imply that these laminae were primarily aluminous clay which was supplied from almost completely weathered residual soil. The black clayslate and authigenic pyrite suggest reducing and stagnant water conditions. The stromatolites of the Lower Member are small and slightly undulating, and suggest their growth in a supratidal pond or marsh to a logoonal environment. To sum up, the depositional environment of the Lower Member is probably a lagoon, which was located along the continental margin, under arid climates. The basal silicified columnar stromatolites are considered to have formed in the intertidal zone and to represent a transitional environment from the underlying shoreline-dune complex of the Virkot Quartzite and the overlying subtidal lagoonal clayslate. The upper Member is interpreted as a lagoonal beach and eolian dune complex bordered by algal marsh on the landside and facing to lagoon on the seaside.

The Lower and Middle Members of the Chappani Formation represent a transgressive or subsiding basin sequence. This sequence succeeded by the flood plain and beach dune deposits of the Upper Member. This change indicates a regressive or upheaval movement of the Chappani depositional basin.

\section{Khoraidi Formation}

Type locality: Middle stream of the Khani Khola, west of Khoraidi (Fig. 4)

Thickness : $350 \mathrm{~m}$

\section{a. Stratigraphy}

The Khoraidi Formation is made up of more than 80 percent dolomitic stromatolites and the remaining other kinds of rocks comprising oolite, oolitic quartzose sandstone, quartzite, rhythmite of thin sandstone and intraformational

\section{Explanation of Plate 42}

Fig. 1: Polygonal muderack moulds in quartzose sandstone of the Virkot Formation along the Angha Khola.

2: Cross-bedded quartzose sandstones with sun-cracked red-purple shale layers of the Virkot Formation in the Palpa Klippe. Mudcracks at some levels are eroded and reworked to form an intraformational shalepebble conglomerate.

3: Overturned, rippled quartzite bed of the Upper Member of the Chappani Formation to the east of Ramdighat. This bed is overlain by tabular cross-stratified quartzose sandstone.

4: Gypsum pseudomorphs in quartzose sandstone of the Khoraidi Formation along the Saidi Khola. The stratigraphic position at which the pseudomorphs occur is indicated in Fig. 10 . A scale bar is $20 \mathrm{~cm}$. 

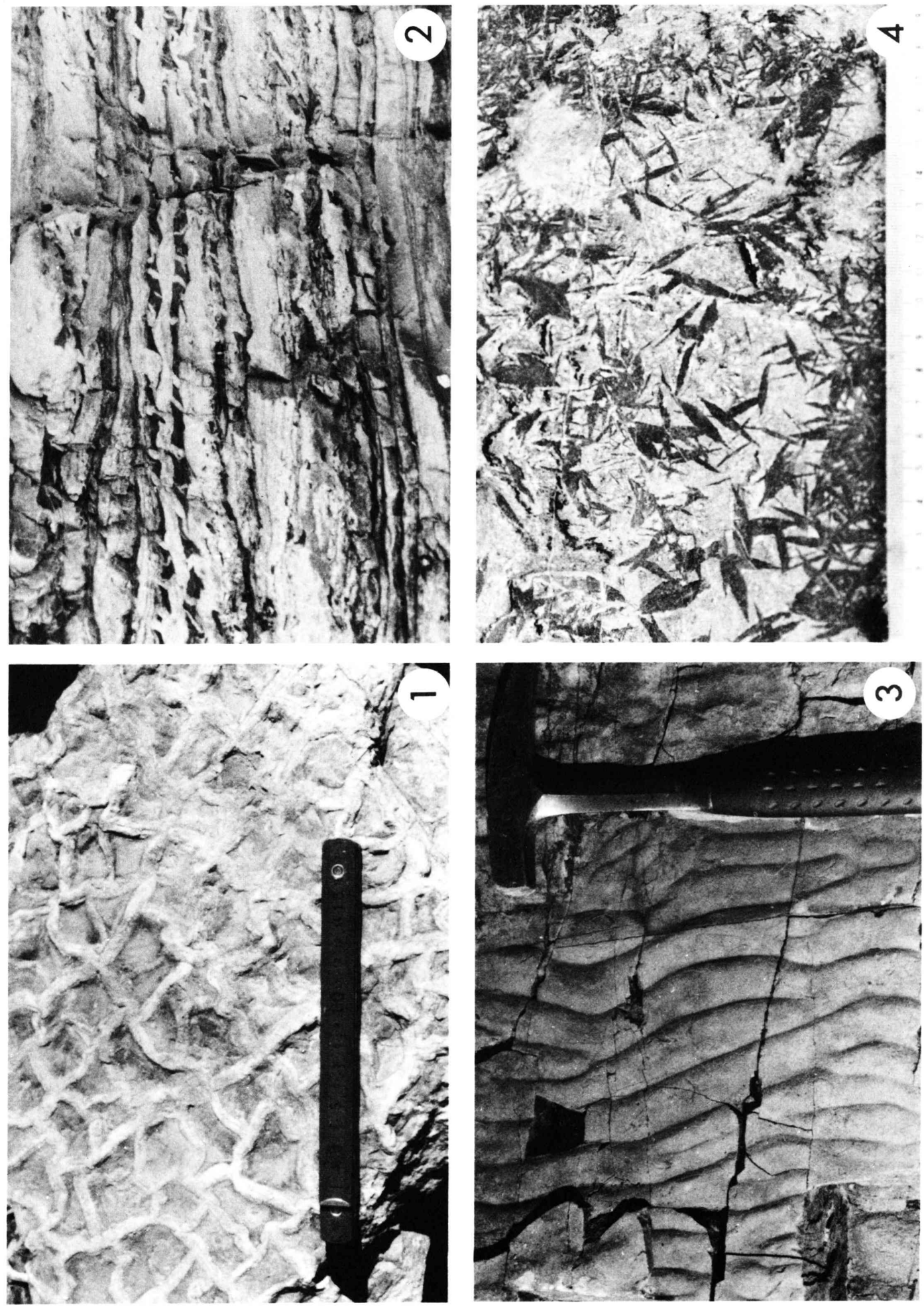

H. SAKaI: Kali Gandaki Supergroup 

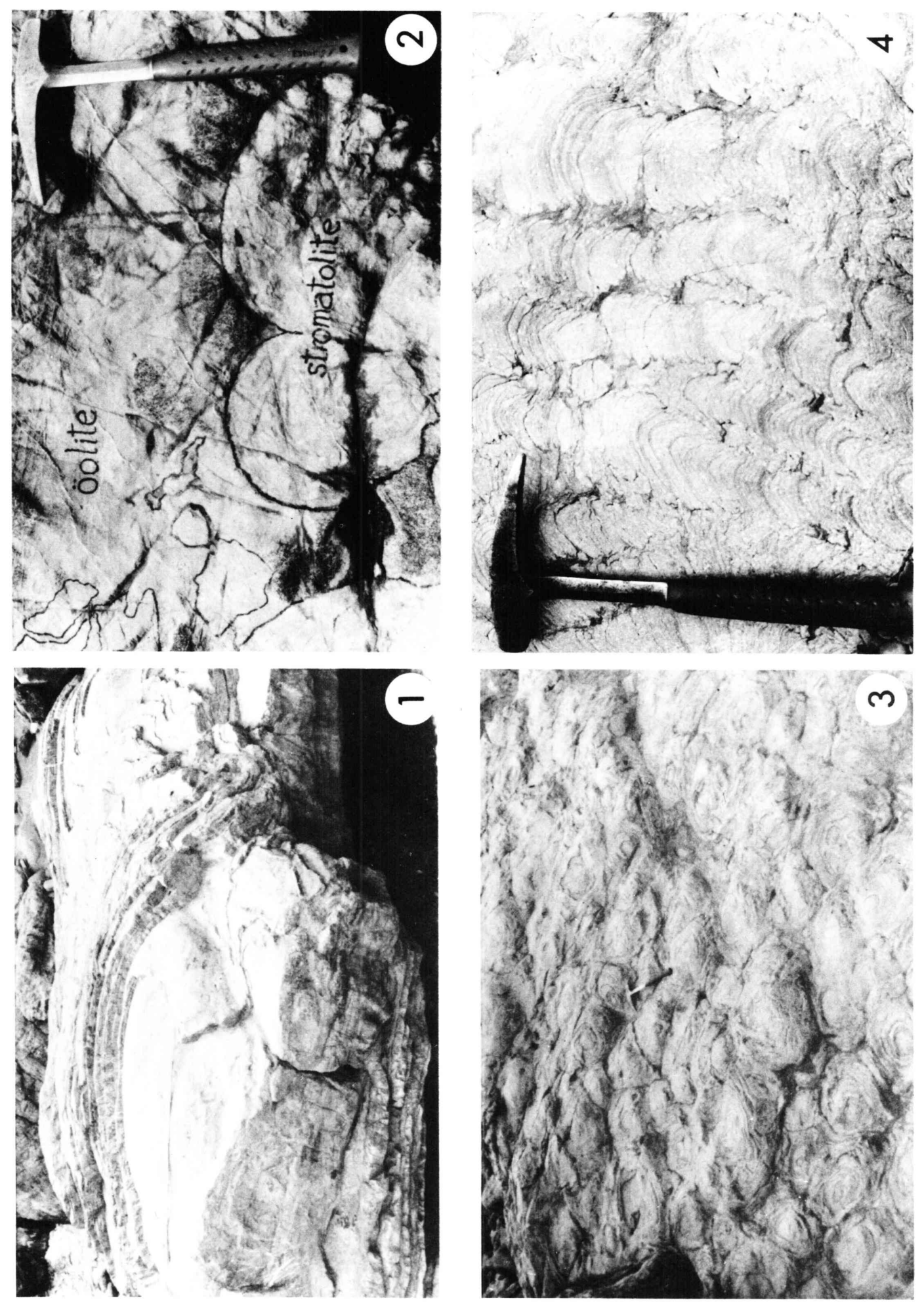

H. SAKaI: Kali Gandaki Supergroup 
reworked pebble conglomerate. The thick sequence of large-sized stromatolites plays an important role not only as a useful key bed but also as a criterion for the top and bottom determination of strata in complexly folded areas. The formation crops out in three to seven belts owing to the repetition by folding in the area between the Bari Gad Fault and the NBF of the Tansen Synclinorium (Fig. 4). The thickness of the formation varies from $350 \mathrm{~m}$ to a few tens of meters in places due to structural modifications by faults and folds.

The base of the Khoraidi Formation is placed at the first appearance of large stromatolites which directly rest on the thick quartzite beds of the Chappani Formation (Fig. 8-3). This formation consists of alternating beds of stromatolite and predominantly quartzose sandstone of various thickness, as seen in Fig. 10. The thickness and the frequency of occurrence of these stromatolite beds vary in places, but no marked lithological changes are recognized throughout the sequence. Therefore it is difficult to define the stratigraphic horizons within the formation.

\section{b. Lithology \\ Stromatolites}

Although the Khoraidi Stromatolites are fairly varied in shapes and sizes from bed to bed but no definite changes of morphotypes can be observed throughout the sequence. Especially within a bed, their sizes and shapes are almost invariable. Morphologically they are divided into the following five morphotypes :

a. flat to undulatory laminated, sheet form

b. tabular form

c. columnar and conical form

d. subspherical to dome form

e. oncolite

The former four types form biostromes and the last one is associated with oolite beds. In their occurrence the most common is the biostromes in which subspherical- to dome-shaped stromatolites occur in the lower part and is succeeded by tabular-shaped ones (Fig. 10). The biostromes which consist largely of the tabular form stromatolites are also common. The columnar and conical

\section{Explanation of Plate 43}

Fig. 1: Large flattened dome-shaped stromatolite which attains $2 \mathrm{~m}$ in diameter. Khoraidi Formation to the south of Virkot. A scale bar is $1 \mathrm{~m}$.

2: Subspherical or high dome-shaped stromatolite and overlying oolite bed of the Khoraidi Formation at Gokunga, $10 \mathrm{~km}$ southwest of Riri Bazar. Intercolumnar space of stromatolites is filled with small ooids.

3: A plan view of subspherical stromatolite biostrome along the Angha Khola. No intercolumnar spaces between stromatolites. Khaoraidi Formation.

4: Columnar and branched, Collenia-type stromatolite of the Chappani Formation to the north of Arebhanjyang. 
stromatolites occasionally occur associated with the subspherical to domeshaped ones (Fig. 10), but are not so common as in the Chappani Formation. An important fact is that no Collenia- and Kussiella-type stromatolites occur in the Khoraidi. The sheet-formed stromatolites are not common as well. This type occurs more commonly in the inner belt around Syangja, where silicified cherty layers are sometimes intercalated.

The diameter of the subspherical (Pl. 43-Fig. 3) and domed forms ranges from $10 \mathrm{~cm}$ to $1 \mathrm{~m}$, and that of the tabular one (Pl. 43-Fig. 1) is up to $4 \mathrm{~m}$. Their heights range from $10 \mathrm{~cm}$ to $70 \mathrm{~cm}$. They often thickly grew without intercolumnar spaces (Pl. 43-Fig. 3), and are laterally linked to form an extensive biostrome 0.5 to $1.5 \mathrm{~m}$ thick. The interspaces, if present, are usually filled with reworked stromatolite flakes, dolomite breccias and ooids.

Laminar structures are well preserved in the stromatolites of the Khoraidi Formation, and exhibit banded microstructures of alternating black organic

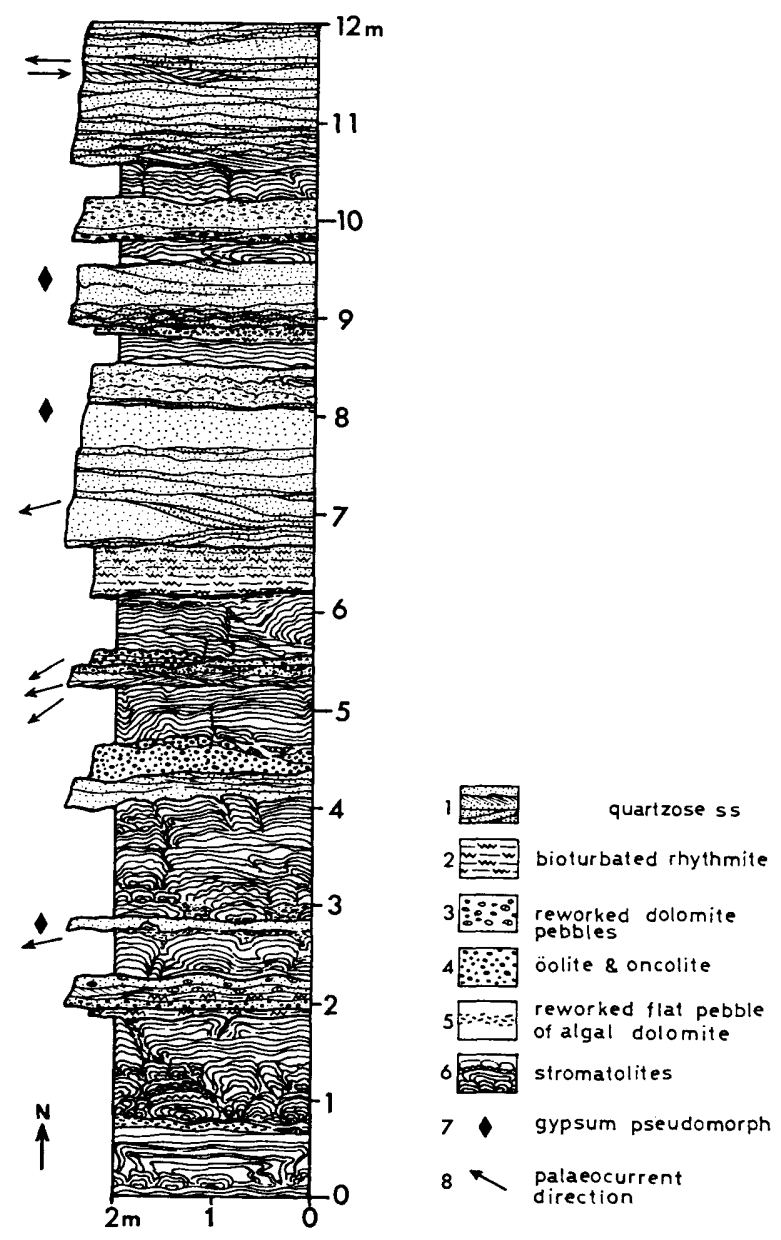

Fig. 10. Detailed columnar section of part of Khoraidi Formation at south of Dhanubas, southeastern corner of Fig. 4. 
laminae and dolomicritic laminae. Distinct black laminae 1 to $2 \mathrm{~mm}$ thick are rhythmically stacked at $1-$ to $2-\mathrm{cm}$ intervals in which crinkled cryptolaminae occur at a few-mm interval. The dolomicritic layers contain a fairly large amount of quartz grains 0.05 to $0.1 \mathrm{~mm}$ diameter and muscovite flakes $0.1 \mathrm{~mm}$ long. Microscopically these microstructures are obliquely cut by cleavages. In the stromatolites of the Darsing Dolomite (Fig. 5) in the inner belt, these microstructures are much poorly preserved because of recrystallization.

Oncolite beds mostly occur along with calcareous sandstone and oolite which are interbedded with the above-mentioned stromatolite biostromes. The contained oncolites are small-sized, 1 to $5 \mathrm{~mm}$ diameter (Pl. 49-Fig. 2), and the interparticle spaces are filled by coarsely crystalline mosaic dolomite. Composite oncolites are commonly present. Encrusting lamellae consist usually of 5 to 10 alternating dark and light layers, but as the oncolites are often replaced by microcrystalline quartz, their detailed structure cannot be known.

\section{Oolite}

Oolite beds occur at many horizons in the Khoraidi Formation, and mostly are associated with quartzose sandstone beds. They are usually from $5 \mathrm{~cm}$ to $70 \mathrm{~cm}$, rarely up to $1 \mathrm{~m}$ thick. Most of them show wedge- or lenticular-shaped bedforms and irregular bedding surfaces. No marked local variation of occurrence is recognized throughout the whole study area.

Oolite of this formation can be classified into two types: oodolosparite and arenaceous oodolosparite. Oodolosparite is composed of spherical to subspherical ooids of a uniform size 1.0 to $1.2 \mathrm{~mm}$ diameter. The interparticle pores are usually filled by sparry dolomite. A small amount of peloids 0.1 to $0.2 \mathrm{~mm}$ diameter are sometimes contained. Ooid nuclei are mostly detrital quartz grains, which sometimes display an idiomorphic crystal formed by overgrowth. Oolite is more or less recrystallized, but in a well-preserved sample (Pl. 49-Fig. 1), the ooids show fine concentric lamellae and very fine but distinct radial fabric. The ooids of this sample clearly show two-stage growth of concentric lamellae, dark ones insides and light ones outside. The sparry cement consists of fibrous crystal grew normal to the ooid surfaces and mosaic crystals in the central part of pore spaces although they are completely replaced by microcrystalline dolomites. Idiomorphic dolomite crystals ranging in size from 0.1 to $0.4 \mathrm{~mm}$ commonly occur around the nuclei of ooids.

Arenaceous oodolosparite beds are intercalated in quartzose sandstone and stromatolite beds. They are intermediate in component and texture between oosparite and dolomitic quartzose sandstone. Most of fine-grained detrital quartz grains are encrusted with ooid lamellae comprising two to several layers. Fig. 3 on Plate 2 is an example of arenaceous oodolosparite, in which sand grains are rather sparsely contained and many of them have ooid lamellae. The arenaceous oodolosparite occasionally contains micrite clasts probably of stromatolite origin.

Quartzose Sandstone

Sandstone beds ranging in thickness from a few decimeters to $3 \mathrm{~m}$ are 
intercalated at many horizons in the Khoraidi Formation. They are light-gray and can be distinguished in colour from the sandstones of the underlying Virkot and Chappani Formations. They are well stratified, fine- to medium-grained quartzose sandstone. Their grain-size frequency distribution commonly exhibits a bimodal pattern. Occasional wedge- and cross-beddings show palaeocurrents from $\mathrm{E}$ to $\mathrm{W}$ and from $\mathrm{ENE}$ to WSW, and some herringbone cross-beddings display alternate currents from $\mathrm{E}$ to $\mathrm{W}$ and from $\mathrm{W}$ to $\mathrm{E}$ (Fig. 10). Wavy and rippled-beds are not uncommon, but their frequency are lesser than in the Virkot Formation.

Pseudomorphs of gypsum crystals are commonly scattered in the sandstone at many levels. The crystals show a characteristic lozenge shape 0.5 to $3 \mathrm{~cm}$ long and 0.1 to $1 \mathrm{~cm}$ wide ( $\mathrm{Pl} .42$, Fig. 4). They are replaced by dolomite and other carbonate minerals, and include a fairly large amount of sand grains.

Top surfaces of the quartzose sandstone beds are sometimes coated with stromatolitic thin layers which form irregularly mounded shape. These coated sandstones were often eroded out and their fragments have been carried into the overlying sandstone beds and occasionally show an imbricate structure (Fig. 10). In addition, varying amounts of peloids, ooids, and reworked pebbles of stromatolite and dolomicrite are commonly contained in the quartzose sandstone. In case they are abundant, the sandstone gradationally changes into intraformational conglomerate.

\section{Rhythmite}

Thinly laminated shale beds with sandy laminae and bands are occasionally interbedded with the stromatolitic dolomite and quartzose sandstone beds of the Khoraidi Formation. Their thickness varies from $5 \mathrm{~cm}$ to a few meters, and the base and top of the beds are sharply bounded. These beds are alternatingly repeated papery shale and sandy siltstone with 0.5 to $3 \mathrm{~cm}$ thick, fine-grained sandstone at a few to several centimeter intervals (Pl. 44, Fig. 4). The sandstone bands exhibit wavy, flat, and lenticular bedding, laterally thin and thicken within a few tens of centimeter to one meter. The sandstone laminae and bands are quartzose, and have a calcareous and muddy matrix. Some papery carbonaceous laminae are contained in shale.

An interesting feature of these beds is to show bioturbation (Pl. 44, Fig. 4). Small sand-pipes and -tubules produced probably by burrowing organisms vertically or obliquely penetrate several laminae or sand bands. These are useful to determine the top surface of beds. Some of the shale layers are so highly bioturbated that the original stratifications are destroyed.

\section{c. Sedimentary Facies}

The Khoraidi Formation is unique among the sedimentary rocks in the Nepal Himalayas including the Tibetan Tethys sediments in consisting of a thick sequence of dolomitic stromatolite and oolite as is seen in Fig. 10, the detailed sketch of a part of the representative section of the formation. Modern stromatolite and oolite are known to occur in a very restricted environment; the former to the zone from intertidal flats to low-lying supratidal ponds and 
marshes, and the latter to intertidal flats to shallow subtidal shoal up to $5 \mathrm{~m}$ deep and coastal shallows of hypersaline lakes, where water agitation is generally strong. The lithologic assemlage and the compositions and textures of the constituent rocks of the Khoraidi Formation are comparable with Recent cabonate sediments and associated deposits in the coastal barrier and the coastal lagoons in the Abu Dhabi area (PURSER, ed., 1973), in the intertidal to supratidal zones of the hypersaline lagoon in Shark Bay (HoffmaN, 1976), and in the intertidal flat to supratidal marshes of Andros Island (HARDIE, ed., 1977). On reference to Recent deposits of these areas, the depositional environments of the Khoraidi are considered as follows.

The Khoraidi stromatolites are characterized by laterally linked, low dome- or tabular-shaped ones. These morphotypes indicate that they grew on intertidal flat where water-current and wave action were weak. The Khoraidi stromatolites are almost completely replaced by dolomite. This suggests that their growing area was probably adjacent to a sabkha or a hypersaline lake where the $\mathrm{Mg} / \mathrm{Ca}$ ratio in the interstitial water in the sediments was very much increased.

The stromatolites are alternately interbedded with sandstone which are accompanied with oolite, oncolite bed, intraformational conglomerate and rhythmite. Not a few beds of sandstone contain pseudomorphs of gypsum crystal. This indicate a high intertidal facies deposited under arid conditions. The rhythmite of sandstone and shale is considered to be a product of sandy intertidal flat. Quartzose sandstone with cross-bedding and herringbone structure can be attributed to lagoon channel deposits that were under influence of ebb- and flood-tide currents. The reworked intraformational pebbles must have been formed by migrations of meandering channels. The quartzose sandstone of which surfaces are thinly encrusted by knobby algal dolomite (Fig. 10) corresponds to channel-bank deposits covered by knobby algal crust. These algalcoated sandstone beds were eroded by migration of channels, and reworked flatpebbles were taken into the overlying sandstone bed (Fig. 10-5). The repetition of stromatolite, oolite and quartzose sandstone at short intervals indicates frequent fluctuation of depositional sites in the arid shoreline environments. To sum up the Khoraidi is a complex body built up at intertidal sandy flat, algal flat, sand beach and tidal channel as shown in Fig. 13.

\section{Saidi Khola Formation}

Type locality: Middle to lower stream of the Saidi Khola, $3 \mathrm{~km}$ east of Ramdighat (Fig. 4)

Thickness: $180 \mathrm{~m}$

The Saidi Khola Formation repeatedly crops out by folding in the area between the Bari Gad Fault and NBF of the Tansen Synclinorium (Fig. 4). It is also narrowly distributed in the eastern end area, $2 \mathrm{~km}$ north of the MBT. The exposures along the river side of the Saidi Khola is designated as the type section. 


\section{a. Stratigraphy and Lithology}

The formation consists chiefly of coarsely interlayered sandstone and shale with some packets of rhythmite (Pl. 44 Figs. 2 and 3). This rhythmic sequence can be divided into three parts on the basis of sand/mud ratio, and the thickness and colour of shale layers (Fig. 11).

The basal bed 2 to $3 \mathrm{~m}$ thick conformably rests on the Khoraidi stromatolite bed, and is composed of thinly interlayered beds of quartzose sandstone and black shale. The thickness of individual laminae is usually 1 to $4 \mathrm{~mm}$, but exceptionally reaches $1 \mathrm{~cm}$. The bedding surfaces between sandstone and shale layers is rather sharp and no marked grain-size change within a sandstone and a mudstone layer is observed. The shale is occasionally bioturbated, and sinuous to straight bored tubules are filled with quartzose sand that are often continues to the overlying sandstone bed (Pl. 44, Figs. 2 and 3). Sandy laminae are composed of well-sorted and well-rounded quartz grains and a minor amount of detrital muscovite. Some layers have a bimodal grain-size distribution of fine- and very fine-sand. Shales are composed of calcareous clay, much of which are altered to fibrous sericite. There are a few oolitic sandstone beds in the Virkot area, and stromatolitic limestone beds occur in the Angha Khola area. The conformable relation of the basal rhythmite to the Khoraidi stromatolite and the intercalation of oolite and algal limy shale in it indicate that the basal rhythmite bed must have been deposited in an intertidal environment in front of an algal marsh zone.

The lower and middle parts of the formation consist of coarsely interlayered sandstone and shale beds. The thickness and the sandstone/shale ratio gradually increase upward and some extraordinarily thick, more than $50 \mathrm{~cm}$, massive quartzose sandstone beds are rarely intercalated in the middle part ( $\mathrm{Pl}$. 47, Fig. 2). There are no marked lithologic differences between the middle and lower parts except that the shale of the middle part is green to silver-green and rarely light-purple. The thickness of sandstone and shale considerably

\section{Explanation of Plate 44}

Fig. 1: Thinly interlayered limestone (light) and red-purple and green calcareous slate (dark) of the Middle Member of the Ramdighat Formation at Dhanubas. Note the sharp cleavages which diagonally transect the bedding planes, and injection of mud along the cleavage planes.

2: Horizontally overturned, coarsely interlayered beds of quartzose sandstone and shale showing closely spaced bioturbation and mudcracks. Saidi Khola Formation along the Saidi Khola. Note lenticular- and wavy-bedding of sandstone, and sand tubules strained by tectonic deformation.

3: Thinly interlayered beds of quartzose sandstone and shale showing intense bioturbation and mudcracks. Saidi Khola Formation along the Saidi Khola. Note symmetrical wave-ripple with foreset laminae dipping toward left in the lower two sandstone beds.

4: Papery laminated rhythmite of sandstone and shale with some thicker sandstone lenses of the Khoraidi Formation at the river bank between Heklang and Virkot. Note the presence of many bioturbated sand tubules. 

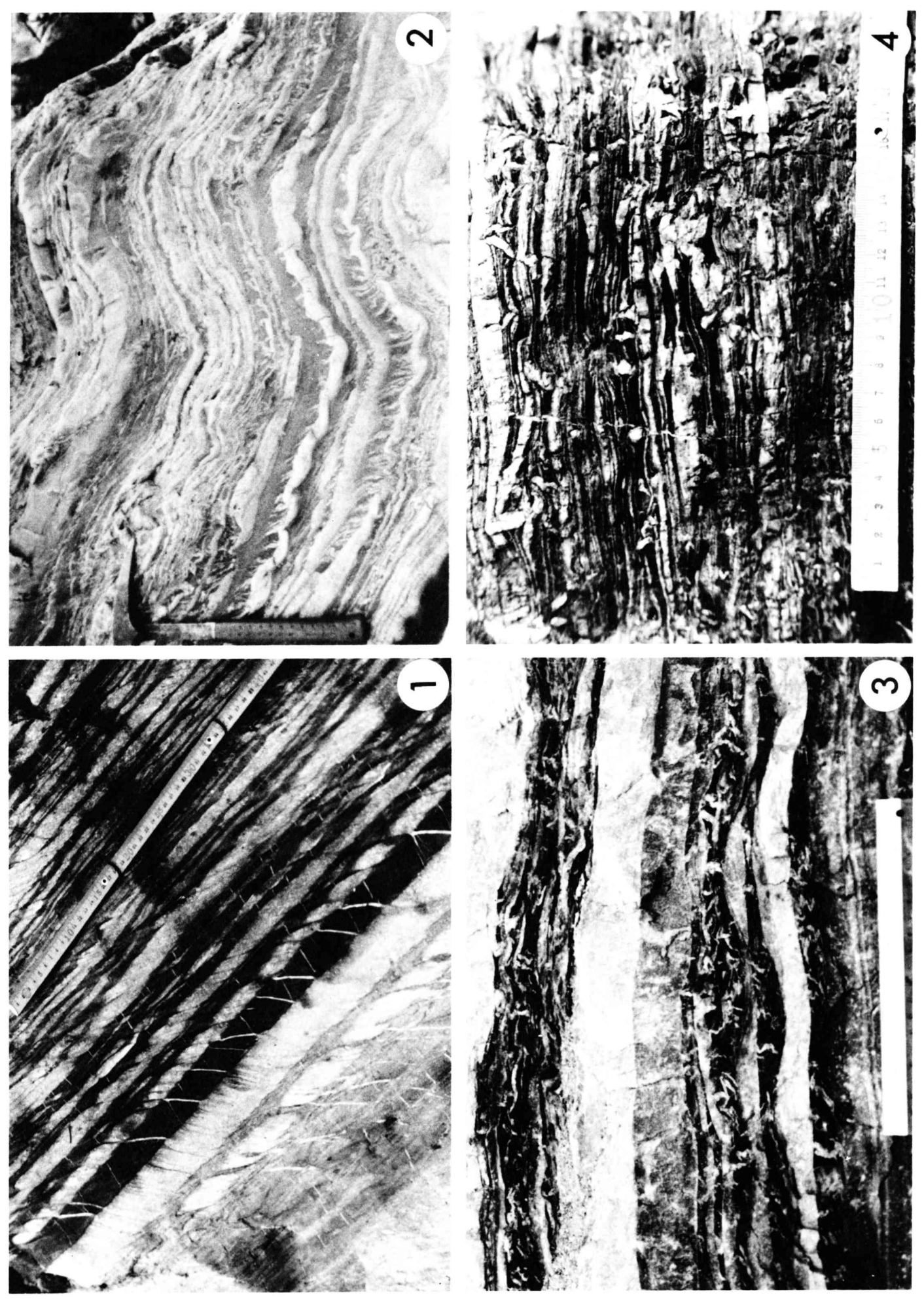

H. SAKAI: Kali Gandaki Supergroup 

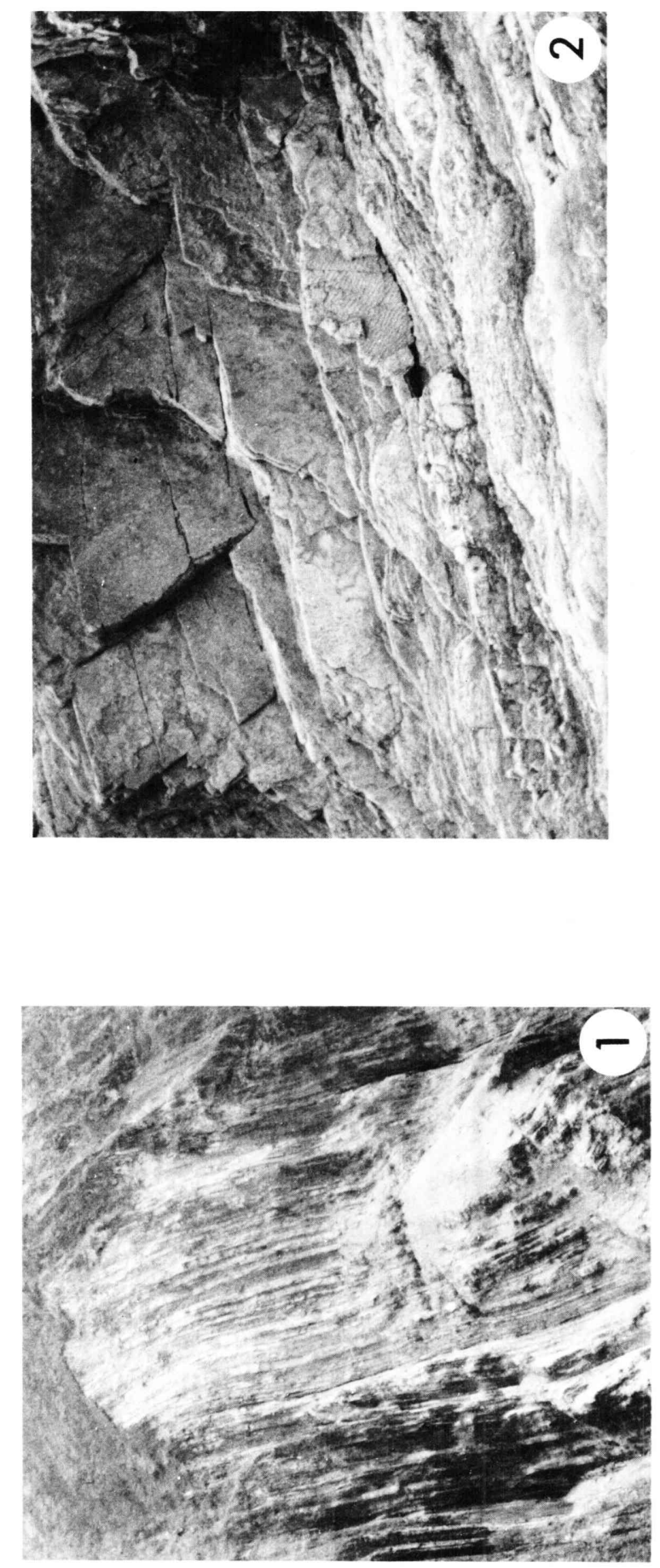
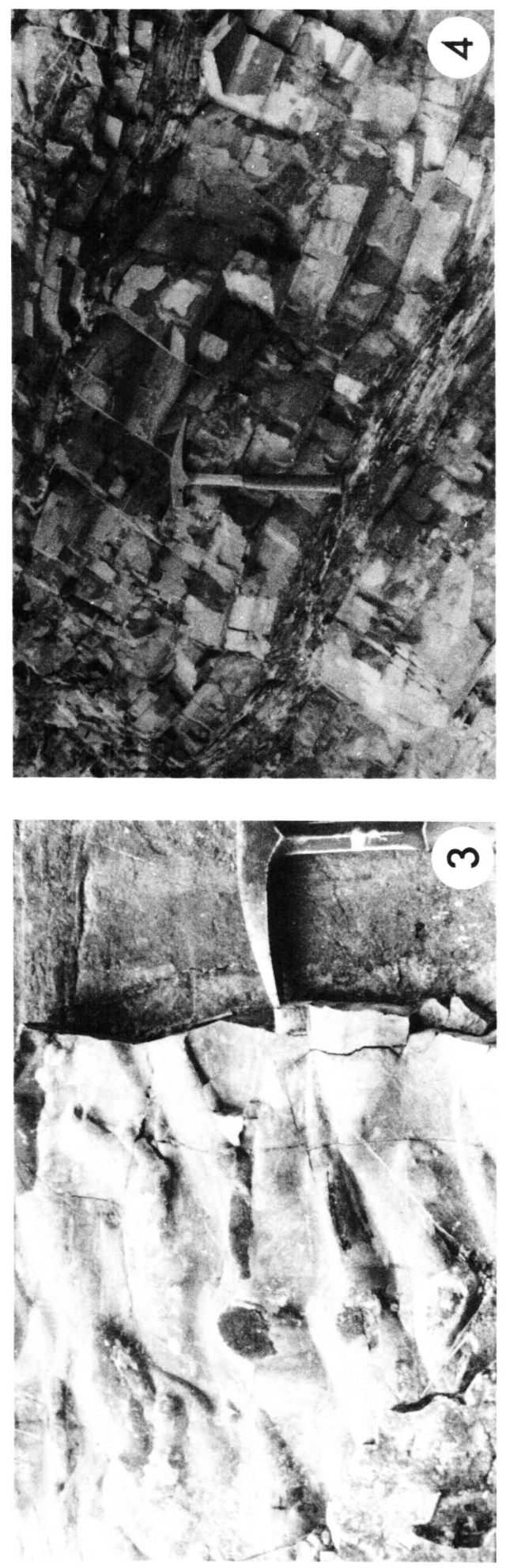

H. SAKAI: Kali Gandaki Supergroup 
varies within the sequence, but mostly ranges from 2 to $10 \mathrm{~cm}$. There occur several intercalations of rhythmite beds, in which the interlayered quartzose sand laminae are 1 to $5 \mathrm{~mm}$ thick (Pl. 44, Figs. 2 and 3). Bedding features of the lower and the middle part of this formation are seemingly similar to that of turbidite of flysch facies. Detailed observation demonstrates, however, that the sandstone beds are characterized by lenticular and wavy bedding as is seen in Pl. 44, Figs. 2 and 3. Oscillation ripple marks and ripple-drift cross-lamination are commonly observed, and those in the upper stream of the Nisti Khola demonstrate the palaeocurrent directions from NW to SE and from SE to NW. The sandstone beds more than $5 \mathrm{~cm}$ thickness can be usually traced laterally more than $10 \mathrm{~m}$, but some sandstone beds as thick as $20 \mathrm{~cm}$ wedge out within only $2 \mathrm{~m}$ (Pl. 44, Fig. 2). Bioturbation structures represented by sinuous and straight sand-tubes are also common (Pl. 44, Figs. 2 and 3, Fig. 17-d). The sandstone layers are composed of quartzose arenite whose petrographic characters have no differences from those of the quartzites of the underlying Virkot and Chappani Formations. They are well-sorted and wellrounded, and consist of fine-grained quartz and a minor amount of potassium feldspar and heavy minerals including tourmaline, zircon and garnet. The grainsize increases in proportion to the thickness of beds. Some beds contain reworked green-shale chips. The shale has almost been converted to fine fibrous rocks in which the sericites are arranged parallel to the cleavage. A minor amount of detrital quartz grains are sporadically observed.

In the upper part, the bed thickness gradually becomes thinner, and the uppermost part turns again to bioturbated rhythmite (Fig. 11). This rhythmite bed reaches 5 to $10 \mathrm{~m}$, and gradually changes into black slate of the Ramdighat Formation.

\section{b. Sedimentary Facies}

Thinly to coarsely interlayered bedding of sand and mud layers is known to be the characteristic bedform in the sediments of intertidal flats, where sandy layers are produced during a period of current activity and mud layers during a slag water period (REINECK and SINGH, 1980). Especially thinly interbedded rhythmites are reported to occur in the intertidal zone along the fringe of lagoons, estuaries and inner bays (Clifton, 1980; REINECK, 1967). The facies

\section{Explanation of Plate 45}

Fig. 1: A large cliff of the Middle Member of the Kerabari Dolomite along the Tinau Khola. Note platy bedform of thick dolomicrite beds. A kink-type parasitic fold is seen at the upper right of the photo.

2: Kerabari Dolomite showing platy bedform and wave ripple-marks. River bank at Kerabari along the Tinau Khola.

3: Flute casts that are preserved on the bottom surface of bedded dolomicrite of the Lower Member of the Kerabari Formation to the south of Kerabari.

4: Black, platy bedded, carbonaceous Riri Limestone on the river bank of the Tinau Khola, $150 \mathrm{~m}$ north of the MBT. 


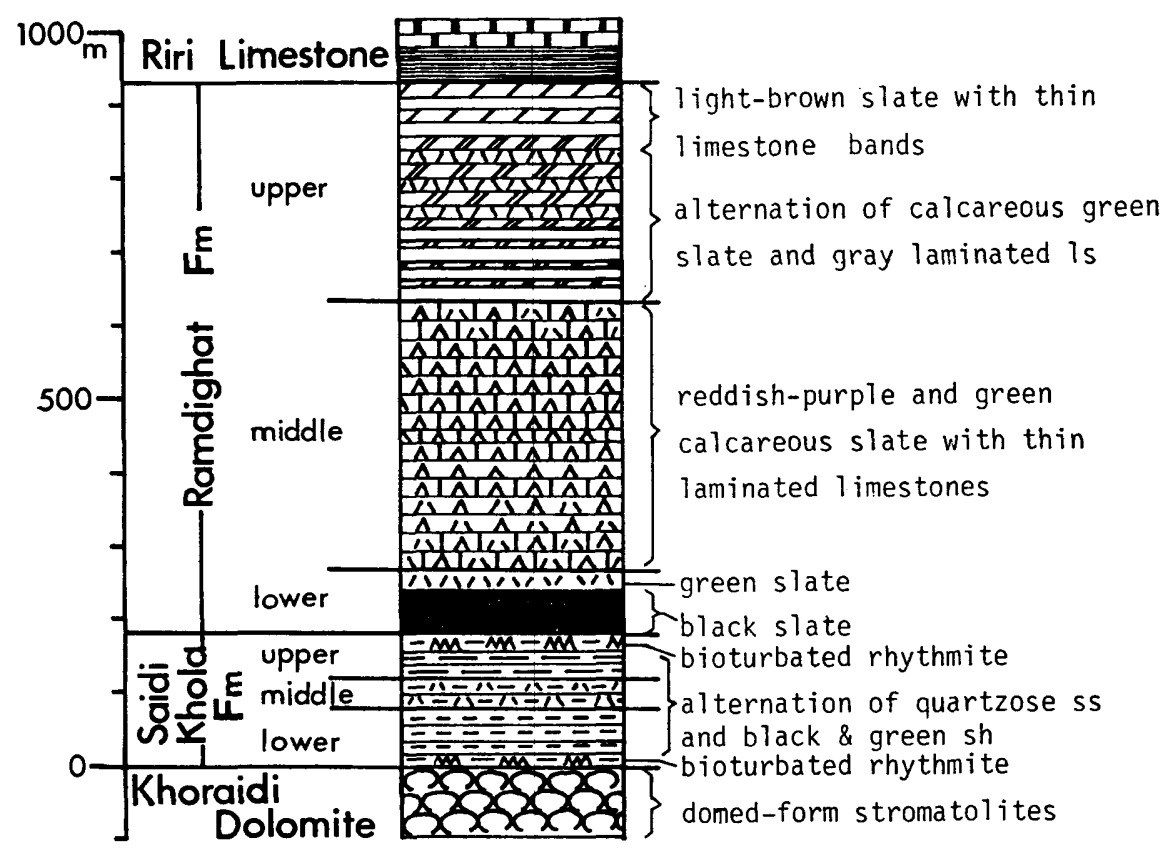

Fig. 11. Lithostratigraphic sequence of Saidi Khola and Ramdighat Formations and their stratigraphic relationship to Khoraidi and Kerabari Formation at Dhanubas.

change from the stromatolite of the Khoraidi Formation to the rhythmite of the basal part of the Saidi Khola Formation can be interpreted to represent the depositional environment change from an algal marsh zone to an intertidal zone where burrowing activity by organism was fairly thriving. The similar facies change is reported from the present Persian Gulf Coast (SHINN, 1983). It is known that the sand/mud ratio increases seaward in modern intertidal flat sediments (e.g. GADOW, 1970; REINECK, 1970-b), and that the flat is subdivided into three types; mud flat, mixed flat, and sand flat. The thickness change and the sandstone/shale ratio through the sequence of the Saidi Khola Formation probably implies the shifting of the environment from the marginal or near-shore flat to the low-water shoreline area of a lagoon or a bay.

The rhythmically interbedded unit of very thin to thin sandstone and shale layers of the Saidi Khola Formation is unique in that it appears at only one stratigraphic level in the Kali Gandaki Supergroup. Therefore the Saidi Khola Formation is useful as a stratigraphic marker bed which can be well traceable within the very thick sequence of the supergroup. Furthermore the contained bioturbated sandy tubules serve for the top and bottom determination of beds even in the intensely folded area (Fig. 17-d, Pl. 44, Fig. 2).

\section{Upper Kali Gandaki Group}

The Upper Kali Gandaki Group is distributed around the Tansen Synclinorium in the outer belt of the study area (Fig. 4). It is narrowly distributed in the lower valley area of the Andhi Khola in the inner belt.

This group consists of two formations; the Ramdighat and the Kerabari 
in ascending order. The Ramdighat is a varicoloured calcareous slate formation, and the Kerabari is monotonous beds of dolomite attaining $2000 \mathrm{~m}$ in thickness. The basal black limestone of the Kerabari Formation is separated from the main part as the Riri Limestone Member (Figs. 3 and 12). The Upper Group is, as a whole, characterized by thick carbonate rocks and its total thickness attains $2900 \mathrm{~m}$.

\section{Ramdighat Formation}

Type locality: The Ramdighat Formation is named from a village Ramdighat on the southern bank of the Kali Gandaki (Fig. 4). The rocks along the Upsa Khola, $1 \mathrm{~km}$ southwest of Ramdighat is designated as the type section. However, the formation is repeated by folding so many times there that the determination of the top and bottom of the formation is difficult. Therefore, the exposures along the upper stream of the Nisti Khola are designated as the reference section.

Thickness: $750 \mathrm{~m}$ in the reference section

The Ramdighat Formation is located in the area between the Bari Gad Fault and NBF of the Tansen Synclinorium (Fig. 4). In the northwestern area of Virkot and the Saidi Khola, only the lower black slate member repeatedly crops out by folding as a narrow belts. The formation is also exposed in the Muslang Khola and Angha Khola areas where the sequence is wholy overturned and intensely folded (Fig. 4). The best outcrop is seen in the upper reaches of the Nisti Khola, where the formation forms the south wing of the eastern end of the Tansen Synclinorium, and the top and base of the formation are clearly defined in the normal succession (Figs. 4 and 14-c). The small outcrops are found along the upper stream of the Badahare Khola at the southwestern corner of the Tansen Synclinorium, $200 \mathrm{~m}$ north of the MBT and along the upper reaches of the Kuru Khola northwest of Tansen.

This formation consists of calcareous argillite and a minor amount of thin limestone. Coarse clastic rocks are extremely rare. It is divided into three members: the lower black and green slate, the middle interlayering beds of varicoloured calcareous slate and limestone, and the upper green and gray calcareous slates with limestone laminae. These members are conformable and show gradual lithological changes.

\section{a. Lower Member}

The lower 80 to $90 \mathrm{~m}$ of the Ramdighat Formation comprises slate that is conformably underlain by the bioturbated rhythmite of the Saidi Khola Formation. Black slate forms the lower two-thirds and gradually changes into green slate of the upper one-third. Fine sandy laminae or bands rarely occur. Except these no bedding surfaces can be observed. A remarkable feature of the member is the closely spaced, sharp cleavage planes along which the rock splits into slaty plates. Fibrous sericite occurs along the slaty cleavages, then on weathering the slate assumes a silver luster. 
b. Middle Member

This member is characterized by marked colour banding of reddish-purple, pink and green calcareous slate and white limestone and a few-meters thick alternating units of specified colour combinations. The slate and limestone form rhythmic thin interlayering ranging in thickness from $1 \mathrm{~mm}$ to $5 \mathrm{~cm}$ (Pl. 44, Fig. 1). Limestone consists of light-coloured microsparite with dark-coloured micrite laminae, and does not contain any detrital grains. Varicoloured slate comprises silt- to clay-sized, angular to rounded quartz grains and muscovite flakes and have dirty microsparitic matrices. Fine carbonaceous matter and euhedral dolomite crystals occasionally occur along the laminae. Individual layers mostly exhibit bedding, although some beds of limestone are lenticular.

\section{c. Upper Member}

The Upper member is composed largely of calcareous and argillaceous slate and is subdivided into three parts (Fig. 11). The lower part is rhythmite that consists of thinly interlayered white limestone and gray calcareous slate. The limestone layers show a contorted ribbon-shaped structure due to segmentation by cleavages, and are completely converted into coarse aggregates of calcite. The slate layers are gray and calcareous, and are composed of silt to clay-sized detrital quartz and white mica and a fairly large amount of microsparite cement. The middle part is alternating beds of green to greenish-brown calcareous slate and rhythmite composed of brown to chocolate-brown calcareous slate and white limestone. The limestone of the rhythmite commonly shows discontinuous lenticular beds. The interbedded slate layers are 0.2 to $5 \mathrm{~cm}$ thick, and are occasionally bioturbated with the tubules which are filled with carbonate that is continued into the overlying limestone. They are composed of silt or clay-sized detrital quartz and fine carbonaceous matter, and contain micrite laminae. It is important that an intraclastic limestone layer 0.5 to $0.7 \mathrm{~cm}$ thick is intercalated in the slate of the reference section along the Nisti Khola. This layer is graded and is composed of intraclasts of micritized fine oolite, peloid limestone and rounded, sand-sized micrite, and a sparry calcite matrix. The limestone bands and laminae decrease in number upsection and the uppermost part consists entirely of dark brown, fine laminated calcareous slate with some black carbonaceous laminae.

\section{d. Sedimentary Facies}

The Ramdighat Formation is composed mostly of silt- to clay-sized material and is characterized by rhythmic, thin interbedding of limestone and calcareous slate. This sequence represents periodic supply of fine detrital grains in the continuous deposition of lime mud. The even layering and consistent grain-size frequency distribution of the clastic beds suggest that they were deposited by suspension from turbid water-layers. Bioturbated tubules in the slate indicate organic activity just after the deposition of argillaceous layer that contains abundant carbonaceous matter. A few sandy beds and a graded intraclastic layer with rounded-grains and oolite may be a storm-sand layer derived from a tidal zone. To sum up, the Ramdighat slate has possibly been deposited in a 
lagoon or large bay that was fringed with an intertidal flat with an algal marsh zone. The lithofacies changes from the Saidi Khola Formation to the Ramdighat Formation indicate a transgression or subsidence of the depositional basin.

\section{Kerabari Formation}

Type locality: Along the Tinau Khola near Kerabari village between Tansen and Butwal

Thickness: $2100 \mathrm{~m}$

The Kerabari Formation, the uppermost unit of the Kali Gandaki Supergroup, is most extensively distributed in the Tansen area. The cliff forming Kerabari Dolomite (Pl. 45, Fig. 1) forms a frontal ridge facing to the Mahabharat Lekh (Mahabharat and Lekh mean "Great India" and "Range", respectively, in Nepali) on the northern side of the MBT. It can be discontinuously traced from the far western Nepal to the eastern end of Nepal (UPRETI, 1980). In the study area, the Kerabari is distributed between the MBT and the Tansen Synclinorium with a width from a few hundred meters to more than $5 \mathrm{~km}$ (SAKAI, 1983, fig. 23). In this belt the beds moderately to steeply incline to the north in the central and western part, but are gently undulated by folding in the upper reaches of the Angha and Purba Kholas. The Kerabari also crops out on the northwest and the north of the central part of the Tansen Synclinorium, where it generally dip south (Fig. 4; SAKAI, 1983, fig. 23). To the north of the Bari Gad Fault the formation is exposed in the Andhi Khola area, in two belts ranging in width from a few hundred meters to $2 \mathrm{~km}$. There is no distribution of the Kerabari Formation to the north of these belts.

The main part of the Kerabari consists of laterally persistent, thick-bedded dolomite, which forms inaccessible ridges and cliff, as shown in Pl. 45, Fig. 1, in the areas of steeply dipping beds and meagre flat terraces or gentle hills in the areas where the beds gently incline. These topographic features enable to trace this formation easily even to distant places.

The Kerabari Formation conformably rests on the Ramdighat Formation. The basal black limestone is designated as the Riri Member. The lithologic change from the Ramdighat slate to the Riri Limestone is gradual. The Kerabari Formation, except the basal Riri Limestone, is composed entirely of monotonous, light-gray, bedded dolomite with varying bed thickness ranging from $10 \mathrm{~cm}$ to more than $50 \mathrm{~cm}$. The inaccessibility to large outcrops and the monotonous lithology and great thickness over $2000 \mathrm{~m}$ of the formation make it difficult to get a complete lithostratigraphic section. However, the Kerabari may be roughly divided into four parts including the Riri Member based on the lithologic sequence along the type section. This division can be applied for the whole study area (Fig. 12).

\section{a. Riri Limestone Member}

Black, platy-bedded, argillaceous limestone and slate, 100 to $150 \mathrm{~m}$ thick, are recognized at the basal part of the Kerabari Formation in the whole study area. This member is named after a village of Riri where the whole sequence of this 
member is exposed (Fig. 4). Good exposures of the Riri Limestone are also present along the river side of the Tinau Khola to the south of a village Kerabari, although the lower part of the member is truncated by the MBT there (Fig. 14-A; SAKAI, 1983, fig. 23). Around Simaldanda in the eastern margin of the study area, the member crops out most widely covering the mountain sides (Fig. 4). The member is narrowly exposed along the Andhi Khola in the north central area.

The lower several decimeters of the member consists of black, calcareous slate and a minor amount of black limestone, the latter gradually increases toward the upsection. The upper one hundred meters is a sequence of black, thin platy-bedded, argillaceous and carbonaceous limestone, which are composed principally of spary calcite and a minor amount of detrital quartz and white

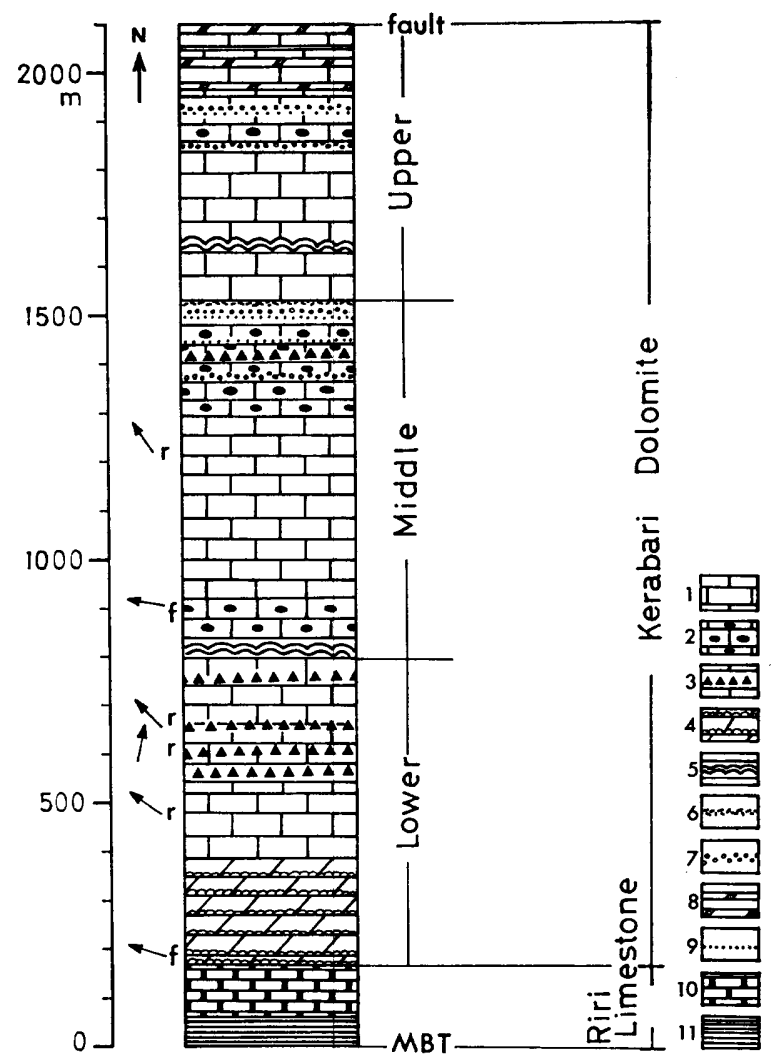

Fig. 12. Lithostratigraphic sequence of Kerabari Formation along type section around village Kerabari along Tinau Khola. 1. bedded dolomicrite; 2. chert band and nodule; 3 . intraformational dolomicritepebble conglomerate; 4 . sheet-formed stromatolite; 5 . dome-shaped dolomitic stromatolite; 6 . intraformational stromatolite-pebble conglomerate; 7. oolite; 8. red-purple dolomitic shale and pink dolomicrite; 9. dolomitic quartzose sandstone; 10 . black laminated to banded limestone; 11. black laminated calcareous slate, $r$ : ripple mark, f: flute cast. 
mica. Thin sections reveal that the dark tone of the laminations results from very fine carbonaceous laminae disposed at 0.05 to $0.2 \mathrm{~mm}$ intervals. The contained quartz is 0.02 to $0.05 \mathrm{~mm}$ in size and its roundness is variable. Fine fibrous sericite is formed along the cleavages.

In the uppermost part of the member, black limestones are commonly intercalated with thin shales. The limestones entirely consist of sparite without any detrital grains, and the shales comprise detrital quartz, muscovite and carbonaceous matter. The limestone may probably be of algal origin, as a small knobby structure is observed on their surfaces. As a result of differential weathering, the soluble limestone and the resistant shale give rise to ridges and grooves, respectively. These jagged weathered surfaces are of distinctive feature by which this member is easily distinguishable from other formations.

\section{b. Kerabari Dolomite}

The main part of the Kerabari Formation, named the Kerabari Dolomite, is divided into three parts (SAKAI, 1983, 1984), although this subdivision is tentative. The coarsely interlayered beds of black limestone and shale at the top of the Riri Limestone gradually decrease their thickness and change into thinly interlayered beds of a few to $1 \mathrm{~cm}$ thick, gray dolomite and thinly laminated shale, some of which can be called rhythmite. These beds are 100 to $200 \mathrm{~m}$ thick. The dolomite occasionally shows a small knobby structure probably of algal origin. The corresponding unit around Riri Bazar and Argeri is not dolomitized and remains as limestone. The following 100 to $200 \mathrm{~m}$ comprises a few to $10 \mathrm{~cm}$ thick-bedded dolomite that has ripple marks and parallel-laminae. The upper 200 to $300 \mathrm{~m}$ of the lower part is characterized by many intraformational dolomicrite-pebble conglomerate which alternates with bedded dolomicrite. The conglomerate is composed of rounded to subrounded dolomicrite granules and pebbles (Pl. 46, Fig. 4), and sometimes form amalgamated beds which attain a maximum thickness of $7 \mathrm{~m}$. The interbedded dolomite occasionally has ripple marks including oscillation ripples, and flute casts (Pl. 45 Figs. 2 and 3).

The Kerabari Dolomite in the upper reaches of the Badahare Khola is commonly accompanied by $1 \mathrm{~mm}$ to $5 \mathrm{~cm}$ thick, carbonaceous shale partings and thin beds in a $50 \mathrm{~m}$ platy bedded dolomicrite sequence of the lower part. The carbonaceous shale is somewhat micaceous, occasionally graded, and sometimes contain tiny plant remains 1 to $3 \mathrm{~mm}$ size. I already pointed out that these carbonaceous shales are worthy for the consideration of the age of the Kali Gandaki Supergroup (SAKAI, 1983).

The middle part is composed principally of 5 to $50 \mathrm{~cm}$ thick, evenly bedded dolomicrite (Pl. 45, Fig. 1). Its lower limit is tentatively placed at the lowest bed of domed-form, laterally linked dolomitic stromatolite. Individual domes average 50 to $70 \mathrm{~cm}$ in diameter and their laminae are somewhat cherty. Stromatolites occur at several horizons in the basal part. The middle part is characterized by intercalation of thin chert beds in the lower and upper parts (Fig. 12). They are black to dark gray and as thick as 1 to $5 \mathrm{~cm}$, and occur as thin platy beds, lenticular beds with load casts and ripple-marks, and nodules (Pl. 46, Figs. 1 and 2). They are usually found, but in part are rhythmically interlayered 
with platy bedded dolomite ( $\mathrm{Pl}$. 46, Fig. 2). It is important that there are several intraformational pebble conglomerate beds that include subangular chertpebbles and very coarse quartz sands besides dolomicrite pebbles. Some of them exhibit distinct graded bedding and are associated with flute casts ( $\mathrm{Pl}$. 45, Fig. 3 ). The other type of intraformational pebble conglomerate that is composed mostly of flat or curled pebbles having a stromatolitic structure is also present. A big float of domed stromatoloites was detected from the valley along the type section. It seems to have been derived from somewhere in the middle part. Oolitic dolomite 5 to $15 \mathrm{~cm}$ thick is found at several horizons in the upper part (Fig. 12). They are completely dolomitized, and the concentric structure is hardly recognized. The size of ooids ranges from 0.1 to $0.5 \mathrm{~mm}$ and is smaller than those of the Kerabari Formation. One of the oolite beds shows small-scale cross- and parallel-bedding along which grain-size sorting occurs, and shows marked current activity at the depositional site. Many of the dolomicrite beds of the upper section of the middle part show marked graded bedding from fine dolomicritic sandstone to dolomicrite. They are accompanied by thin carbonaceous shale at the top of each graded bed. These beds commonly show lenticular- and wedge-bedding.

The upper part is also composed of platy- and wedge-bedded dolomicrite with various bed-thickness up to $50 \mathrm{~cm}$. In lithologic characters it resembles the lower and middle parts, but the occurrence of pink to light-purple shale and dolomite with agate granule conglomerate is unique to the upper part. These beds can be traced all over the study area and are useful as stratigraphic marker beds. In the upper reaches of the Barangdi Khola to the north of Tansen, there occurs steeply cross-bedded pink dolomite (Pl. 46, Fig. 2) and an intraformational conglomerate that contains rounded flat-pebbles of oolite, stromatolite, dolomicrite and quartz grains.

The upper limit of the Kerabari Formation is uncertain due to the truncation by faults and erosion. The Kerabari is overlain with a distinct disconformity by the basal conglomerate of the Sisne Formation of the Lower Gondwanas (SAKAI, 1983), which contain pebbles and cobbles of gray chert, dolomicrite and oolite derived from the underlying Kerabari Dolomite.

\section{c. Sedimentary Facies}

The basal Riri Limestone is considered to have been deposited in a lagoonal environment where fine micritic mud and carbonaceous matter were rhythmically supplied. Scattered subrounded detrital quartz grains may have been originated from wind-blown sands. The rhythmite unit at the lowest part of the Kerabari must be the deposits in an intertidal flat where growth of algal mat and deposition of micritic mud rhythmically occurred.

The Kerabari Formation is unique in the whole Himalayas in having a very thick, monotonous sequence predominantly of dolomicrite. It is known that Recent dolomite occurs in restricted environments, e.g. supratidal flat of the Andros Island, Bahamas (SHINN, et al., 1965), sabkhas of the Persian Gulf (IlliNG, et al., 1965), ephemeral lakes or remnants of lagoon near the Coorong Lagoon, South Australia (ALDERman, 1965), and others which are all in the 
tropical to subtropical, or arid areas. Dolomite crystals form by replacing aragonite in warm magnesium-rich brines, in which magnesium/calcium ratio ranges from 10 to 15 . Recent dolomite deposits are accompanied by shrinkage mud cracks, gypsum pseudomorphs, thin interlayering of wind-blown sand, clay and evaporite layers, and so on. Kerabari Dolomite is, however, lacking in these features, but instead contains oolite and stromatolite beds. Most remarkable is the platy bedding and the lateral consistency of thickness and lithology. The graded beds and marked flute casts suggest that the dolomicrite is of detrital origin, transported and derived by current from such original depositional places as supratidal flat or sabkha. The common occurrence of symmetrical oscillation and asymmetrical current ripple marks show that dolomicrite beds were deposited in depths wave-action reaches. Thus their depositional environment is possibly an inner shelf in front of arid carbonate shoreline. The frequent intercalations of intraformational dolomicrite-pebble conglomerate support this interpretation, because well-rounded and well-sorted pebbles show that they were subjected to moderate transportation. Chert breccias contained in the conglomerate also indicate that they were eroded and reworked from chert beds. On the other hand occurrence of stromatolite and cross-laminated oolite beds represents their deposition in an intertidal to a shallow subtidal zone. Flat pebbles of oolite in the intraformational conglomerate suggest their redeposition.

In the upper part of the Kerabari Formation, there occur wedge- and crossbedded dolomite, and reddish-coloured dolomitic shale; the latter is similar to

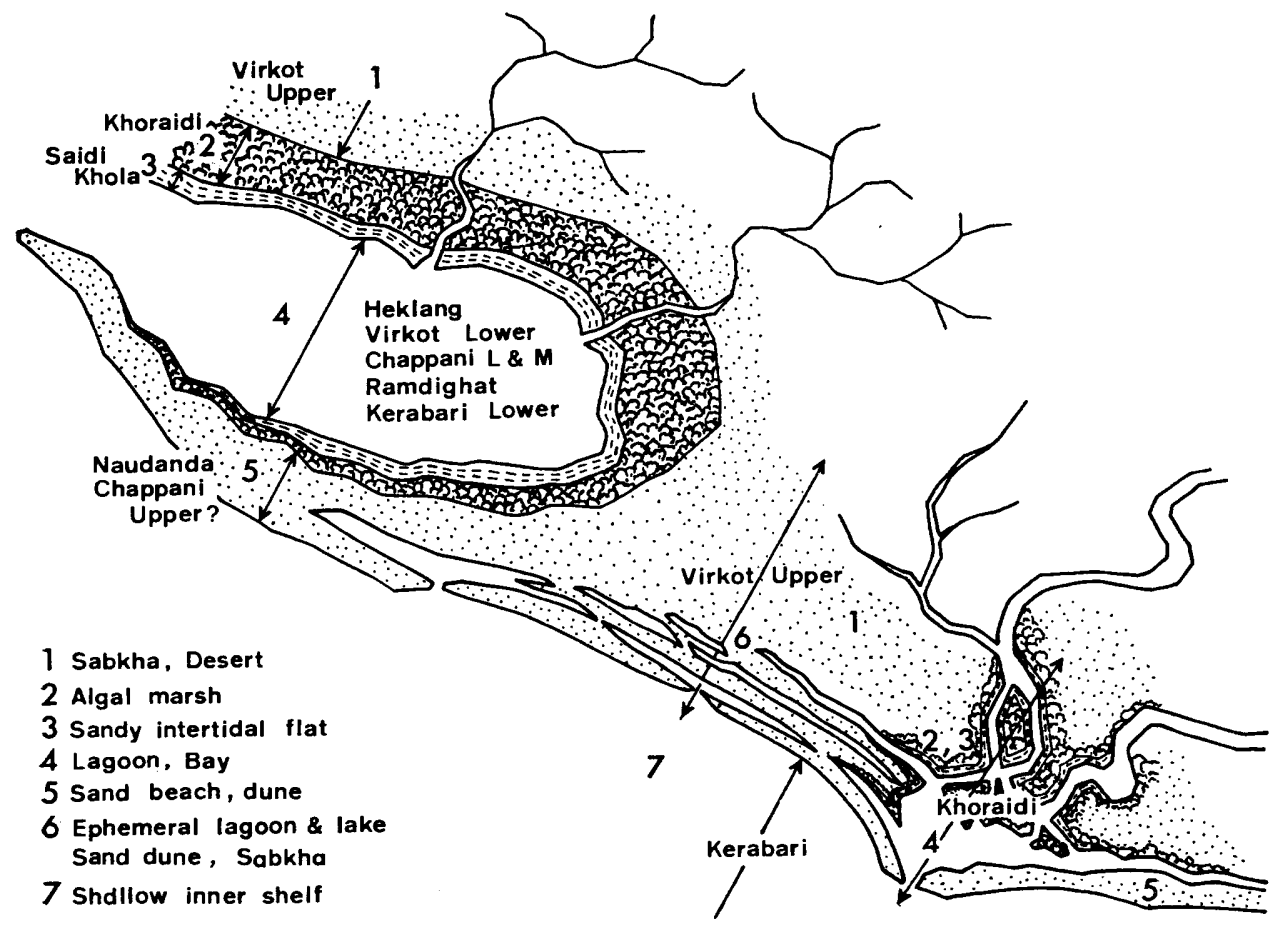

Fig. 13. Reconstruction of depositional environments of formations of Kali Gandaki Supergroup. 
that of the Virkot Formation. Sedimentary facies changes from monotonous bedded dolomite of the middle member to the wedge- and cross-bedded ones of the upper member suggest that the depositional environment became shallower.

Throughout the whole sequence of the Kerabari Formation, subrounded to rounded, fine- to coarse-grained detrital quartz laminae and bands are sporadically contained, and carbonaceous shale partings are commonly intercalated. The former indicates that there must have been desert on hinterland from where aerial sands were transported by wind. The latter suggests the presence of plant-vegetated marsh zone on the rear side of the depositional basin of the Kerabari Formation. Directional sedimentary structures indicate persistent palaeocurrents from $\mathrm{S}$ to $\mathrm{N}$ and from $\mathrm{E}$ to $\mathrm{W}$ (Fig. 12).

General depositional facies of the Kerabari Formation shows that the Kerabari was deposited under shallow marine conditions such as inner shelf and intertidal zone. Water depths are considered to have varied within a few tens of meters. Therefore the great thickness of the Kerabari implies the persistent subsidence of the depositional basin. The thick and continuous sequence without marked lateral thickness and lithofacies changes indicates that the formation was deposited in a widespread basin on a stable basement. As a whole the facies change from the Ramdighat to the Kerabari indicates transgression, and that from the lower part to the upper part of the Kerabari reflects general shallowing of the basin with episodic fluctuations of water depths.

\section{Geologic Structure}

\section{A. Major Structural Division}

The Lesser Himalayas in western Central Nepal is divided into two major tectonic belts as in Kumaon; the outer and inner belts. In the study area, the boundary between both belts can be drawn along the Bari Gad Fault, because both belts are structurally very different from each other. The outer belt on the south is 10 to $20 \mathrm{~km}$ wide, and the inner belt on the north as broad as 60 to $70 \mathrm{~km}$ (Fig. 2). The former has undergone intense deformation, and resulted in highly complex structures represented by imbricate structures, klippen, recumbent folds and tight overturned folds. Therefore, it is difficult to establish a stratigraphy of the rocks of the outer belt unless careful structural analysis is made. The latter is subdivided into two parts by the Phalebas Thrust. The

\section{Explanation of Plate 46}

Fig. 1: Chert nodules in clean, homogeneous dolomicrite of the Middle Member of the Khoraidi Formation on the river bank of the Tinau Khola.

2: Platy, lenticular, nodular and wedge-shaped cherts (darker part) in thin- to medium-thick bedded dolomicrite of the Middle Member of the Kerabari Formation on the river bank of the Tinau Khola.

3: Cross-bedded dolomite of the Upper Member of the Kerabari Formation near the site of Fig. 1.

4: Intraformational dolomicrite-pebble conglomerate of the Lower Member of the Kerabari Formation. Note their roundness and sorting. $\times 7$. 

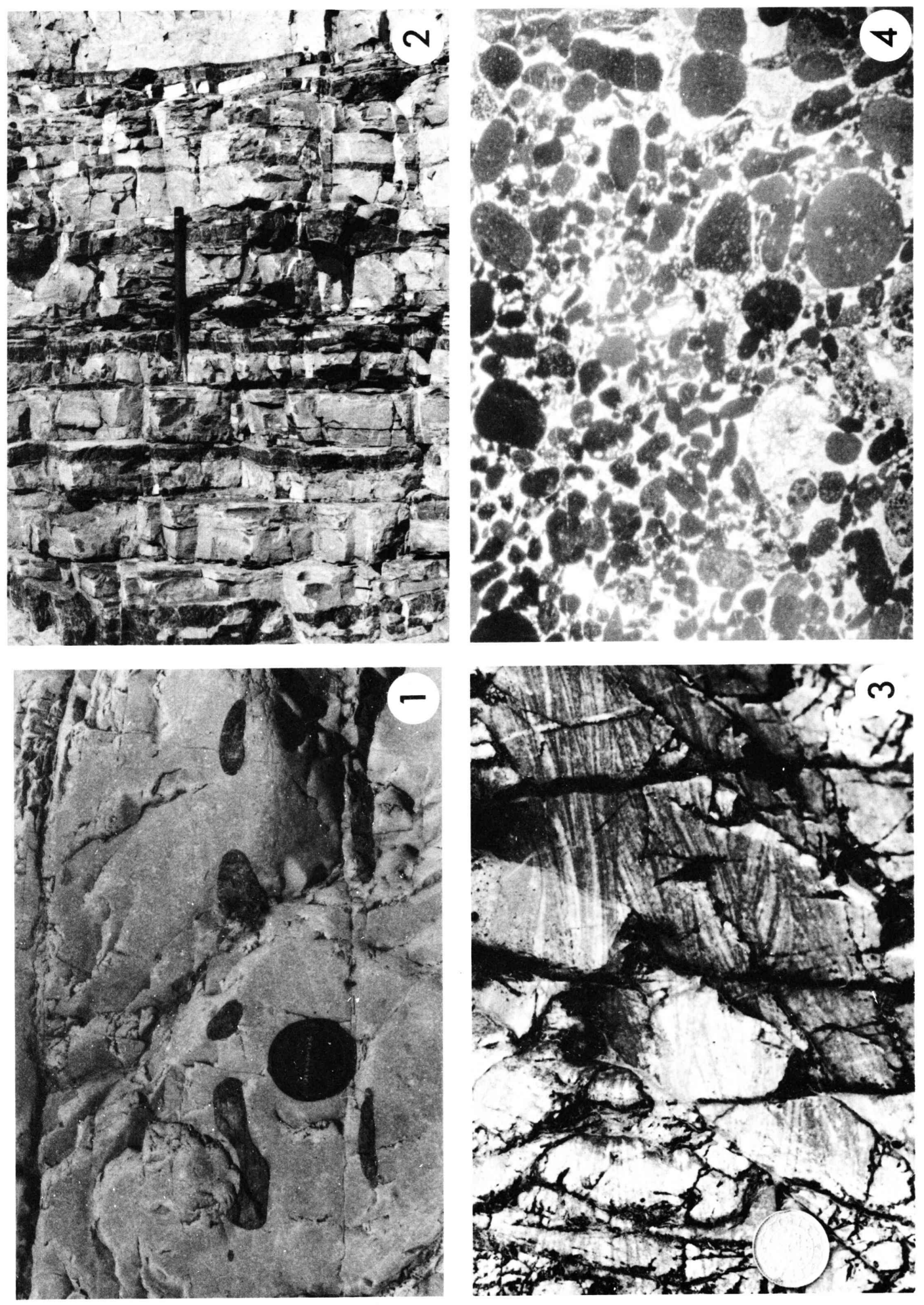

H. SAKAI: Kali Gandaki Supergroup 

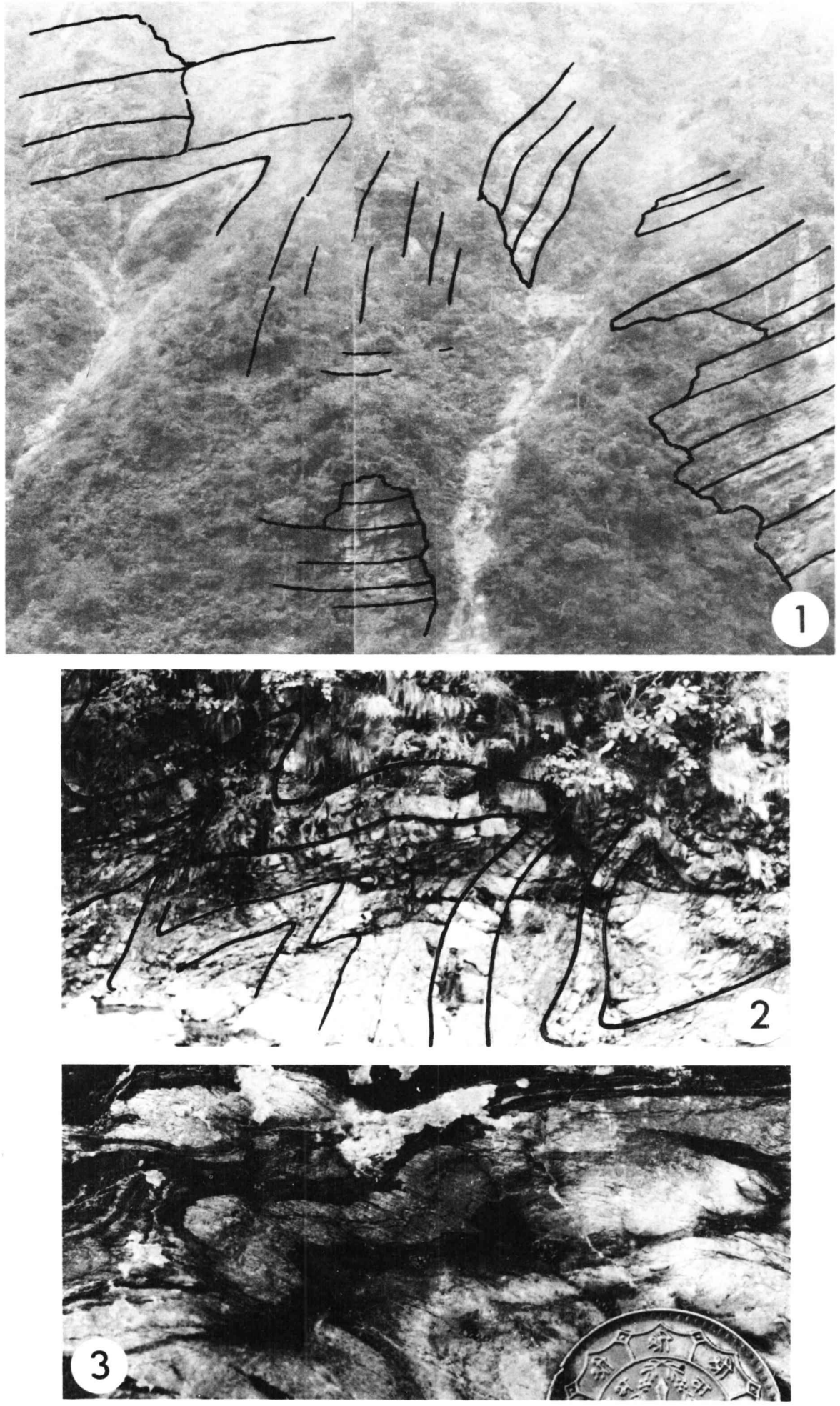

H. SAKAI: Kali Gandaki Supergroup 
southern part is characterized by broad open folds and high-angle normal faults with a great vertical displacement. The northern part consists of the lower Kali Gandaki Group, which constitutes broad Kuncha-Gorkha Anticlinorium (ОнтA et al., 1973), and which thrusts upon the southern part along the Phalebas Thrust. The northern tract of the inner belt forms a highly tectonized and metamorphosed zone, "Main Central Thrust Zone (MCT Zone)" (ARITA et al., 1982). The lower limit of the MCT Zone is bounded by a shear zone made up of blastomylonitic augen gneiss (Ulleri gneiss of PECHER and Le FoRT, 1977; MCT I of ARITA et al., 1982), and the upper one (MCT II of ARITA et al., 1982) by the Himalayan gneiss (Fig. 2). The metamorphic grade increases from the MCT-I up to garnet-biotite schists of the MCT II.

The outer belt of the study area consists of three belts; the Tansen Synclinorium, Angha Khola Recumbent-Fold Belt and Khoraidi Fold Belt from south to north. The former two are bounded by each other with the Northern Boundary Fault (NBF) and the latter two, in turn, are bounded with the Ramdi Fault. These three belts seem to have formed a pair of huge, southerly verging recumbent anticline and syncline on the rear side of the MBT (Fig. 19). The Angha Khola Recumbent-Fold Belt overthrusts upon the Tansen Synclinorium and forms the Palpa Klippe (Figs. 4 and 14; SAKAI, 1983, fig. 23). In front of the Palpa Klippe, the Tansen Group forms a distinct imbricate structure (SAKAI, 1983). The Angha Khola Recumbent-Fold Belt is cut by the Ramdi Fault on the rear side. The Khoraidi Fold Belt exhibits a normal sequence in the central part of study area, but it again shows overturned stratigraphy in the Waiga area (Fig. 4).

The southern part of the inner belt is longitudinally faulted at intervals of 1 to $6 \mathrm{~km}$, and has resulted in a kind of horst and graben structure forming a relatively lowland area, the so-called Midlands, along the Kali Gandaki and Andhi Khola. Great vertical displacement along each fault is estimated on the basis of the stratigraphic position.

\section{Explanation of Plate 47}

Fig. 1: The second order, Z-shaped, parastic folds of the Khoraidi dolomitic stromatolite on the inverted limb of the Angha Khola. The gently dipping beds are fully overturned and those of steeper dips show a normal sequence. The location and sketch of this outcrop are shown in Fig. 17-e.

2: The third and fourth order, Z-shaped folds of the Saidi Khola Formation in the Khoraidi Fold Belt along the Saidi Khola. A scale is indicated by a man standing at the center of the photo.

3: Small-scale similar folds of the Middle Member of the Ramdighat Formation. Note the axial plane cleavages and microlithons. The dark bands are red-purple calcareous shale and the lighter ones limestone. 


\section{B. Major Boundary Faults}

1. Main Boundary Thrust

The southern margin of the Lesser Himalayas is clearly separated from the Siwalik Hills by the Main Boundary Thrust that is even now active (HAGEN, 1980 ; NAKATA, 1982). The MBT can be traced by a sharp lineament of valleys and characteristic land forms like pressure ridges and fault terraces. Throughout the study area, the thrust plane dips north at angles of 70 to 90 degrees. Along the Tinau Khola and its tributaries, the Riri Limestone, the basal member of the Kerabari Formation, is in fault contact with massive sandstone of the Middle Siwaliks. The black limy slate and banded limestone are so strongly sheared that they lost their original bedding planes in the width ranging from 50 to $100 \mathrm{~m}$. Quartz segregation bands occur along cleavages in part. Micaceous massive sandstone and purple shale of the Middle Siwaliks are also sheared and tectonized to form boudinages within the width of $50 \mathrm{~m}$ from the MBT. A fault clay 10 to $15 \mathrm{~cm}$ wide occurs along the thrust plane. The rocks of the Kali Gandaki Supergroup along the MBT often exhibit gentle folds that seem to have been caused by the MBT.

\section{Tansen Synclinorium Boundary Faults}

The Tansen Group in the Tansen Synclinorium is circumscribed by the underlying Kali Gandaki Supergroup with a sole thrust that is represented by Southern Boundary Fault (SBF) of upthrust sense along the southern side and Northern Boundary Fault (NBF) of downslide sense on the northern side. The SBF is accompanied by a intensely sheared zone, while the NBF has a sharp fault plane as already described by SAKAI (1983).

\section{Ramdi Fault}

The Ramdi Fault separates the northern half of the outer belt into two belts; overturned Angha Khola recumbent fold belt and Khoraidi tightly folded belt. The fault can be traced $25 \mathrm{~km}$ from Rani Ghat to Arbhsing (Fig. 4). It is topographically expressed by linear strike valleys and fault cols, and land-slides have occurred along it at several places. The southern wall is downthrown relative to the northern wall with a sharp fault plane dipping south at angles of 40 to 55 degrees. In the tributaries of the Ramdi Khola, it is marked by a zone of fault breccia $50 \mathrm{~cm}$ wide in addition to fault gouge of $1 \mathrm{~m}$ wide. At the north of Virkot the Ramdi Fault is represented by a $10-\mathrm{m}$ wide, strongly sheared zone containing sandstone blocks mixed with shale slivers of the Saidi Khola Formation. This fault seems to die out in the Arbhsing area.

\section{Bari Gad Fault}

The Bari Gad Fault has a component of vertical displacement, and the Andhi Formation on the northern side is relatively uplifted at least a few hundred meters.

Especially noteworthy is that the Bari Gad Fault has topographic evidence to indicate right-lateral strike-slip movement in Recent time. It is marked by abrupt bending of streams, displaced river-terace deposits along the Kali Gan- 
daki and offset ridges along the fault. In the middle course of the Bari Gad river to the northwest of the study area (Fig. 2), horizontal displacement of more than $200 \mathrm{~m}$ and vertical one of $15 \mathrm{~m}$ are reported by NAKATA et al. (1984). They also report that relative displacement deduced from tectonically produced landforms is downthrown to the northeast, and consider that commencement of Recent active faulting does not date backs to the formation of the Higher Terrace. The horizontal displacement, which is marked by river offset on the Higher Terrace of the Kali Gandaki, shows the same right-lateral slip as in the Bari Gad area. However, the vertical displacement deduced from the offset of bed rocks shows one to the opposite direction; the Andhi Formation on the north is relatively raised up against the Virkot Formation. This means the difference of movement directions between the Recent time and the past geologic period. No good exposures of the Bari Gad Fault which mark the very contact between the Andhi Formation on the north and the Heklang Formation on the south were found in the study area. A subsidiary fault, which cuts the river terrace deposit, was observed near a village Hungi. The Andhi Formation adjoining to the Bari Gad Fault has been metamorphosed in higher grades than in other parts to phyllite and semi-schist, and kink bands are commonly developed. This zone attains a width more than $1 \mathrm{~km}$ in part. Near Heklang calcareous slate and limestone of the Heklang Formation show tight folding in a zone of $200 \mathrm{~m}$ along the fault. Landslides of high terrace deposits and bed rocks occur along the fault zone and have given rise to depressed landforms. The landslide to the northeast of Waiga is as large as about $1 \mathrm{~km}$ in width. A gentle, open valley around the village Birgha is possibly caused by landslide. A large meander of the Kali Gandaki from Cheharmi to Ashiewachaur appears to be related to the right-lateral movement along the Bari Gad Fault.

The eastern extension of the Bari Gad Fault can be traced to the south of Keladighat along the southern margin of the terrace of the Kali Gandaki. A straight lineament is also observed along the northern margin of the terrace of the Kali Gandaki in the area from Andighat to Maiti Khola. This suggests that the Bari Gad Fault bifurcates in the eastern area. SAKo et al. (1973) and ARITA et al. (1982) named "Kali Gandaki Fault" for the eastern extension of the Bari Gad Fault to this area and applied the name "Bari Gad-Kali Gandaki Fault" for the whole extension of the fault. However, this usage is nothing but hampered. In this connection, it should be remarked that their Kali Gandaki Fault is lined through positions different from the Bari Gad Fault in the present paper.

\section{Keware Fault}

The southern part of the inner belt is segmented to several narrow zones by a series of high angle faults, of which most remarkable is the Keware Fault which forms the contact between the youngest Kerabari Formation and the oldest Andhi Formation. This fault is also expressed by some topographic features like a fault col, but lineament is not so clear as in the Bari Gad Fault. The fault plane dips south at angles of 70 to 90 degrees. The bedded dolomite of 
the Kerabari Formation is intensely deformed and disjointed along and near the fault, and around the village of Khani the deformed zone ranges 50 to $100 \mathrm{~m}$ in width. The other faults that subparallel to the Keware Fault in the north also have large vertical displacements.

\section{Phalebas Thrust}

The Phalebas Thrust separates the inner belt into two belts; the northern belt that consists of the Lower Kali Gandaki Group and the southern belt of the Middle and Upper Kali Gandaki Groups (Fig. 2). The Phalebas Thrust corresponds to the sole thrust of the "Chail Nappe" (Fuchs and FraNk, 1970), which was considered to be the eastern extension of the "Chail Nappe" in the Simla-Garhwal Himalayas lying at a long distance, more than $600 \mathrm{~km}$ from this area. The Kuncha Formation of monotonous phyllite and the Naudanda Quartzite thrust upon the Middle and Upper Kali Gandaki Groups at angles of 20 to 30 degrees (Fig. 5). The Naudanda Quartzite along the Phalebas Thrust is completely recrystallized, and weathers porous rocks. The basic rocks intercalated in the Quartzite are pervasively sheared, and lubricous cleavage planes seem to have played an important role for the overthrusting.

\section{Outer Belt}

\section{Tansen Synclinorium}

The outermost part of the Lesser Himalayas in the Tansen area forms Tansen Synclinorium which embraces the Tansen Group of the Gondwanas and Tertiary rocks (Figs. 2 and 4; SAKAI, 1983, fig. 23). As geologic structures of the Tansen Group were already described (SAKAI, 1983), characteristic structures of the Kali Gandaki Supergroup which occupies the outer part of the Synclinorium are described in this section.

The Kali Gandaki Supergroup of the southern wing of the Synclinorium shows a rather simple geologic structure as compared with that of other areas and homoclinally dip north in general. The Tansen Group is surrounded by the Kerabari Formation on the north-central, western and southern sides. In the central area of the southern side, the Kerabari Dolomite inclines to the north at high angles of 70 to 90 degrees, but are overturned in part. They gradually decrease the dip towards east and west (SAKAI, 1983, fig. 23). The stratigraphic succession along the Nisti Khola in the eastern corner of the study area was designated as the type section of the Middle and Upper Groups as already noted. However, the sequence from the Chappani Formation to the Riri Limestone along the upper reaches of the Badahare Khola is decreased in thickness to less than one-third $(500 \mathrm{~m})$ of the type section by a series of thrusting. In the Kurman and Jhumsa Khola areas mappable, thin slices of the Virkot and Kerabari Formations are tectonically inserted in the Sisne Diamictite. Their boundary faults are surprisingly sharp as if were cut by a razor, and all of them are high-angle up-thrusts from north to south.

Asymmetric folds of various scales commonly occur on the southern wing of the Tansen Synclinorium. Their wave-lengths range from $200 \mathrm{~m}$ to a few tens 


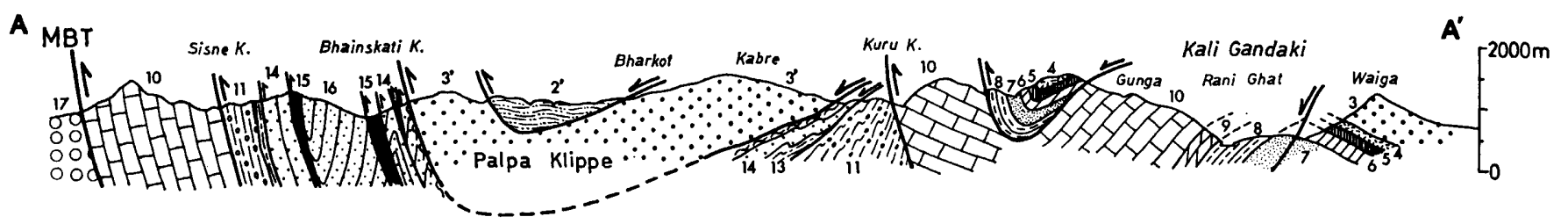

B

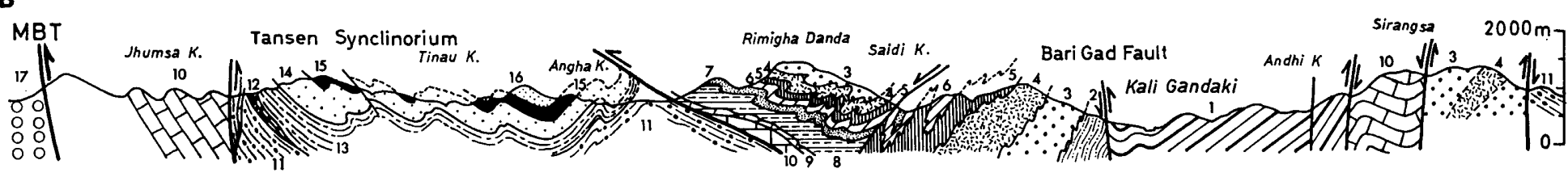

C
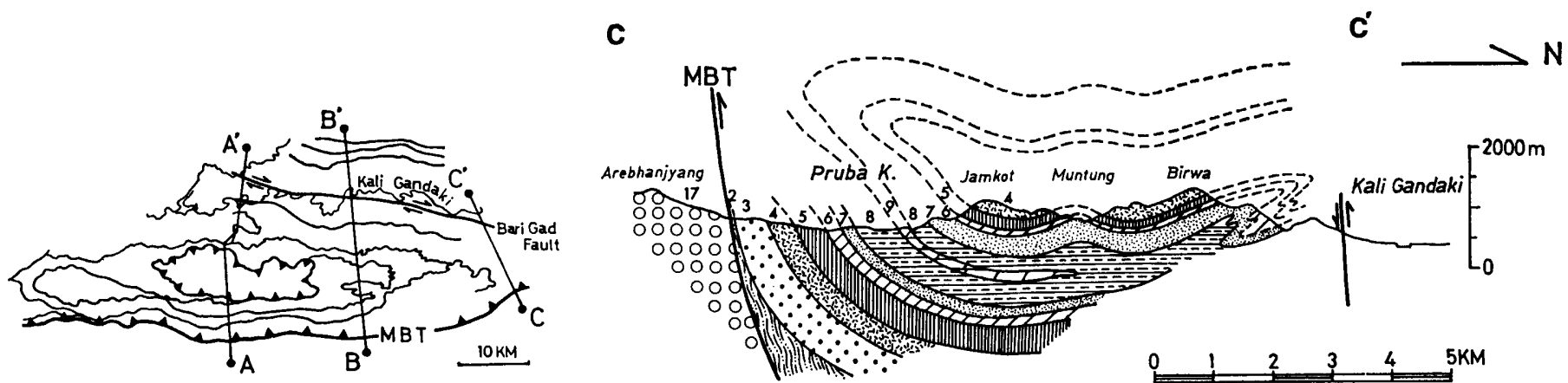

Fig. 14. Cross-sections of outer belt and southern half of inner belt of Lesser Himalayas in western Central Nepal, based on SAKAI (1983) and Fig. 4 of this paper. 1 to 10; Kali Gandaki Supergroup, 11 to 16; Tansen Group; 17; Siwalik Group. The formation names are as follows; 1. Andhi, 2. Heklang, 3. Virkot, 4. Chappani, 5. Khoraidi, 6. Saidi Khola, 7. Ramdighat/ Lower), 8. Ramdighat (Middle and Upper), 9. Riri, 10. Kerabari, 11. Sisne, 12. Aulis Basalt, 13. Taltung, 14. Amile, 15. Bhainskati, 16. Dumri, 2. Heklang and others, 3. Virkot and others. 


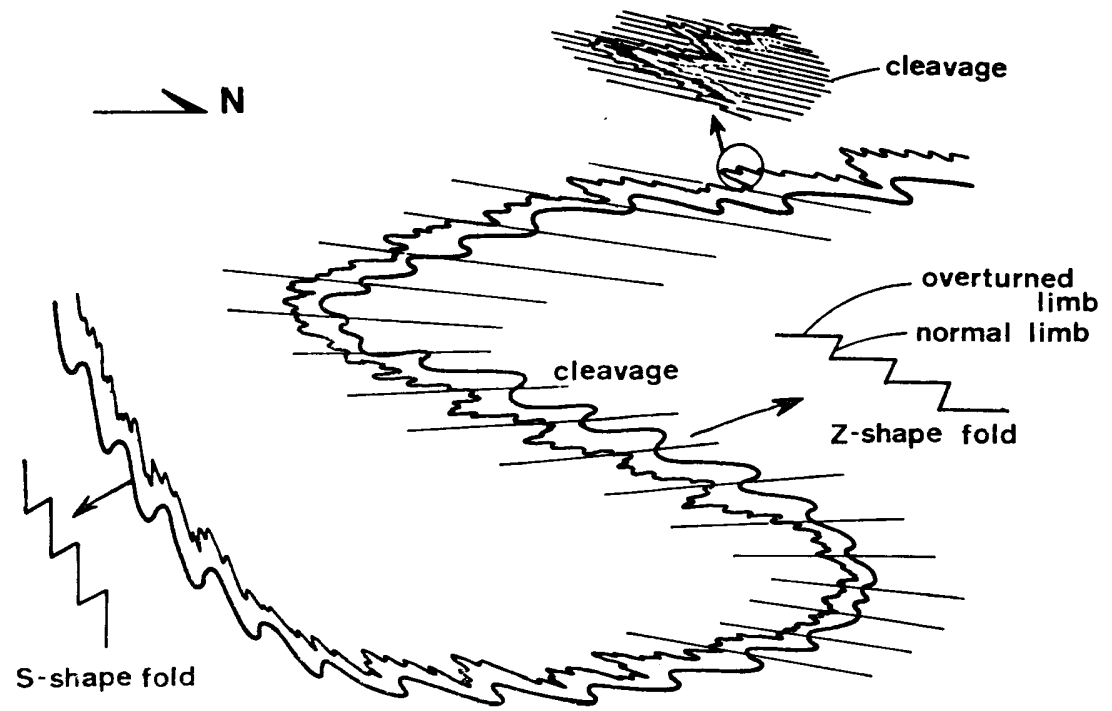

Fig. 15. Simplified profile of the Tansen Synclinorium and Angha Khola Recumbent Fold.

of centimeters. These folds show a southerly verging S-fold regardless of their scales, and are considered to have been formed as parastic folds on the southern limb of the Tansen Synclinorium (Fig. 15).

\section{Angha Khola Recumbent-Fold Belt}

Gently dipping overturned beds are extensively distributed on the northern side of the Tansen Synclinorium. They constitute an inverted limb of a large recumbent fold, herein named Angha Khola Recumbent-Fold Belt. This belt, together with the Tansen Synclinorium forms a complex fold belt extending 20 $\mathrm{km}$ in width along the Himalayan front.

The recumbent-fold belt is 4 to $5 \mathrm{~km}$ wide and can be traced $40 \mathrm{~km}$ in length from Pokharathok to Jamkot (Fig. 4). The inferred axial plane of the fold dips NNE at angles of 10 to 30 degrees and strikes WNW-ESE. Whole rocks more than $2000 \mathrm{~m}$ thick from the Virkot Formation to the Riri Limestone exhibits a reversed sequence on the northern flank of the Angha and Purbha Khola valleys. The typical sequences can be observed on the mountainside around villages of Kuwadi and Jhakhedi between the Angha Khola and Rimigha Danda (Figs. 4 and 14). Detailed cross-sections based on 1:5000 route maps and characteristic minor structures along the sections are shown in Figs. 16 and 17. Gently northward-dipping beds are exposed on mountainsides at altitudes of 750 to $1750 \mathrm{~m}$. Sedimentary structures such as cross-bedding, graded-bedding, load cast, scour and fill structure, and bioturbation structures including sand-pipe and -tubules in the beds evidently show that the sequence is totally overturned (Figs. 16 and 17; Pl. 44, Fig. 2 and Pl. 48, Fig. 1). The most definitive criterion for the overturned structure is the presence of upside-down stromatolites of the Khoraidi and Chappani Formations (Figs. 16, 17-c, e; Pl. 48, Fig. 1). There ex- 


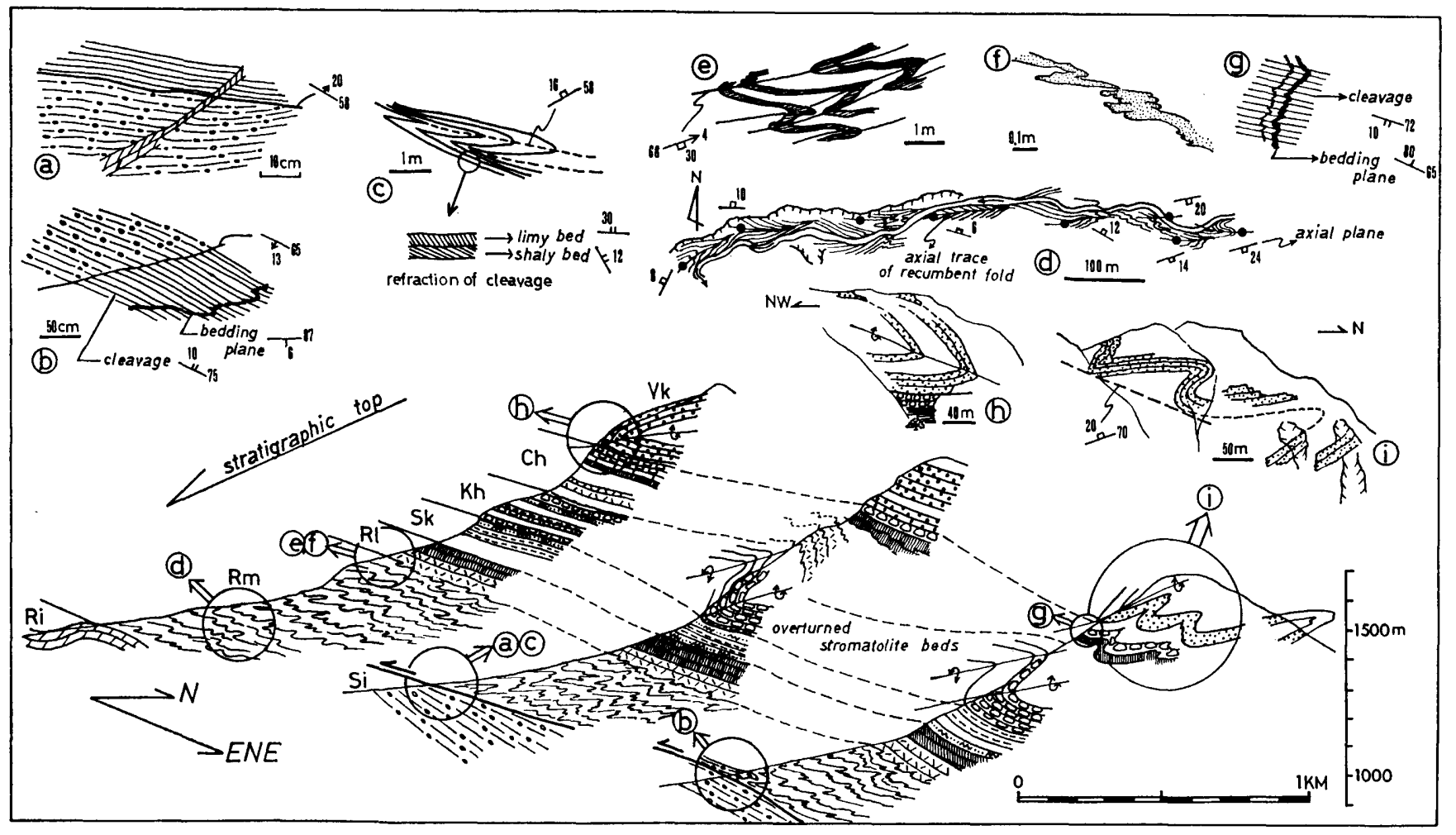

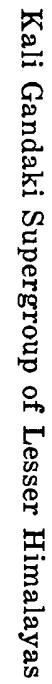

Fig. 16. Cross-section combined from three upper streams of the Angha Khola around village Kuwadi, and sketches of minor structures along section. Right-hand sides of all sketches point north, otherwise stated. 


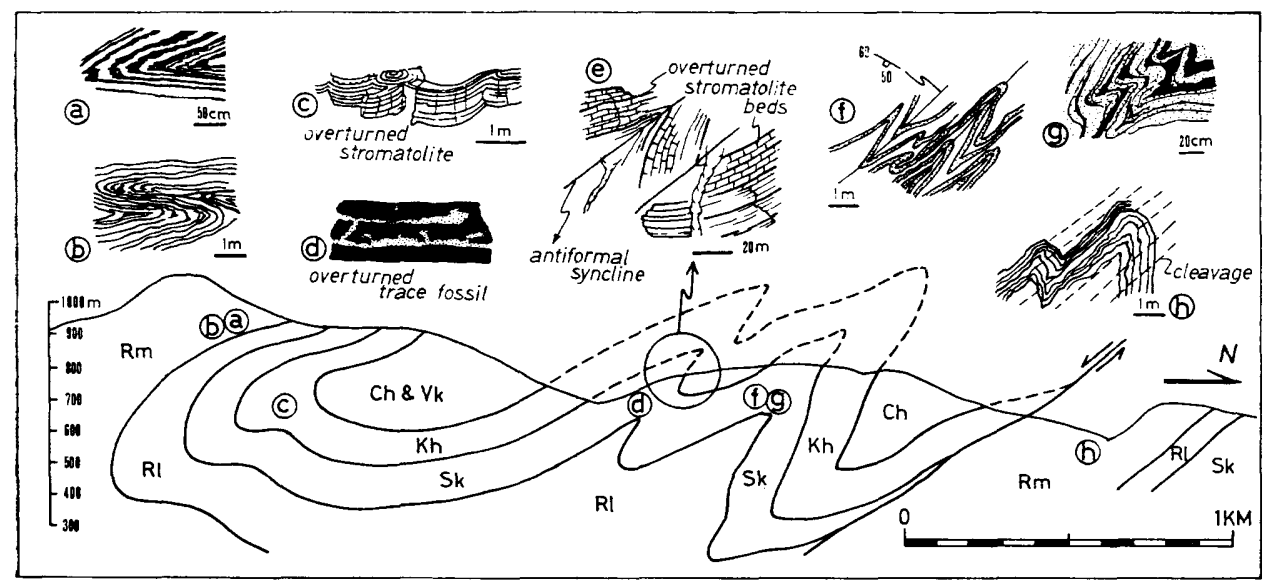

Fig. 17. Detailed profiles of inverted limb of Angha Khola Recumbent-Fold and its relation to Ramdi Fault along the Angha and Ramdi Khola. Important minor structural features and sedimentary structures ( $a$ to $h$ ) are shown as sketches. Right-hand sides of all sketches point north, otherwise stated.

poses a set of antiformal syncline and synformal anticline which consist of stromatolite beds of the Khoraidi Formation along the lower reaches of the Angha Khola (Fig. 17-e, Pl. 47, Fig. 1).

The overturned structures of this area are also revealed by the attitude of folds and the cleavage-bedding plane relationships. There are folds of various scales which commonly have a Z-shape in cross section (Figs. 15 and 17). They show ones constructed of a gently dipping, longer, overturned limb and a steeply dipping, shorter limb with a normal sequence (Figs. 15, 16 and 17). The interlimb-angles are 30 to 60 degrees in average and become smaller in argillaceous rocks. The wave-length ranges from a several hundred meters to a fraction of a few millimeters, and the ratio of amplitude to wave-length ranges from one-half to one-fourth (Fig. 15). Thick, massive Virkot Quartzite displays a megascopic fold structure on the mountainside near Jhakhedi (Fig. 16-i). The Ramdighat slate forms a numerous recumbent folds accompanied with parasitic folds of various scales (Fig. 16-d, e, f). Both formations show the same type of folding with NNE vergence and Z-shape in spite of their lithologic differences, and their enveloping surfaces dip north at angles of 20 to 30 degrees. These structural features suggest existence of a large-scale recumbent fold, and the beds represent its inverted limb. All beds of the recumbent fold are more or less intensely cut by slaty, fracture and crenulation cleavages. The cleavage planes have a consistent attitude, and are subparallel to the axial planes or longer limbs of folds (Fig. 15). Therefore they are probably subparallel to the axial plane of the recumbent fold. The axial part of the folds can be seen in a small outcrop, because the cleavages intersect the bedding planes at a right angle as shown in Fig. 16-g. When we estimate the axial planes of folds using cleavage planes, it should be noticed that cleavage planes refract dip angles in every different lithologic boundary as shown in Fig. 16-c. 
Around Jamkot and Dhanubas in the eastern end of the study area, the limbs of the recumbent fold and synclinorium are connected without interposition of the overlying Tansen Group and the boundary fault (Figs. 3 and 14). The Tansen Group, embraced in the Tansen Synclinorium, narrows eastwards and disappears in the Jamkot-Sangdig area (Fig. 4). The main axis of the synclinorium can be traced near the Purba Khola, along which the sequence from the Virkot Formation to the Riri Limestone is symmetrically distributed. The rocks on southern bank of the Purba Khola show a normal sequence, while those on the northern bank are reversed (Fig. 4). Therefore a gently dipping, tightly folded profile is estimated (Fig. 14-c). The synformal anticlines and antiformal synclines are deduced, as the beds are all overturned (Fig. 4). Horizontal to gently dipping, overturned beds of the Chappani Formation form open valleys with gentle relief around Siluwa and Chappani, and those of the Virkot Formation form continuous ridges and steep mountainsides from Nayar to Virkot.

The Angha Khola Recumbent-Fold is interrupted by a thrust around Pokharathok (Fig. 4), where the overturned sequence from the Virkot Formation to the Riri Limestone discordantly thrusts up on the top bed of the Kerabari Formation. This discordance can be attributed to the difference of physical characters between the Kerabari Dolomite and the overlying rock sequence. As the structure of the Kerabari Formation is uncertain, further discussion cannot be done as for the boundary thrust. However, the sliding on the major lithologic boundry-plane and nearly along the bedding planes seem to play an important role to the formation of the fold and thrust belt of the Lesser Himalayas in western Central Nepal. Abrupt thinning and thickenning of beds and units often occur in various scales. For example, the sequence from the Virkot Formation to the Riri Limestone in Pokharathok is about half of that of the type section at the eastern corner of the study area (Figs. 4 and 14). The thickness of a limestone bed of the Ramdighat Formation varies very much as shown in Fig. 17-a. Sandstone and shale beds of the Saidi Khola Formation show a distinct pinch and swell structure; the shale beds are much thicker on the steeply dipping limbs of folds than on the gentler limbs (Fig. 17-f, g). These variation of thickness can be attributed partly to the ductile flow of an incompetent bed under a high confining pressure and partly to the sliding on the bedding surfaces.

Sun cracks and intraformational shale-pebbles often show preferred orientation that are subparallel to cleavage planes (Pl. 48, Fig. 2). Some of stromatolites are also strained and have lost their original forms. These strained structures show that the sequence was laid under strong simple shear stress.

The Sisne Diamictite lying along the northern margin of the Tansen Synclinorium is evidently involved in the Angha Khola Recumbent Folding. The Ramdighat Formation or the Riri Limestone usually thrusts upon the Sisne Diamictite (Fig. 16-a). However, the Sisne Diamictite rarely overlies the Riri Limestone and is bounded by a sharp fault plane (Fig. 16-b). The cleavages of these two formations have the same attitude, although they are separated from each other by a fault (Fig. 16-a, b). It means that part of the Sisne Diamictite was involved in a tectonic activity which have formed the Angha Khola Recum- 
bent Fold. This is also indicated by the low-angle cleavages of the Sisne Diamictite along the northern margin of the Tansen Synclinorium in the central area.

\section{Palpa Klippe}

The Middle Kali Gandaki Group overthrusts upon the Tansen Group in the central part of the Tansen Synclinorium and forms the Palpa Klippe (SAKaI, $1983,1984)$. The klippe is $20 \mathrm{~km}$ long from east to west direction and up to 7 $\mathrm{km}$ wide from north to south. It forms a gentle synform whose axial trace nearly corresponds to that of the Tansen Synclinorium (SAKAI, 1983, figs. 22 and 23). The sole thrust of the klippe dips north at high angles along the southern margin and gently inclines south on the rear side. It is surprising that the basal part of the klippe is brecciated only a few tens of centimeters, on the other hand the footwall rocks of the underlying Tansen Group has undergone strong shearing and forms a tectonic melange zone 10 to $200 \mathrm{~m}$ thick around the Klippe (SAKAI, 1983, figs. 22 and 23). A good example of the sole of the klippe along the frontal margin of the klippe is seen at a village Kialong on the northern bank of the Bhainskati Khola, where the basal part is brecciated only 5 to $20 \mathrm{~cm}$ wide from the thrust plane, while shale of the Bhainskati Formation is intensely sheared to form a melange zone $40 \mathrm{~m}$ wide (Pl. 48, Fig. 4). A distinct contrast of deformation style and degree between the base of the klippe and top of the autochthonous rocks indicates their great ductility differences when the klippe was formed.

The Palpa Klippe is composed of two thrust sheets of different lithologies; the major part of the lower sheet is comparable with the Virkot Formation and the upper sheet with the Heklang Formation. Both sheets are separated by a distinct thrust (SAKAI, 1983, figs. 22 and 23), which shows a deformation style similar to the sole thrust of the Palpa Klippe; at the western margin of the upper thrust sheet, the overlying calcareous phyllitic slate of the Heklang Formation maintains sharp bedding planes, on the other hand pink to purple dolomitic shale and white dolomite of the Virkot Formation at the top part of the lower thrust sheet are truncated by many thrusts to form a imbricate zone $30 \mathrm{~m}$ wide. The frontal part of the upper thrust sheet is characterized by kink

\section{Explanation of Plate 48}

Fig. 1: Horizontally overturned stromatolite of the Khoraidi Formation near Ramdighat.

2: Shale-pebbles of the Virkot Formation showing the rearrangement and preferred inclination by simple shear stress. The same type of deformation are shown as strained muderacks (Pl. 42, Fig. 2) and strained stromatolites.

3: Sole thrust of the Palpa Klippe at Kialang in the upper reaches of the Bhainskati Khola. See text for explanation.

4: Slaty cleavage facing parallel to the plate and vertically intersecting fine, dark-coloured lamination of the Heklang Phyllite of the Palpa Klippe along the Tinau Khola. 

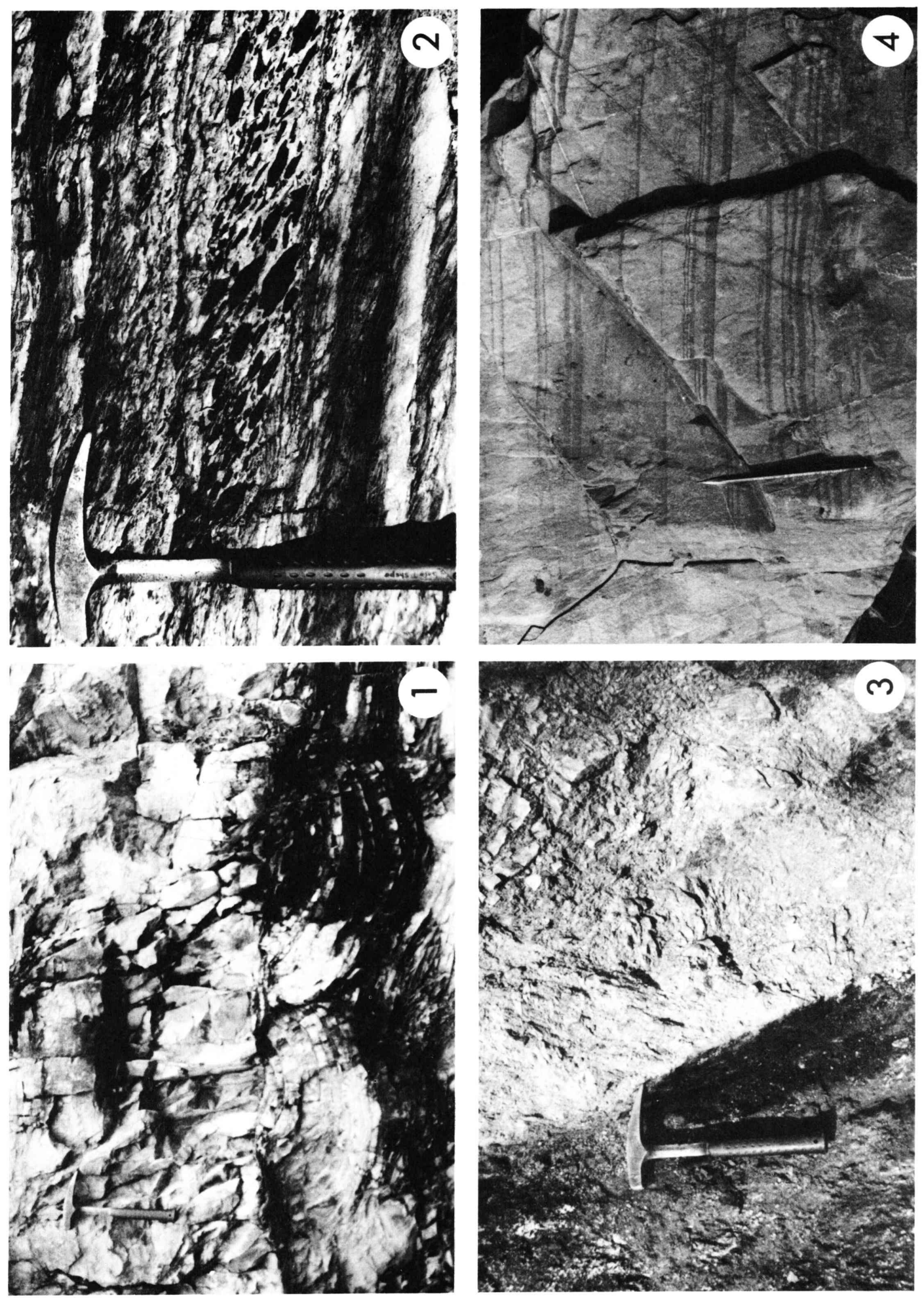

H. SAKAI: Kali Gandaki Supergroup 

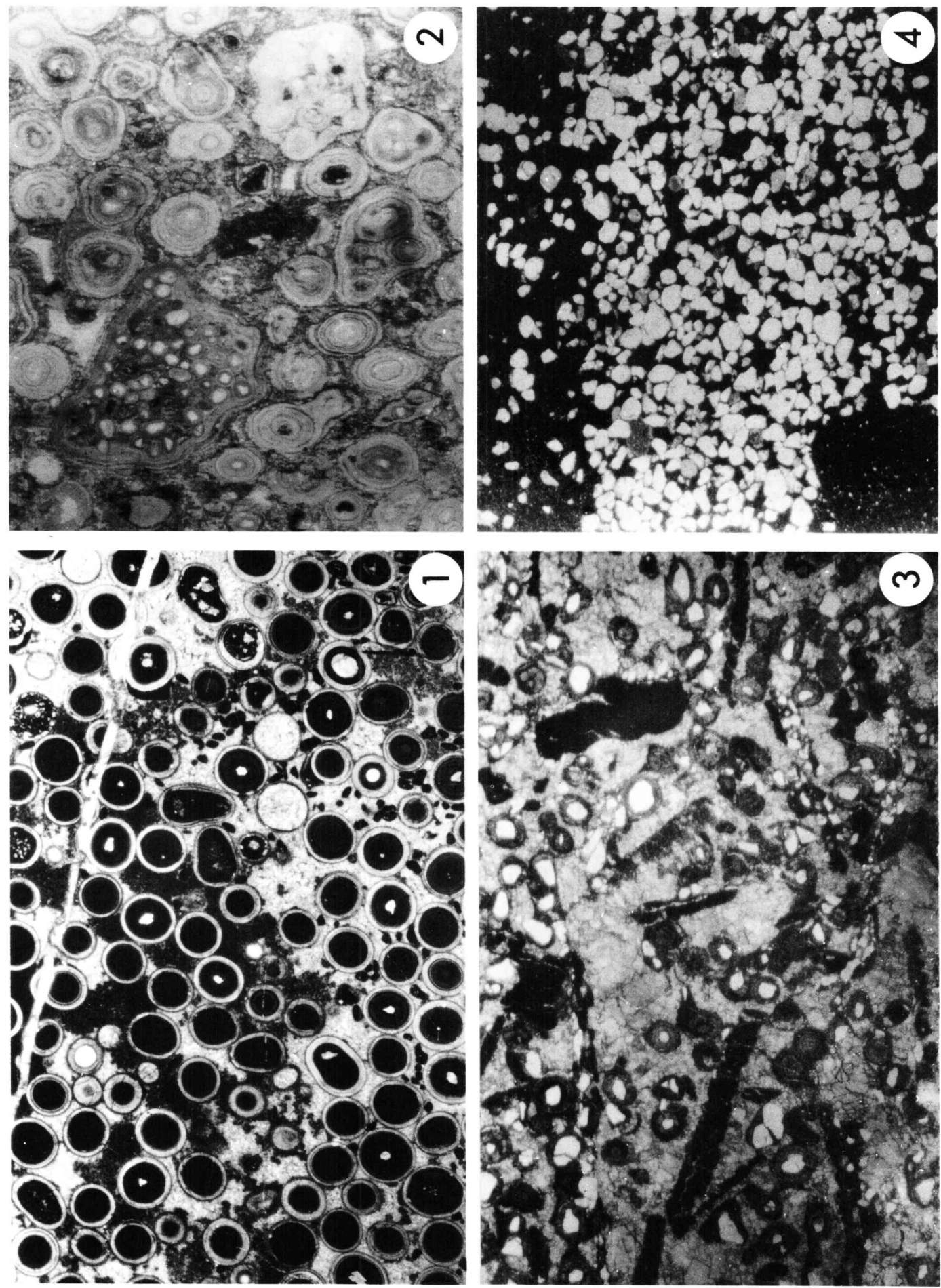

H. SAKAI: Kali Gandaki Supergroup 
bands and kink folds. Mylonitized dolomitic quartzites in the Kusum Khola suggest that this Klippe is composed of more than two thrust sheets. Internal structures of the klippe, especially of the lower thrust sheet is complicated. There are many overturned beds, tight folds, and faults, but detailed structures have not been verified yet.

\section{Khoraidi Fold Belt}

A highly complex fold-belt lies on the rear side of the Angha Khola Recumbent-Fold Belt and occupies the northernmost part of the outer belt (Fig. 3). The belt trends east-west for more than $35 \mathrm{~km}$ with a width of 2 to $5 \mathrm{~km}$. The northern and southern boundaries are separated by the Bari Gad Fault and Ramdi Fault, respectively. In this narrow belt are included the formations from the Heklang to the Ramdighat. In the northern half of this belt, these formations successively overlie and form a homoclinal structure. However in the southern half, they are isoclinally folded with parastic folds and cleavages, and the Khoraidi Formation is exposed four times with wave-length of 800 to $1000 \mathrm{~m}$ along the Khoraidi section (Fig. 4). It is important that the minor folds are Z-shaped and southerly verging (Pl. 47, Fig. 2) as in the minor folds of the Angha Khola Recumbent-Fold. Therefore, the Khoraidi Fold Belt is considered to form a part of the lower limb of the Angha Khola Recumbent-Fold. In the Waiga area, the whole sequence from the Virkot to Ramdighat Formation is overturned (Fig. 4). It means that the Khoraidi Fold-Belt is twisted toward. anticlockwise direction between the western and central parts.

\section{Inner Belt}

\section{Southern Block-Fault Belt}

The southern half of the inner belt is characterized by block faulting. The name "Midland" is derived from the depressed topography in the area between the Great Himalayas and Mahabharat Lekh, and it can be traced along the Kali Gandaki, Andhi Khola and Mradhi Khola in the study area (Fig. 4). This zone trends east-west with a width of $15 \mathrm{~km}$, and is separated by high-angle faults into five segments of a width of 1 to $5 \mathrm{~km}$. Gentle and open syncline in the central part and asymmetrical close-folds in the marginal part are the characteristic

\section{Explanation of Plate 49}

Fig. 1: Oolite of the Khoraidi Formation along the Angha Khola. Note that the concentric laminae show two stages of growth, inner dark laminae and outer light ones. $\times 9$

2: Oncolite of the Khoraidi Formation along the upper reaches of the Purba Khola. The maximum size attains $10 \mathrm{~mm}$ in diameter. Sampling site is shown in Fig. 10. $\times 10$

3: Arenaceous oosparite with some dolomitic micrite fragments, the Khoraidi Formation, the same locality as Fig. 2. Note rather thin ooid lamellae and angular-shaped quartz nuclei. $\times 10$

4: Wind-blown rounded to subrounded quartz grains in fine dolomicrite (originally limy mud) of the Upper Member of Chappani Formation on the river bank of the Angha Khola. $\times 7$ 
structures of each segment. Relative movement and vertical displacement along each fault are estimated on the base of stratigraphic levels of the rocks in each segment (Figs. 4 and 14). The vertical displacement along the Bari Gad Fault is more than $1000 \mathrm{~m}$, and that of the Keware Fault attains more than $1000 \mathrm{~m}$. These longitudinal faults extend to the west, Piuthan-Jajarkot area (ARITA et al., 1984) and cut both Jajarkot Crystalline Klippe and Sallyan Klippe (fig. 12 of ARITA et al., 1984). Therefore it is deduced that the block faulting have occurred after main stage of the activity of the MCT.

Small exposures of the Sisne Diamictite are left in the tributary areas of the Pindi and Mradhi Khola (Fig. 4). The formation is in fault contact with the Virkot Formation on the south, but the relations to other formations are uncertain.

\section{Northern Zone near the Phalebas Thrust}

The northern half of the inner belt in the area from Waling to Syangja (Fig. 2) is characterized by block faulting of NNE-SSW trend. This trend is parallel to the Thakkhola graben (HAGEN, 1969) in the Tibetan Tethys zone, 70 to $80 \mathrm{~km}$ north to Syangja. A gentle anticline with a NE-SW axial trace along the Andhi Khola is cut by NNE-SSW trending faults and E-W trending longitudinal faults, and resulted in a mosaic structure. Regarding this belt I studied only the narrow area along the Andhi Khola, so that I cannot give the structure of this belt. It should be noted, however, that the stratigraphy of the Middle and Upper Kali Gandaki Groups of the study area shows a normal order, while is reverse against to that of the Kusma-Sirkang area (UPRETI and MERH, 1978), to the west of Syangja. The Phalebas Thrust is cut by a normal fault of the NW-SE direction to the north of Syangja. It indicates that the block faulting has occurred after the main stage of thrusting of the Phalebas.

\section{Discussion}

\section{A. Geologic Age and Correlation}

1. Geologic Age

No palaeontological evidence for reliable age determination has been discovered from the large part of the Lesser Himalayan rocks except the Gondwana and post-Gondwana rocks (e.g. the Tansen Group) and the Tethys sediments (e.g. the Kathmandu Complex). The age of the Lesser Himalayan rocks has been disputed mainly on the basis of morphotypes of the stromatolites and radiometric dating. Regarding the geologic age of the lower part, KRUMMENACHER (1966) made K-Ar dating of rocks of the Kuncha Formation and reported 872 m.y. for the detrital muscovite of sandstone and $819 \pm 80$ m.y. for uralite from basic rocks.

There are two opinions about the age of the middle and upper parts. UPRETI et al. (1980) reported Collonnella and Conophytons from bluish-gray dolomitic stromatolite in the Kali Gandaki valley and regarded them as the Lower to Middle Riphean. VALDIYA (1980-c) also reported Jurusria and Kussiella from limestones and dolomites in the Trisuli valley in Central Nepal and 
Table 1. Regional correlation chart of Lesser Himalayan rocks among Kumaon, Western Nepal, Tansen-Syangja area, and Central Nepal.

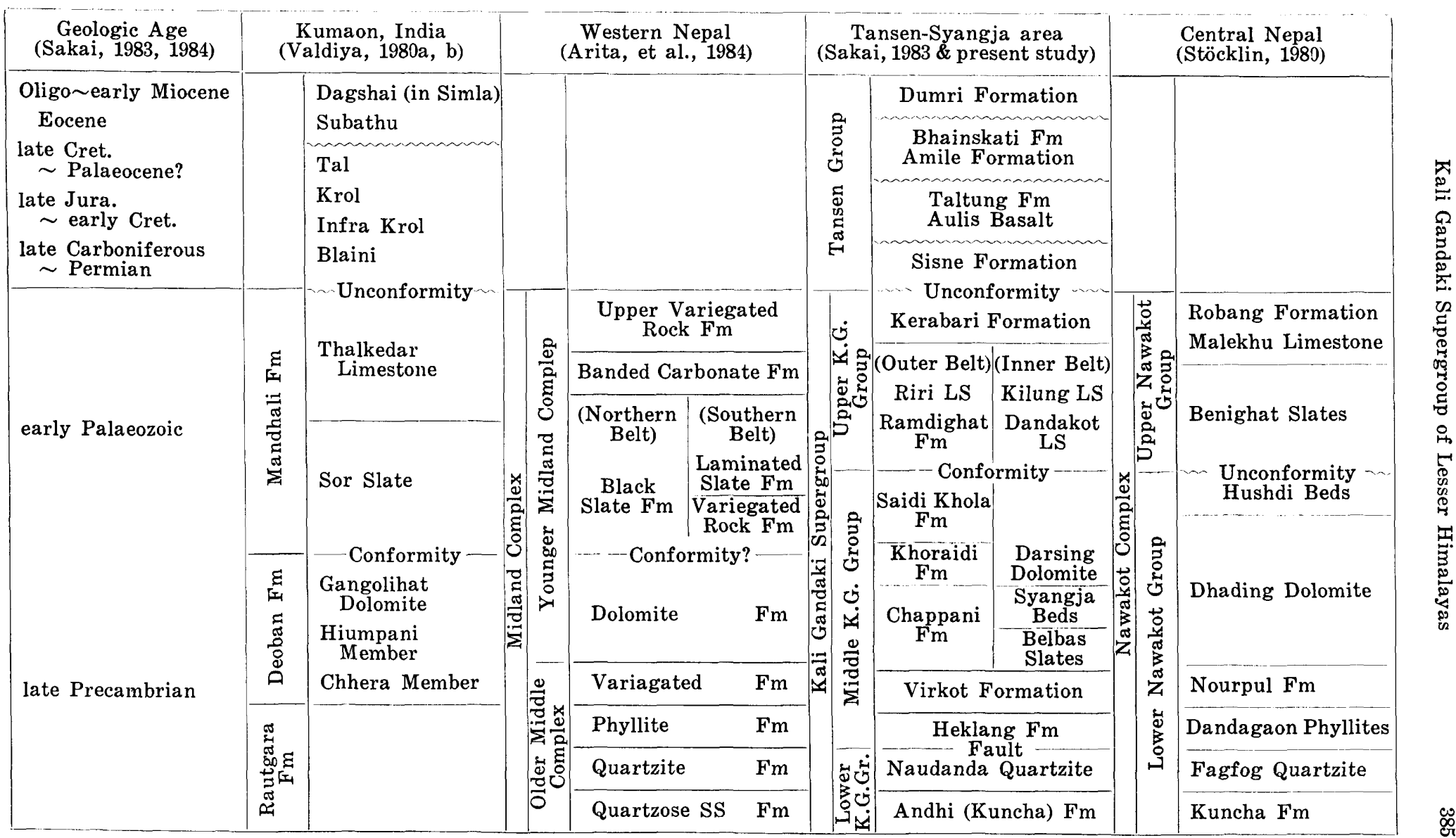


referred them to Riphean. On the other hand, STöckLIN (1980) discovered early Palaeozoic algae and echinoderm fragments from a boulder of the Dhading Dolomite in Central Nepal. This dolomite can be lithologically compared with the dolomitic stromatolite of Upreti (1980) in the Kali Gandaki valley. STöckLIN (1980) suggested a possibility that the Benighat Slates in Central Nepal is correlative with the Permo-Carboniferous Blaini-Infra Krol units of Kumaon. However, the Dhading Dolomite and the Benighat Slates are lithologically comparable with the Khoraidi and Ramdighat Formations respectively of the Middle and Upper Kali Gandaki Groups (Table 1). It is known that Colonnella- and Kussiella-type stromatolites occur from Proterozoic rocks.

A discovery of the Lower Cambrian stromatolite Ilicta Sidorov from the Deoban Limestone of Kumaon (SINHA and RAABEN, 1979), which has been regarded as Riphean in age on the basis of stromatolites (VALDIYA, 1969, 1980-a, and others), threw new light on the age of the Lesser Himalayan formations, although SINHA and RAABEN (1979) pointed out that "the taxonomic content of the Deoban stromatolitic assemblage has to be studied more thoroughly before a final conclusion is drawn about the upper and lower age limits." As the Deoban Limestone is correlated with the Khoraidi Formation (SAKAI, 1983, 1984), the age of the Khoraidi would be Cambrian.

The Vindhyan Supergroup in the northern Peninsula India has long been treated as a counterpart of the Lesser Himalayan rocks on the basis of the lithological similarities and occurrence of stromatolites (GANSSER, 1964; VALDIYA, 1969; BARMAN and Verma, 1976, and others), and regarded as Precambrian in age (CRAWFORD and COMPSTON, 1970; SALOP, 1977 and others). However, the discovery of Archaeocyathia, which is an important index fossil of the Cambrian, from the Rhotas Limestone (MAITHY and GUPTA, 1981) evidently indicates that the Upper Vindhyan and the top part of the Lower Vindhyan belong to the Cambrian. The recent discovery of Cambrian fossils suggests that the age of the Lesser Himalayan rocks range from late Precambrian to early Palaeozoic.

Regarding the age of the Kali Gandaki Supergroup most significant is the existence of carbonaceous beds at many horizons of the Upper Group (SAKAI, 1983). Carbonaceous and coaly beds with tiny plant remains from the Ramdighat and Kerabari Formations, Kilung Limestone (Fig. 5) and Benighat Slates suggests that the age of the Upper Group may range up to middle Palaeozoic. The Middle Group may possibly be Late Precambrian and Cambrian. Abundant occurrence of stromatolites, oolites, gypsum pseudomorphs and mud cracks show close affinities to the formations of those age in the Salt Range of Pakistan.

\section{Correlation and Stratigraphic Comparison}

It is unable to correlate the Kali Gandaki Supergroup with the Lesser Himalayan rocks of other areas, otherwise reliable fossils for age determination occur or well-defined lithostratigraphic sequences are established in every region and compared with one after another as shown by VALDIYA (1980-b). The stratigraphy of the Kali Gandaki Supergroup is comparable with those of Kumaon (VALDIYA, 1980-a) and Central Nepal (STöcKLIN, 1980) as already dis- 
cussed (SAKAI, 1983, 1984). In this connection, lithofacies changes between the inner and outer belt must be taken into consideration. The red and green coloured rocks found in the Ramdighat Formation are absent in the corresponding beds of the northern Syangja area (Fig. 5, Table 1) and the Benighat Slates in Central Nepal. The Benighat Slates is three times as thick as the Ramdighat Formation. On the contrary, the overlying Malekhu Limestone is only half the thickness of the Kerabari Formation.

Lithologies of the Vindhyans are very similar to those of the Kali Gandaki Supergroup; the presence of quartzites with sun cracks and current ripple bedding structures and stromatolitic carbonate rocks are common to both supergroups. They are considered to have been deposited in fluvial environments under semi-arid conditions (AUDEN, 1933; SAKaI, 1983, present study). The thickness of the Vindhyans in the classical field of the Son Valley, $300 \mathrm{~km}$ south of the Kali Gandaki area is about $1500 \mathrm{~m}$ (AUdEN, 1933). The maximum exposed thickness attains $6500 \mathrm{~m}$ (KARUNAKARAN and RANGA RAO, 1976). According to the deep drilling results at several points in the Gangetic Plains (KARUNAKARAN and RANGA RAO, 1976), the Vindhyans is thin or missing there (Fig. 18).

On the contrary, the Lesser Himalayan rocks have a surprisingly great thickness, which is several times the thickness of the Vindhyans in the Peninsular India. This is common to the whole Lesser Himalayas. The Kali Gandaki Supergroup of the study area and Nawakot Complex (STöckliN, 1980) in Nepal exceed $10,000 \mathrm{~m}$. In the Kumaon area, the thickness of the Lesser Himalayan rocks, excluding the sequence from the Blaini to Subathu Formations, attains 13,000 m (VALDIYA, 1980-a). In the Simla area, omitting the Krol belt, it attains $7000 \mathrm{~m}$ (SINHA, 1980). In every area, the total thickness of the Lesser Himalayan sediments far exceeds $10,000 \mathrm{~m}$, if the rocks of the Krol belt is included.

As noted above, the thickness of the Lesser Himalayan rocks coeval to the Vindhyan Supergroup and Gondwana rocks in the Peninsular India and Gangetic Plains abruptly increases in crossing the MBT (Fig. 18). This is especially outstanding between the Simla and Adampur where the Vindhyans and Gondwanas are missing and the Siwaliks directly rest on the basement (KARUNAKARAN and RANGAO RAO, 1976). This great difference of the thickness between the rocks of the same ages in the Lesser Himalayas and Gangetic Plains and Peninsular India has been attributed to the difference of original basin configurations or to the difference of denudation (KARUNAKARAN and RANGAO RAO, 1976). However, it is difficult to explain this abrupt and great change of thickness by only these factors. If we would suppose intracontinental subduction along the MBT, this change will be fully explained by that the formations, which are at present adjoining each other along the MBT, were once situated in far off places, and that after intracontinental subduction took place along the MBT, the formations of disparate thickness were juxtaposed to each other. I think that horizontal displacement along the MBT should not be ignored, although the net slip by subduction cannot be reckoned. 


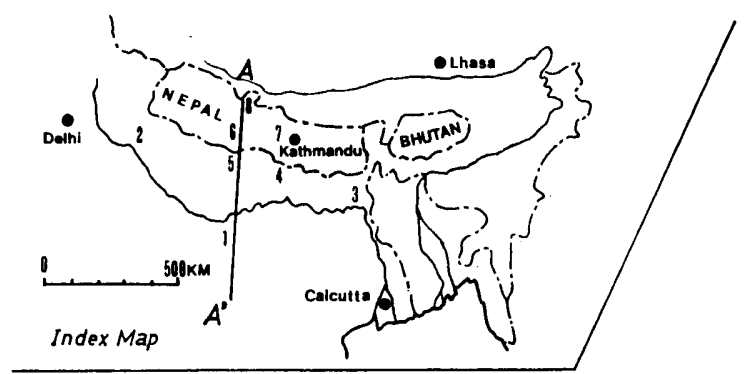

Bh: Bhainskati Fm.(Eocene)

$\checkmark$ : Vindhyan

$\because \because \mathrm{Si}$ : Siwaliks

UG : Upper Gondwanas

LG : Lower Gondwanas

IIIII Uv : Upper Vindhyan

LV: Lower Vindhyan

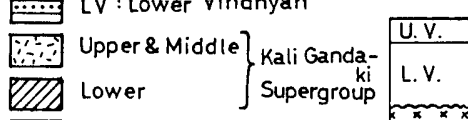

Precambrian Basement

$$
\begin{aligned}
& \text { 1. Son Valley } \\
& \text { (Auden, 1933) }
\end{aligned}
$$

Indian Shield

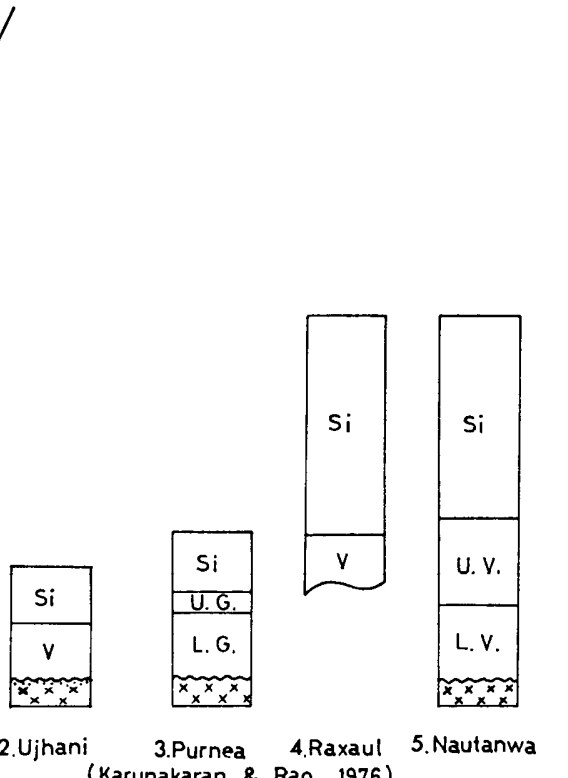

(Karunakaran \& Rao, 1976)
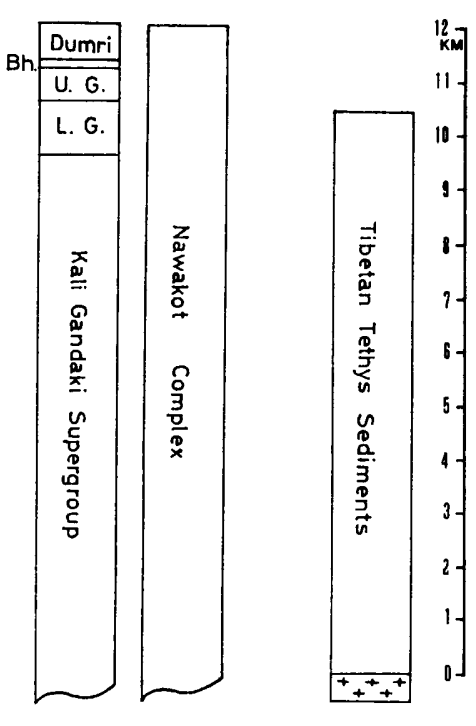

6. Tansen 7.Kathmandu 8.Thakkola (Sakai, 1983.1984)(Stöcklin, 1980) (Bordet et al., +Lesser

$A^{\prime}$

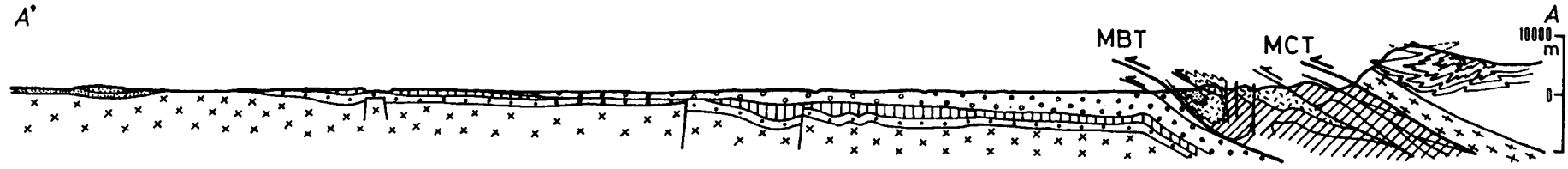

\section{0 $100 \mathrm{KM}$}

Fig. 18. General cross-section of northern margin of Indian shield, Gangetic Plain and Himalayan Range, and stratigraphic sections at representative areas. The profile of the Indian Shield and Gangetic Plain is after KARUNAKARAN and RANGA RAO (1976), that of the Great Himalayas after BoRDET et al. (1971) and that of the Lesser Himalaya after ARITA et al. (1982) and SAKAI (1983). 


\section{B. Sedimentary Environment and Depositional History}

The Kali Gandaki Supergroup is marked by laterally consistent and vertically closely related sedimentary facies that was common in peritidal environments. There are three main quartzite beds, namely in the Naudanda, Virkot and Chappani in ascending order. Those of the Naudanda are characterized by white, remarkably rippled, flat-bedded quartzites and are accompanied with some amphibolite; the Virkot Quartzite is pink, cross-bedded and rippled ones with intercalation of reddish-purple and green shale-pebble conglomerate; the Chappani is characterized by white, pink and green quartzite. These quartzite beds are considered to have accumulated as coastal and dune sands under arid climate conditions.

Stromatolites are recognized in the Chappani, Khoraidi and Kerabari Formations. Those of the Chappani are small, columnar in shape. They are composed of limestone, but are silicified at several horizons. The Khoraidi Formation is predominantly made up of dolomitic stromatolites of various types and of large sizes. The Kerabari also contains many, thin sheet-formed stromatolites with smooth and pustular surfaces. These stromatolite beds evidently show deposition in intertidal to very shallow subtidal zones.

About a half of the sequence of the Kali Gandaki Supergroup, that is the most part of the Andhi, the Heklang, the Middle and Lower Members of the Chappani, and the Ramdighat Formation, is represented by slate or shale. They are finely laminated in parallel and monotonously similar in lithology. These features indicate deposition in a calm, closed basins like a lagoon, epeiric bay and lake.

Rhythmite and coarsely interlayered fine-grained sandstone and shale of the Saidi Khola Formation and at several intervals of the Khoraidi Formation are intensely bioturbated with burrows and are interpreted as sandy intertidalflat deposits.

Reddish-purple argillaceous beds are remarkable in the Virkot and Ramdighat Formations. Those of the Virkot are frequently sun-cracked and are interlayered with rippled and cross-bedded quartzose sandstone. They are interpreted to have been deposited in sabkha with intermittent supply of coarser sediments by fluvial and aeolian influences. They are more or less dolomitic and are not easily dissolved by hydrochloric acid. On the other hand those of the Ramdighat exhibit only fine parallel lamination, and are calcitic, being easily dissolved by hydrochloric acid. Thus these two formations can be distinguished from each other. To sum up, it is concluded from lithologic assemblages and sedimentary features that the Kali Gandaki Supergroup was deposited under arid climate conditions in peritidal environments laterally associated with a very shallow subtidal to intertidal zone in front and lagoonal to supratidal sabkha zones on the rear side as shown in Fig. 13. The water depth is supposed to have been within about $10 \mathrm{~m}$ above and below the sea level. The sequence of a lithologic assemblage consisting of stromatolites, dolomite, rhythmite, redpurplish shale and quartzose sandstone and repeated appearance of these rocks reflect fluctuation of a shoreline due to slight changes of the sea level. The great thickness of the sequence without erosional interruption throughout the super- 
group suggests a continuous but slow subsidence of the sedimentary basin. An unconformity is known at the boundary between the Upper and Lower Nawakot Groups in Central Nepal (STöckLIN, 1980). This boundary corresponds to that between the Upper and Middle Kali Gandaki Groups in the Tansen area, but no unconformity is recognized between them. ARITA et al. (1984) also reported a gradual change between their Older and Younger Midland Complex that correspond to the Middle and Upper Kali Gandaki Groups, respectively. Therefore the unconformity between the Nawakot Groups seems to be local.

Three main quartzose sandstones and four main argillites indicate relative upheaval and subsidence of the sedimentary basin, respectively. The upward increase of this thin sandy beds and reddish-purple dolomites in the Kerabari Formation may possibly reflect general upheaval of the sedimentary basin.

The main palaeocurrent system of the Kali Gandaki Supergroup shows consistent directions from $\mathbf{E}$ to $\mathrm{W}$ and from $\mathrm{S}$ to $\mathrm{N}$. These facts mean that the supergroup was deposited on stable continent where no orogenic movements have occurred.

\section{Synthesis of Geologic Structure}

There are two opinions about the structural scheme and tectonic movement of the Lesser Himalayas in Nepal; one sets importance on the nappe tectonics with great lateral displacement (HAGEN, 1969), and the other places emphasis on block movement by longitudinal faults with vertical displacement (HASHIмото et al., 1973). The former regards the Lesser Himalayas as a great stack of nappes, each of which being bounded by a thrust; while the latter did not recognize nappe structures in Central and Western Nepal except Eastern Nepal and considered that the schuppen and nappe structures are subsidiary to the tectonics of the Himalayan Range. Stöcklin and BHATtaRaI (1977) and STöckLIN (1980) studied the Central Mahabharat Range in detail and revealed that only the Kathmandu Nappe overthrusts on the Nawakot Complex of the Lesser Himalayan autochthonous sediments. Furthermore they disclosed that the Mahabharat Thrust is the southward continuation of the Main Central Thrust, and that the Kathmandu Complex forms a large syncline. They also reported the existence of vertical transverse faults.

Tansen-Syangja area can be structurally divided into two belts; one is the outer thrust-and-fold belt which forms the Mahabharat Lekh, and the other is the inner longitudinal block-fault belt which forms southern half of the Midland, as mentioned before. The outer belt is characterized by a schuppen structure, a synclinorium with a tectonically overlying klippe and a recumbent fold belt from south to north. These belts form topographically uplifted Mahabharat Lekh just behind the MBT. On the contrary, the southern half of the inner belt is characterized by longitudinal faults with large vertical displacements and broad open-folds. These structures form topographically depressed Midland on the rear side of the outer topographically high. Thus, the outer belt is marked by compressional structures and the inner by tensional structures. These two belts are separated by the Beri Gad Fault which has a component of right-lateral displacement. The juxtaposition of the belts of the compressional and tensional 
structures can be explained by that the compressional stress field was generated along the frontal margin of advancing thrust sheets and tension stress field was subsequently distributed on the rear side of compressional stress field. Right lateral displacement occurred along the boundary fault between the compression and tension stress fields. The occurrence of the subsequent tension stress on the rear side of the compression stress field is not uncommon in large thrust-sheet belts like the Canadian Rocky (PRICE and MounTJOY, 1970; ElliotT, 1976). It is certain that a tension stress occurs together with a compression stress in an inclined compression stress field. Therefore the structural and topographic differences between the Mahabharat and the Midland can be attributed to partial variations of stress field in a major thrust sheet (Fig. 19).

This idea seems to be applicable to the structure of the Great Himayalas. The Great Himalayas is also divided into two belts from the topographic view; the Great Himalayan Range which comprises the southern flank and summits of the Himalayan giants exceeding $8000 \mathrm{~m}$ in altitude, and the northern Tibetan Marginal Range (HAGEN, 1969). The former is characterized by complicated recumbent folds and imbricated structures, and its front is separated by the MCT from the Lesser Himalayas (BORDET et al., 1971, 1972). The latter forms a broad synclinorium with gentle downwarping and broad open folds, and is transected by faults into a number of differentially elevated or depressed blocks (HAGEN, 1969; BORDET et al., 1971; STöckLIN, 1980). This juxtaposition of the two different topographies and structures can be probably explained by partial differences of stress field in a large thrust sheet of the Central Crystalline and Tibetan Tethys sediments (Fig. 19).

\begin{tabular}{|c|c|c|c|c|}
\hline $\begin{array}{l}\text { Intracontinental } \\
\text { Subduction }\end{array}$ & $\left|\begin{array}{c}\text { Recumbent } \\
\text { fold } \\
\begin{array}{c}\text { schuppen } \\
\text { structure }\end{array}\end{array}\right|$ & $\begin{array}{l}\text { Broad open fold } \\
\text { Block tault }\end{array}$ & $\begin{array}{l}\text { Recumbent fold } \\
\text { Schuppen } \\
\text { structure }\end{array}$ & $\begin{array}{l}\text { Broad open fold } \\
\text { Gentle warping } \\
\text { Block fault }\end{array}$ \\
\hline & Tectonite & & mylonite Granite & te Intrusion \\
\hline $\begin{array}{c}\text { Gangetic } \\
\text { Plain }\end{array}$ & Lesser & Himalayas & $\begin{array}{c}\text { Great } \\
\text { Himalayas }\end{array}$ & Tibet \\
\hline
\end{tabular}
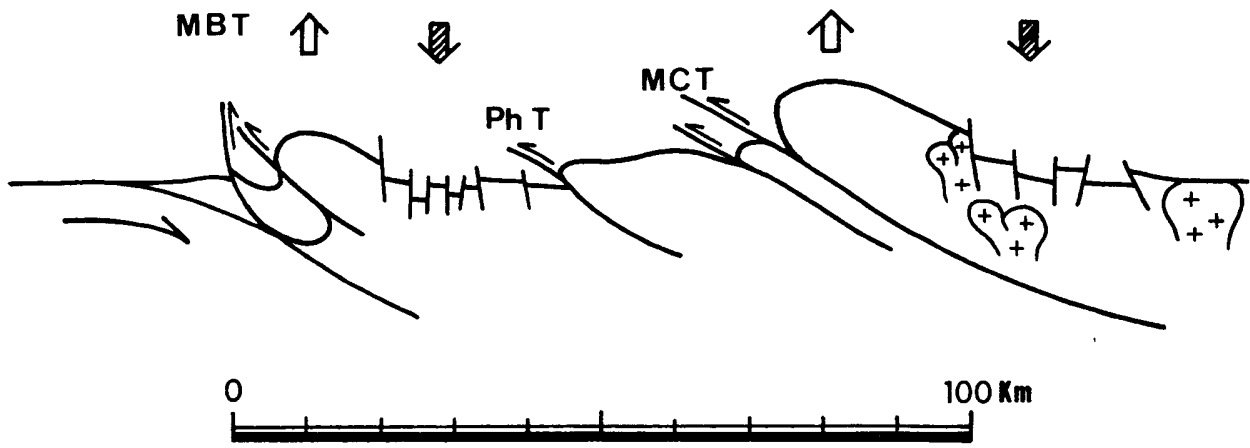

Fig. 19. Simplified model to explain principal major structures of Himalayan Range in western Central Nepal. 


\section{Tectonic History}

1. Pre-Gondwana Time (Precambrian to early Palaeozoic)

No evidence of significant orogenic movements is recorded in the Kali Gandaki Supergroup. Neither any stratigraphic breaks nor any remarkable changes of lithologic assemblages which must have reflected the changes of sedimentary environments are recognized throughout the whole sequence in spite of its great thickness. The sedimentary facies of each formation is laterally very consistent over wide areas. These facts mean that the supergroup was deposited in a vast basin on a stable basement which continuously subsided for a long time. The sediments of the Kali Gandaki Supergroup are inferred to have been deposited in peritidal environments ranging from very shallow marine ones to sabkha under arid climate conditions.

\section{Gondwana Time (late Palaeozoic to late Mesozoic)}

Two distinct unconformities at the base of the lower and the upper Gondwanas record major tectonic movements on the Gondwana continent (SAKAI, 1983, 1984). The basaltic volcanic activity represented by the Aulis Basalt of the Taltung Formation in the Lesser Himalayas (SAKAI, 1983) and the deposition of the coeval lower Cretaceous basaltic pebble-conglomerate and sandstone in the Tibetan Tethys (BORDET, 1961; BORDET et al., 1971) must have been related to each other. This basic igneous activity seems to have accompanied the rifting of the Gondwana continent during late Jurassic and early Cretaceous times. The continental sandstone at the base of the marine Cretaceous of the Tibetan Tethys (BORDET et al., 1971) and the quartzite pebble-conglomerates at the base of the Taltung Formation in the Lesser Himalayas (SAKAI, 1983) must indicate a preceding warping of the Gondwana continent and erosion of exposed basement rocks before the eruption of basaltic lavas.

\section{Post-Gondwana Time (Tertiary to Recent)}

The first occurrence of mammal fossils in the Indian subcontinent was reported from the Middle Eocene Formation (Shani and Kumar, 1974; Shani, 1976). In addition, a discovery of land-mammal fossils and Middle Eocene foraminifers from the Bhainskati Formation in the Tansen area (SAKAI, 1983) provides further eviednce for this inference. KHANNA and SINGH (1979) pointed out that the depositional environment of the Subathu Formation varied from shallow marine below to brakish water, probably even to fresh water conditions above on the basis of palynological study. These facts suggest that the collision of Indian Subcontinent against the Eurasia has started at Middle Eocene (45 m.y. B.P.).

Then when did the tectonic movement start and how have major structures of the Himalayan Range in Nepal been developed? Tectonic movements must have been recorded as stratigraphic breaks or rapid lithofacies changes or changes of sediment components. The first important event is reflected in the disconformity with a distinct erosion surface between the fluvial, thick, coarse sandstone of the Dumri Formation and the underlying marine Bhainskati Formation of Eocene age (SAKAI, 1983, 1984). The Dumri sand- 
stone somewhat abundantly contains, besides detrital quartz, clasts of phyllitic slate which must have been derived from the Himalayan terrane. This indicates the initiation of upheaval of the terranes on the north of the Lesser Himalayan Range. As already noted (SAKAI, 1984), the Dumri Formation can be correlated with the Dagshai Formation in the Simla Himalayas and the Lower Murrees of the Sub-Himalayan Range. These are all characterized by a thick sequence of massive sandstone which show rapid sedimentation. These beds are nothing but the reflection of the continuous uplift of the northern Himalayan range and of the enormous sediment supply into the frontal basin in the Lesser and SubHimalayan terranes.

The tectonic activity along the MCT and the large-scale denudation of the frontal part of the High Himalayan Range are marked by the appearance of the Himalayan Gneiss on the ground surface and the supply of the materials eroded from the gneisses into the Siwaliks. According to the petrographic study of Siwalik sandstone in Garhwal Himalayas (PRASAD and Verma, 1976), rockfragments of geneiss and schist first appear in the Upper Siwalik. The Middle Siwalik is characterized by abundant muscovite-biotite occurrence and bad sorting (Hagen, 1969; Prasad and Verma, 1976; Tokuoka and Yoshida, 1984). As the sandstone of the Lower Siwalik is mainly composed of detrital quartz and phyllitic slate rock-fragments as in the Dumri Formation, the appearance of the Himalayan Gneiss to the ground surface is considered to have occurred during the Middle Siwalik time. The ages of basal beds of the Middle and Lower Siwaliks are estimated about 11 m.y. and 13.1 m.y. on the base of geomagnetic study in the Potwar Plateau (JoHnson et al., 1982). Therefore, it is certain that the Himalayan Gneiss was exposed to the ground surface around 11 m.y. B.P. at the latest. The Himalayan Gneiss is overlain by a thick pile of the Tibetan Tethys sediments more than $10 \mathrm{~km}$ in thickness. This means that the vertical displacement of more than $10 \mathrm{~km}$ occurred along the frontal part of the MCT.

STöcKLIN (1980) clarified that the Kathmandu Nappe, which is intruded by Oligocene to Miocene granite lies upon the autochtonous Nawakot Complex along the Mahabharat Thrust, the southward continuation of the MCT. As the youngest age of the granite is dated as 16 m.y. (VIDAL, in CNRS, 1977, p. 539), the overthrusting of the MCT commenced after 16 m.y. B.P.

FRANK and FUCHS (1970) showed that the main thrusting took place after the deposition of the Lower Miocene Dagshai Formation, because the formation is tectonically covered by the Chail Nappe. This interpretation is also supported by that the Dumri Formation of probable Oligocene to Lower Miocene ages is overlain by the Palpa Klippe in the Tansen area (SAKAI, 1983; Fig. 14-A).

These data indicate that the orogenic epoch accompanied by rapid upheaval and intense structural deformation started after Middle Miocene. Le ForT (1975) clarified that the resumption of movements of the Indian Plate at 9 to 10 m.y. B.P. corresponds to the initiation of underthrusting along the MBT. This plate movement is recorded by volcanic tuffs in the Nagri Formation of the Middle Siwaliks in the Potwar Plateau (JoHNson et al., 1982). I think 
that the plate movement at this time caused overthrusting of the Lesser Himalayan belt along the MCT and that the southward advancement of the Lesser Himalayan Crystalline nappe gave rise to the subordinate generation of the MBT.

ARITA et al. (1984) showed that the Jajarkot Crystalline klippe and Sallyan klippe are truncated by longitudinal vertical faults in the Piuthan-Jajarkot area just west of the Tansen area. Furthermore, they also indicated that the development of longitudinal valleys on the rear side of the Mahabharat Lekh all over the Nepal implies the rapid elevation of the Mahabharta Lekh in Recent time. In summary, the uplift of the Mahabharat Lekh and the longitudinal block faulting in the southern part of the inner belt are considered to have occurred after overthrusting of the Lesser Himalayan Crystalline Nappe, that is the underthrusting of the Indian Continent along the MCT.

It is certain that the present structures and tectonic history of the outer belt of the Lesser Himalayas are formed by superimposition of the MBT activity on the MCT one. To distinguish the structures formed by the activity of the MCT from that by the MBT is difficult at present. This problem will be solved by detailed structural analysis of the Lesser Himalayan rocks subjacent to the Crystalline rocks in the Jajarkot-Piuthan and Kathmandu areas and by comparative structural studies among the Jakarkot-Piuthan, Tansen and Kathmandu areas. On the other hand, the structural analysis of the Siwaliks will play an important role to solve the tectonic history of the MCT and MBT.

One of the purposes of the present study was to show a significance of establishment of stratigraphy based on detailed regional mapping and careful observation, for the students of Department of Geology, Tribhuvan University. The geological maps and descriptions of SAKAI (1983) and the present paper are not complete and have many problems in spite of my efforts for three years in Nepal. I hope that my research results will be revised by Nepalese geologists who are graduated from the Department of Geology, Tribhuvan University.

\section{Acknowledgements}

I would like to again express my sincere thanks to all persons and organizations noted in the first paper of this series. Especially, with respect to this paper I am much indebted to the following persons: Dr. M. P. Sharma, Dr. B. N. Upreti and Mr. B. M. Pradhan of the Department of Geology, Tribhuvan University and Mr. J. M. Tater, Dr. Y. L. Singh, Mr. S. B. Shrestha and T. P. Adhikari, the Department of Mines and Geology, H. M. G. Nepal.

\section{References}

Alderman, A. R. and Von der Borch, C. C. (1960): Occurrence of hydromagnesite in sediments in South Australia. Nature, 188, 931.

Arita, K., Hayashi, D. and Yoshida, M. (1982): Geology and structures of the Pokhara-Piuthan area, central Nepal. Jour. Nepal. Geol. Soc., 2, Special Issue, 5-29. 
ARItA, K. and YoshidA, M. (1982): Geological observations along motor road from Butwal to Ramdighat, central Nepal. Ibid., 51-58.

, Sharma, T. and FUJII, Y. (1984): Geology and structure of the JajarkotPiuthan area, central Nepal. Ibid., 4, Special Issue, 5-28.

Auden, J. B. (1933): Vindhyan sedimentation in the Son Valley, Mizarpur district. Mem. geol. Surv. India, 62, 2, 141-250.

(1934): The geology of the Krol Belt. Rec. geol. Surv. India, 67, 4, 357-454.

Barman, G. and Verma, K. K. (1976): A comparative study of the stromatolites from the Carbonate Formations of the Himalayan Region and the Vindhyans. Geol. Sur. India. Miscellaneous Publ. No. 41, (II), 181-188.

BoRdet, P. (1961): Recherches geologiques dans l'Himalaya du Nepal, region du Makalu (CNRS ed.), Paris, 275p.

- Colchen, M., Krummenacher, D., Le Fort, P., Mounterde, R. and Rem Y, J. M. (1971): Recherches geologiques dans l'Himalaya du Nepal, region de la Thakkola (CNRS ed.), Paris, 279 p.

- Colchen, M. and Le ForT, P. (1972): Some features of the Geology of the Annapurna Range, Nepal Himalaya. Himalayan Geology, 2, 537-563.

Clifton, H. E. (1980): Estuarine Deposits. In: Scholle, P. A. and Spearing, D., (eds.), Sandstone Depositional Environments. Am. Assoc. Petr. Geol., 179-189.

CNRS. (1977) : Discussions. In: Himalaya, Colloque internat. 268, CNRS ed., Paris, $540 \mathrm{p}$.

Crawford, A. R. and Compston, W. (1970): The age of the Vindhyan System of Peninsular India. Jour. Geol. Soc. London. 125, (35), 1-371.

ElliotT, D. (1976): The motion of thrust sheets. Jour. Geophys. Res., 81, (5), 949963.

FolK, R. L. (1968): Bimodal supermature sandstones: product of the desert floor. Internat. Geol. Congress, 23rd, Prague., sec. 8, 9-32.

Frank, W. and Fuchs, G. R. (1970): Geological investigations in west Nepal and their significance for the geology of the Himalayas. Geol. Rdsch., 59, 552-580.

Fuchs, G. (1980): The Lesser Himalayan Geology of west Nepal and its regional importance. In: VALdIYA, K. S. and BhATIA, S. B. (eds.), Stratigraphy and Correlations of the Lesser Himalayan Formations. Hindustan Publ., Delhi, 163-173.

—_ and Frank, W. (1970): The Geology of west Nepal between the rivers Kali Gandaki and Thulo Bheri. Jahrb. Geol. Bundesanst., 18, 103 p.

Gadow, S. (1970): Sedimente and Chemismus. In: Reineck, H. E. (ed.), Das Watt, Ablagerungs und Lebensraum, 23-35.

GaNsSER, R. (1964) : Geology of the Himalayas. John Wiley \& Sons, London, $289 \mathrm{p}$.

HAGEN, T. (1969): Report on the geological survey of Nepal, 1, Preliminary reconnaisance. Denkschr. Schweiz. naturf. Ges., 86, $159 \mathrm{pp}$. (1980) : Nepal. Oxford \& IBH Publ., New Delhi, 264 pp.

Hardie, L. A. (ed.). (1977): Sedimentation on the Modern Carbonate Tidal Flats of Northwest Andros Island, Bahamas, Johns Hopkins Univ. Press, Baltimore, $202 \mathrm{p}$.

Hashimoto, S., Онта, Y. and Akiba, Ch. (eds.), (1973): Geology of the Nepal Himalayas. Saikon Publ., Sapporo, 292 p.

HEDBERG, H. D. (ed.), (1976): International Stratigraphic Guide-a guide to stratigraphic classification, terminology, and procedure. New York, Interscience Publ., 200 p.

HoffmaN, P. (1976) : Stromatolite mophogenesis in Shark Bay, Western Australia. In: WAlter, M. R. (ed.), Stromatolites, 261-271, Elsevier, Amsterdam.

Illing, L. V., Wells, A. V. and TAYLOR, J. C. M. (1965) : Penecontemporaneous dolomite in the Persian Gulf. In: Pray, L. C. Murray, R. C. (eds.), Dolomitization and limestone diagenesis: a symposium. Spec. Publ. Soc. econ. Paleont. Miner., 13, 89-111. 
Johnson, N. M., Opdyke, N. D., Johnson, G. D., Lindsay, E. H. and Thairkheli, R. A. K. (1982): Magnetic Polality Stratigraphy and Ages of Siwalik Group Rocks of the Potwar Plateau, Pakistan. Palaeogeogr., Palaeoclimatol., Palaeoecol., $37,17-42$.

KaRunakaran, C. and RANGA, RAO A. (1976): Status of Exploration for hydrocarbon in the Himalayan Region-Contributions to stratigraphy and structure. Geol. Sur. India. Miscellaneous Publ. 41, (V), 1-66.

KhannA, A. K. and Singh, H. P. (1979): Palynological evidences in determination of algae and environment of deposition of the Subathu Formation, Simla hills. Himalayan Geology, 9, (I), 292-303.

KRUMmenacher, D. (1966): Nepal Central: geochronmetrie des series de l'Himalaya. Schweiz. Min. Petro. Mitt., 46, 43-54.

Le ForT, P. (1975): Himalayas: the collided range. Present knowledge of the continental arc. Am. Jour. Sci., 275, 1-44.

MaIthy, P. K. and GUPTA, S. (1981): Archaeocyatha from the Vindhyan Supergroup, India. Ind. Jour. Earth Sci., 8, (1), 76-81.

MASCLE, G. H. (1980) : Tectonic reconstruction of stratigraphy of Midland in Central Nepal in the light of structural analysis. In: VAldiYA, K. S. and BhATIA, S. B. (eds.), Stratigraphy and Correlations of Lesser Himalayan Formations. Hindustan Publ. Delhi, 191-197.

Nakata, T. (1982): A photogrametric study on active faults in the Nepal Himalayas. Jour. Nepal. Geol. Soc., 2, Special Issue, 67-80.

-, Iwata, S., Yamanaka, H., Yagi, H. and Maemoku, H. (1984): Tectonic landforms of several active faults in the western Nepal. Ibid., 4, Special Issue, $177-199$.

Ohta, Y., Akiba, C., Arita, K. and Maruo, Y. (1973): Regional Geology of PokharaGurkha Region. In: HASHImoto, S., ОнтА, Y. and AKIBA, C. (eds.), Geology of the Nepal Himalayas. 159-188.

Prasad, C. and Verma, V. K. (1976): Study of Siwalik and Post Siwalik sandstone types and their depositional conditions in Western Dun Valley, Garhwall Himalaya. Geol. Surv. India, Miscellaneous Publ., 41, (II), 126-132.

Preiss, W. V. (1976): Basic field and laboratory methods for the study of stromatolites. In: WALter, M. R. (ed.), Stromatolites. Elsevier, Amsterdam, 5-13.

Price, R. A. and MountJoy, E. W. (1970): Geologic structure of the Canadian Rocky Mountains between Bow and Athabasca Rivers - Progress report. Geol. Assoc. Can. Spec. Paper, 6, 7-25.

Purser, B. H., (ed.), (1973): The Persian Gulf: Holocene Carbonate Sedimentation and Diagenesis in a Shallow Epicontinental Sea. Springer Verlag. Berlin. 471 p.

REINECK, H. E. (1967) : Layered sediments of tidal flats, beaches and shelf bottoms of the North Sea. In: Lauff, G. H. (ed.), Estuaries. Am. Assoc. Advanc. Sci. Publ., 83, 191-206.

, and Singh, I. H. (1980): Depositional Sedimentary Environments. Springer Verlag, Berlin, $549 \mathrm{p}$.

REMY, J. M. (1975) : An introduction to the geology of the western Nepal. Himalayan Geology, 5, 280-301.

SAHNI, A. (1976): The timing of fragmentation and collision of the Indian Plate: Its bearing on Himalayan Geology. Geol. Soc. India. Miscellaneous Publ., 41, (IV), 235-242.

and Kumar, V. (1974): Palaeogene Palaeobiogeography of the Indian subcontinent. Palaeogeogr. Palaeoclimatol. Palaeoecol., 65, 209-226.

SAKAI, H. (1983): Geology of the Tansen Group of the Lesser Himalaya in Nepal. Mem. Fac. Sci., Kyushu Univ. Ser. D., [Geol.], 25, (1), $27-74$.

(1984): Stratigraphy of Tansen area in the Nepal Lesser Lesser Himalayas. Jour. Nepal. Geol. Soc., 4, Special Issue, 41-52.

SAKo, S., ISHIDA, T. and OHTA, Y. (1973): Regional geology of Dhaulagiri region. 
In: Hashimoto, S., OHtA, Y. and AkIBA, C. (eds.), Geology of the Nepal Himalayas. 189-217.

Salop, L. J. (1977): Precambrian of the northern hemisphere. Elsevier, Amsterdam, $378 \mathrm{p}$.

Sharma, C. K. (1977) : Geology of Nepal. Education Enterprises, Kathmandu, 164 p. (1980): Stratigraphy of Lesser Himalayan formations of western and far western Nepal. In: VAldiYA, K. S. and BHATIA., S. B. (eds.), Stratigraphy and Correlation of Lesser Himalayan Formations. Hindustan Publ., Delhi, 174-179.

Shinn, E. A. (1983) : Tidal flat environment. In: Scholle, A., et al., (eds.), Carbonate Depositional Environments. Am. Assoc. Petro. Geol. Mem., 33, 171-210. , Ginsburg, R. N. and LloYD, R. M. (1965) : Recent supratidal dolomite from Andros Island, Bahamas. In: PraY, L. C. and Murray, R. C. (eds.), Dolomiti zation and Limestone Diagenesis: a symposium. Spec. Publ. Soc. econ. Paleont. Miner., 13, 112-123.

SingH, P. (1973): A note on the fossiliferous Formation in Lesser Himalaya of Nepal and Bhutan. Himalayan Geology, 3, 372-380.

SinHA, A. K. (1980): Tectono-stratigraphic problem in the Lesser Himalayan zone of Simla region, Himachal Pradesh. In: VAldiYA, K. S. and BhAtiA, S. B. (eds.), Stratigraphy and Correlations of Lesser Himalayan Formations. Hindustan Publ., Delhi, 99-116.

SinhA, A. K. and RAABEN, M. E. (1979): Lower Cambrian stromatolite from the Deoban Limestone of Lesser Himalaya. Himalayan Geology, 9, (I), 316-323.

StöckliN, J. (1980): Geology of Nepal and its Regional Frame. Jour. Geol. Soc. London, 137, 1-34.

and BhattaraI, K. (1977) : Geology of Kathmandu area and Central Mahabharat Range, Nepal Himalaya. HMG/UNDP Mineral Exploration Project Report' (unpublished). $86 \mathrm{p}$.

Tokuoka, T. and Yoshida, M. (1984): Some characteristics of the Siwalik (Churia) group in the Chitwan Dun, central Nepal. Jour. Nepal. Geol. Soc., 4, Special Issue, 63-72.

UPRETI, B. N. and MERH, S. S. (1978): Geology of the area around Bhoksing-Sirkang section of the Kali Gandaki valley in Central West Nepal. Himalayan Geology, 8, (II), 797-812.

, Shringarpura, D. M. and MERH, S. S. (1980-a): Stromatolites from the Kali Gandaki Valley section, Central West Nepal: Their age, correlation and palaeoenvironmental interpretations. Geol. Surv. India. Miscellaneous Publ., 44, 253-266.

, Sharma, T. and MERH, S. S. (1980-b) : Structural Geology of Kusma-Sirkang section of the Kali Gandaki valley and its bearing on the tectonic framework of Nepal Himalaya. Tectonophysics, 62, 155-164.

VALDIYA, K. S. (1969): Stromatolites of the Lesser Himalayan carbonate formations and Vindhyans. Jour. Geol. Soc. Ind., 10, 1-25.

(1980-a): Geology of Kumaon Lesser Himalaya. Wadia Institute of Himalayan Geology, Dehra Dun, India, $291 \mathrm{p}$.

(1980-b) : Stratigraphic scheme of the sedimentary units of the Kumaun Lesser Himalaya. In: VAldiYA, K. S. and Bhatia, S. B. (eds.), Stratigraphy and Correlations of Lesser Himalayan Formations. Hindustan Publ. Delhi, 1-48. (1980-c) : Lesser Himalayan Stromatolites-their biostratigraphic implications. In: Stromatolites, Geol. Surv. India, Miscellaneous Publ., 44, 117-127.

Walter, M. R., (ed.), (1976): Stromatolites. Development of Sedimentology, 20, Elsevier, Amsterdam, 790 p. 